\title{
BIOLOGIA DE Rolepa unimoda (DOGNIN, 1923) (LEPIDOPTERA, LYMANTRIIDAE) EM FOLHAS DE Tabebuia avellanedae LOR, EX-GRISEB (BIGNONIACEAE) E OBSERVAÇÕES SOBRE SEUS INIMIGOS NATURAIS
}

\section{OTÂVIO PERES FILHO}

(Engenheiro Florestal)

Orientador : EVONEO BERTI FILHO

Dissertação apresentada à Escola Superior de Agricultura "Luiz de Queiroz", da Universidade de São Paulo, para obtenção do título de Mestre em Ciências Biológicas. Área de concentração: Entomologia.

$P|R A C| C A B A$

Estado de São Paulo - Brasil

Noyembro - 1983 
. ii.

\section{OFEREÇO}

Aos Engenheiros Florestais que lutam incansavelmente no ramo de Entomologia Florestal.

DEDICO

Aos meus pais por tudo que me ensinaram 


\section{AGRADECIMENTOS}

Ao Engenheiro Florestal Alberto Dorval, pelos inestimáveis auxílios prestados na execução deste trabalho.

Ao Livre Docente do Departamento de Entomolgia da. ESALQ/USP, Dr. Evoneo Berti Filho, pela compreensão, orientação e incentivo.

A Laboratorista, Carmem Silva Pesarini de Moraes, da Seção de Entomologia (CCA) da FUFMT, pelos auxilios nos trabalhos de laboratório.

Aos Especialistas Dr. Victor O. Becker pela identificação do le pidóptero, Dr. José Henrique Guimarães pela identificação do taquiní deo e Dr. Lauro Travassos Filho pela Literatura fornecida, pertinente ao lepidóptero estudado.

Aos Professores do Departamento de Engenharia Florestal (CCA) da FUFMT, MS. Zenesio Finger e MS. Ary Teixeira de Oliveira Fi Iho (identificação das espécies arbóreas), MS. Antonio Carlos Nogueira (fotografias) e MS. Norman de Barros Logsdon (análises).

Ao Professor Sérgio Batista Alves, do Departamento de Entomolo gia da ESALQ/USP, pela identificação do fungo entomógeno.

Ao Ex-Professor da Seção de Entomologia da UFMT, MS. Clayton Campanhola, pelos constantes incentivos e auxilios, que mui to ajudaram na realização deste trabalho. 


\section{INDICE}

Página.

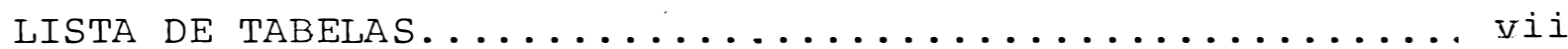

LISTA DE FIGURAS........................

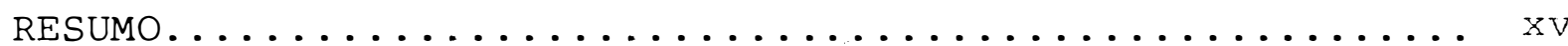

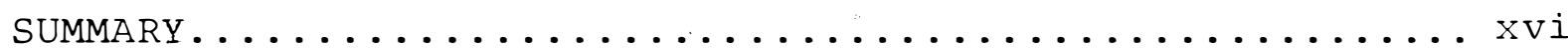

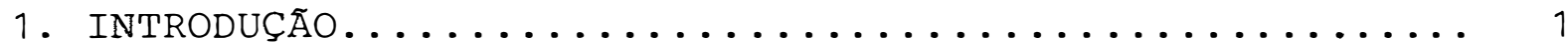

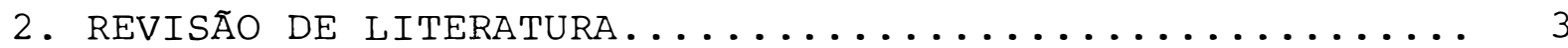

2.1. Posição Sistemática.................... 3

2.2. Importāncia Econômica da Família Lymantriidae.... . 3

2.3. Distribuição Geográfica do Gēnero Tabebuia....... 4 ×

2.4. Importância Econômica dos Hospedeiros de R. unimo-

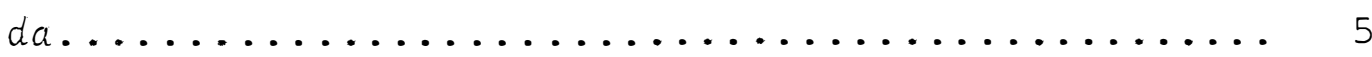

3. MATERIAL E METOdOS....................... 6

3.1. Instalações e Equipamentos................ 6

3.2. Coleta do Material..................... 8

3.3. Alimentação........................ 8

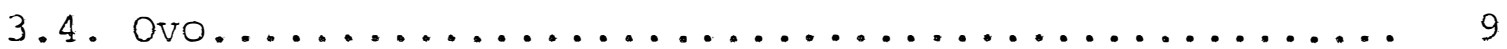

3.5. Lagarta.......................... 9

3.5.1. Criação de manutenção.............. 10

3.5.2. Nümero de instares................... 10

3.5.3. Área foliar consumida................ 11

3.5.4. Sobrevivência em jejum.............. 11

3.5.5. Viabilidade.................... 12 
Página.

3.5.6. Comportamento-................... 13

3.5.7. Caracterizáção morfológica...............13

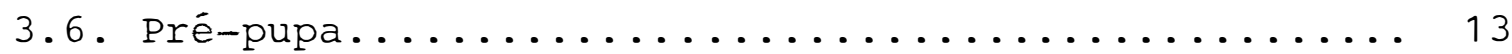

3.7. Рupa........................... 14

3.8. Adulto........................... 14

3.8.1. Emergência.................... 14

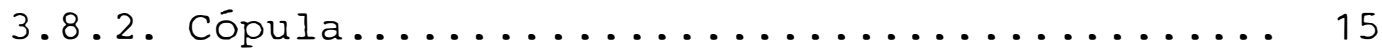

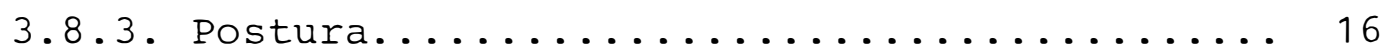

3.8 .4 Longevidade.................... 16

3.8.5. Comportamento................... 16

3.8.6. Caracterização morfológica............ 17

3.9. Inimigos Naturais.................... 17

3.10. Ilustrações........................ 17

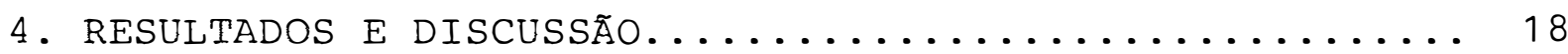

4.1. Características da Infestação e Ocorrência....... 18

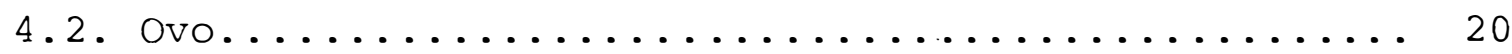

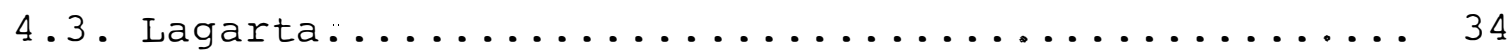

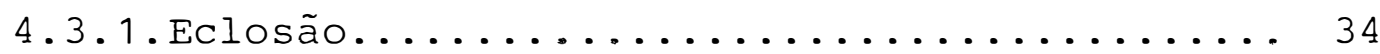

4.3.2. Número de instares................ 34

4.3.3. Duração dos instares............... 36

4.3.4. Duração do período larval............. 39

4.3.5. Largura da cápsula cefálica............ 40

4.3.6. Razão de crescimento da cápsula cefálica... 43

4.3.7. Área foliar consumida............... 43 
Página.

4.3 .8 . Sobrevivência ao jejum..............49

4.3.9. Viabilidade..................... 52

4.3 .10$. Caracterização dos instares........... 53

4.3 .11$. Comportamento.................... 62

4.4. Pré-pupa.......................... 64

4.5. Рupa........................... 68

4.6. Adulto............................ 75

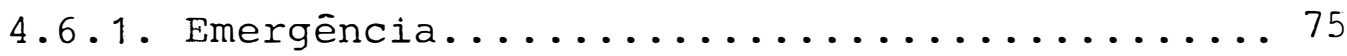

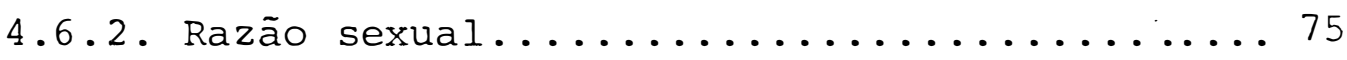

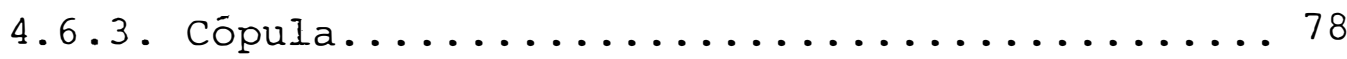

4.6 .4$. Postura....................... 82

4.6 .5 . Longevidade................... 88

4.6.6. Caracterização morfológica............. 90

4.6.7. Comportamento....................96

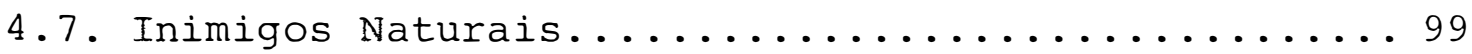

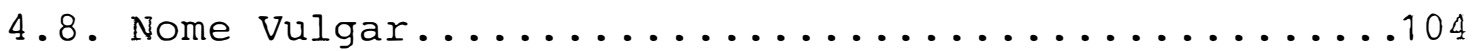

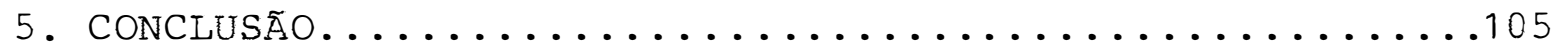

6. IITERATURA CITADA.............................. 


\section{LISTA DE TABELAS}

Tabela

Página.

1 Dimensōes de ovos recém-colocados por diferentes fêmeas de $R$. unimoda, Cuiabá, MT,

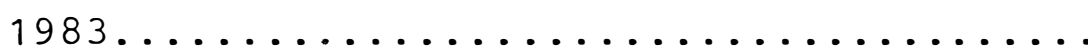

2 Quantidade de ovos depositados, por fêmeas copuladas de R. unimoda, Cuiabá, MT, 1983....

3 Quantidade de óvulos retidos no interior do abdome de fêmeas mortas de $R$. unimoda, Cuia bá, MT, $1983 \ldots \ldots \ldots \ldots \ldots \ldots \ldots \ldots \ldots \ldots \ldots \ldots \ldots \ldots \ldots \ldots \ldots \ldots \ldots \ldots$

4 Viabilidade, em porcentagem, das quantidades totais de ovos depositados por fêmeas co puladas de R. unimoda, Cuiabá, MT, 1983....

5 Quantidade de ovos de $R$. unimoda por postura coletada em $T$. avellanedae, da alameda principal da Fundação Universidade Federal de Mato Grosso, Cuiabá, MT, 1983.........

Quantidade de ovos de $R$. unimoda e respecti va viabilidade em posturas coletadas em $T$. avellanedae, da alameda principal da Fundação Universidade Federal de Mato Grosso,

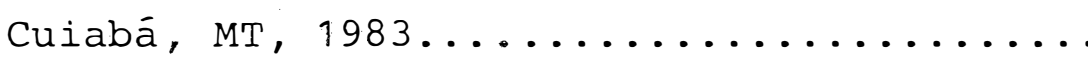

7 Quantidade de ovos de $R$. unimoda não parasi tados e férteis, com a respectiva viabilida de em posturas coletadas em $T$. avellanedae. na alameda principal da Fundação Universidá de Federal de Mato Grosso, Cuiabá, MT, 1983.. 
8 Duração, em dias, do período de incubação dos ovos de $R$. unimoda, obtidos de 28 postu

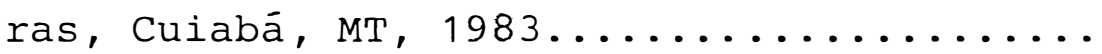

Duração média, em dias, de cada instar larval de $R$. unimoda, segundo o número de instares e sexo das lagartas que originaram os adultos. Cuiabá, MT, 1983..............

10 Duração, em dias, do período larval de $R$. $\underline{u}$ nimoda, de acordo com o número de instares e o sexo das lagartas que originaram os adultos, Cuiabá, MT, 1983...............

11 Larguras médias, em milímetros, das cápsu las cefálicas dos instares larvais em $R$. Unimoda, de acordo com o número de instares e sexo das lagartas que originaram os adultos. Cuiabá, MT, 1983................

12 Razão de crescimento das cápsulas, dos instares larvais de $R$. unimoda, de acordo com - número de instares e sexo das lagartas que originaram os adultos. Cuiabá, MT, 1983....

13 Consumo foliar de T. avellanedae, em centí metros quadrados, por lagartas de $R$. unimoda, segundo o sexo e com 6 instares. Cuiabá

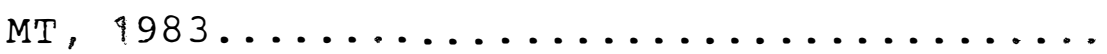

14 Consumo foliar de T. avellanedae, em centimetros quadrados, por lagartas de R. unimoda, segundo o sexo e com 7 instares

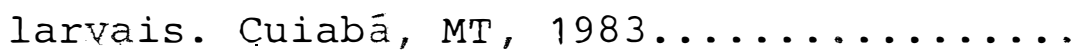


15 Duração média, em dias, do período de pré -pupa de R. unimoda. Cuiabá, MT, 1983.....

16 Comprimento e maior largura, em milímetros, de pupas de $R$. unimoda, segundo o sexo.Cüia

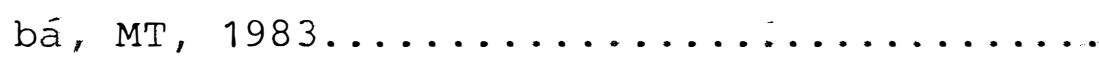

17 Peso, em gramas, de pupas recém-formadas de R. unimoda, segundo o sexo. Cuiabá, MT,

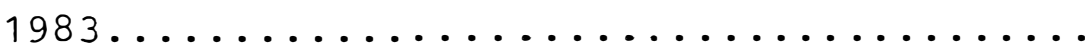

18 Duração média, em dias, do período pupal de R. unimoda, segundo o sexo das pupas. Cuia-

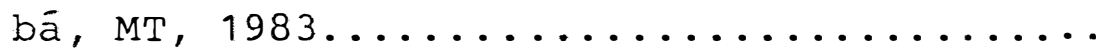

19 Quantidade de adultos emergidos de $R$. unimo da, de acordo com o horário e o sexo. Cuia-

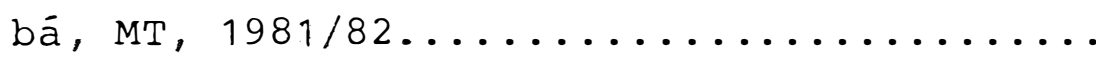

20 Duração, em dias do período de pré-cópula, em R. unimoda. Cuiabá, MT, 1983.........

21 Durações dos período de cópulas, em minutos obtidos de adultos de R. unimoda. Cuiabá,MT,

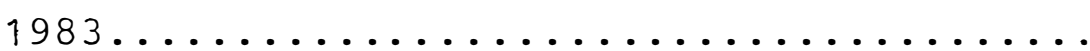

22 Duração, em dias, do período de pré-postura em R. unimoda. Cuiabá, MT, 1983.........

23 Duração, em dias, de período de postura em R. unimoda. Cuiabá, MT, 1983........... 
24 Duração," em dias, do período de pós-postura em fêmeas de R. unimoda, Cuiabá, MT, 1983...

25 Longevidade, em dias, de adultos fêmeas e machos de $R$. unimoda, acasalados e não acasa

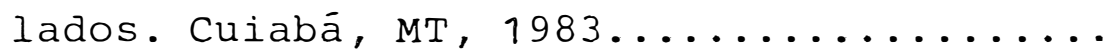

26 Envergadura, em milímetros, das asas ante riores de $R$. unimoda, de acordo com o sexo. Cuiabá, MT, 1981/82................ 


\section{LISTA DE FIGURAS}

Figura

Página.

1 Desfolhamento inicial, em uma árvores de Ta bebuia avellanedae, ocasionado por lagartas

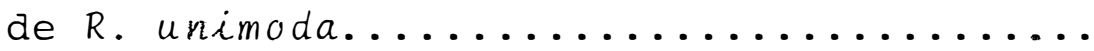

2 Um individuo de $T$. avellanedae com $100 \%$ da copa desfolhada, por lagartas de R. unimo-

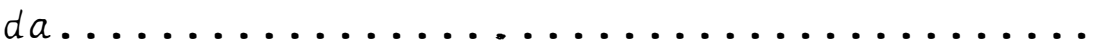

3 Ooplaca de R. unimoda, na parte ventral de uma folha de $T$. avellanedae (aumento 1,7 X)...

4 Período de incubação dos ovos de $R$. unimoda, conforme a quantidade e porcentagem dos indivíduos (total de 28 posturas), Cuiabá,

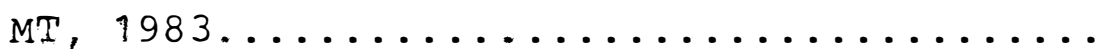

5 Números de ínstares do estágio larval de $R$. unimoda, de acordo com o sexo e a quantidade de lagartas e respectivas porcentagens (total de 40 lagartas), Cuiabá, MT, 1983...

Duração média e intervalo de confiança para cada instar e sexo das lagartas de $R$. unimo da, Cuiabá, MT, 1983................

7 Consumo IInstar, de acordo com o sexo, das lagartas com período larval de seis insta res, em R. unimoda, Cuiabá, MT, 1983......

8 Consumo Instar, de acordo com o sexo, das la gartas com período larval de sete instares, em R. unimoda, Cuiabá, MT, 1983.......... 
9 Sobrevivência acumulada, em porcentagem, dos instares de $R$. unimoda, segundo 0 periodo de jejum forçado, Cuiabá, MT, 1983........ 50

Lagartas de $R$. unimoda no primeiro instar.. (Aumento $25 \mathrm{X}$ )

Lagartas de $R$. unimoda no segundo instar... (Aumento 12X)

12 Lagartas de $R$. unimoda no terceiro instar.. (Aumento 12X)

Lagartas de $R$. unimoda no sétimo instar.... (Aumento 1,35X)

14 Lagartas de $R$. unimoda no oitavo instar.... (Aumento 1,15X)

15 Período de pré-pupa de R. unimodq conforme a porcentagem e com a respectiva quantidade de individuos (total de 244 pré-pupas). Cuia

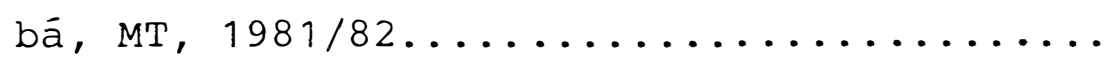

16 Frequências de emergência dos adultos de $R$. unimoda, em porcentagem, de acordo com o ho rário e o sexo (total de 30 indivíduos para cada sexol. Cuiabá, MT, 1981/82..........

17 Periodo de pré-cópula de $R$. unimoda, confor me a quantidade e porcentagem dos individuos (total de 31 fêmeas). Cuiabá, MT, 1983...

18 Periodo de pré-postura das fêmeas de $R$. uni moda, conforme a quantidade e porcentagem dos individuos (total de 33 fêmeas). Cuiabá

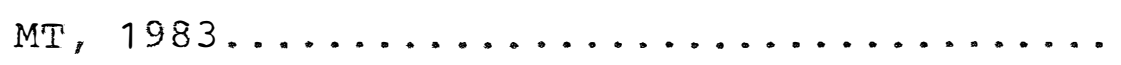


19 Período de postura de $R$. unimoda, conforme a quantidade e porcentagem dos individuos (total de 33 fêmeas). Cuiabá, MT, 1983....

20 Quantidade de posturas efetuadas por fêmeas de $R$, unimoda, com as respectivas quan tidades de fêmeas e porcentagens (total de 33 fêmeas). Cưiabà, MT, $1983 \ldots \ldots \ldots \ldots \ldots \ldots$

21 Período de pós-postura das fémeas de R. uni moda, conforme a quantidade e porcentagem

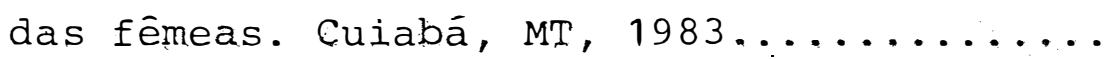

22 Adultos fêmeas (superior) e macho (inferior)

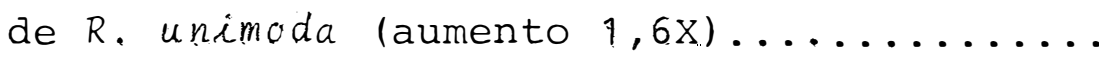
Parte terminal do abdome de um adulto (ma cho) de R. unimoda (aumento 25x) ..........

24 Parte terminal do abdome de um adulto (fee mea) de R. unimoda (aumento 12x).........

Massa de ovos de R. unimoda, coletada na alameda e parasitada por Telenomus sp. (a mento $1,7 x) \ldots \ldots \ldots \ldots \ldots \ldots \ldots \ldots \ldots \ldots \ldots \ldots \ldots \ldots \ldots$

26 Massa de ovos de $R$. unimoda, mostrando os parasitos Telenomus $\mathrm{sp}$. no ato da emergência (aumento $12 x) \ldots \ldots \ldots \ldots \ldots \ldots \ldots \ldots \ldots$

27 Um parasito de ovos (Telenomus sp. ) emer gindo do ovo de $R$. unimoda (aumento de 50x)..

28 Sintoma de ataque do fungo Verticillium sp. em uma lagarta de $R$. unimoda (aumento 12X).. 
Pupa (esquerda) e pré-pupa (direita) de $R$. unimoda, atacadas pelo fungo Verticillium sp. (tamanho natural)............... Um taquinideo adulto Archytas lopesi Guimarães parasito de lagartas de $R$. unimoda la mento $1,2 x) \ldots \ldots \ldots \ldots \ldots \ldots \ldots \ldots \ldots$ 
BIOLOGIA DE Rolepa unimoda (DOGNIN, 1923)

(LEPIDOPTERA, LYMANTRIIDAE) EM FOLHAS DE

Tabebuia avellanedaé LOR. EX-GRISEB (BIGNONIACEAE)

E OBSERWACÕES SOBRE SEUS IMIMIGOS NATURAIS

\author{
AUTOR: OTÁVIO PERES FILHO \\ ORIENTADOR: EVONEO BERTI FILHO
}

\title{
RESUMIO
}

Este trabalho trata do estudo da biologia de Rolepa unimoda (Dognin, 1923) (Lepidoptera, Lymantriidae), cujas lagartas são desfolhadoras em plantios omamentais de Tabebuia avel. lanedae Ior. ex-Griseb (Bignoniaceae). Ataca tambén T. caraiba (Mart.) Burm. Os insetos foram criados em conäições de laboratório (tempera tura $27 \pm 2^{\circ} \mathrm{C}$; UR $70 \pm 15 \%$, fotoperíodo de $12 \mathrm{~h}$ ), na seção de Entomologia do Centro de Ciências Agrárias da Fundação Universi dade Federal de Mato Grosso, em Cuiabá, MT. Foram estudados os seguintes parāmetros: período e viabilidade das fases de ovo, la garta, pré-pupa e pupa; número e duração dos instares larvais e consumo foliar da fase de lagarta; longevidade dos adultos e proporção quanto ao sexo; inimigos naturais; plantas hospedei ras e ocorrência do inseto nos Estados de Mato Grosso e Mato Grosso do sul. 


\title{
BIOLOGY OF Rolepa unimoda (DOGNIN, 1923) \\ (LEPIDOPTERA, LYMANTRI IDAE) ON LEAVES OF \\ Tabebuia avellanedae LOR. EX-GRISEB (BIGNONIACEAE) \\ AND OBSERVATIOHS ON ITS NATURAL ENEMIES
}

\author{
AUTHOR: OTÁVIO PERES FILHO \\ ADVISER: EVONEO BERTI FILHO
}

\section{SUMMARY}

This research deals with the study of the biology of Rolepa unimoda (Dognin,...1923) (Lepidoptera, Lymantriidae) whose larvae are defoliators on ornamental plantings of Tabebuia avellanedae Lor. ex-Griseb (Bignoniaceae). They also attack T.caraiba (Mart.) Burmeister. The insects were reared in laboratory conditions (Tempera-

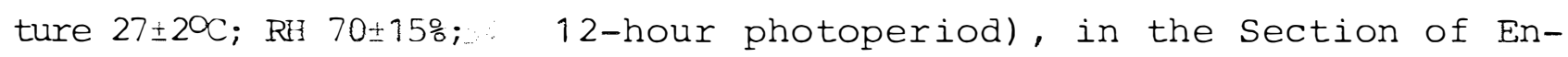
tomology, Center of Agricultural Sciences, Federal University of Mato Grosso, in Cuiabá, State of Mato Grosso, Brazil. The following parameters were determined: period and viability of the egg, larva, prepupa and pupa stages; number and length of the larval instars and leaf consumption of the larval stage; adult longevity and sex ratio; natural enemies; host plants and ocurrence of the insect in the States of Mato Grosso and Mato Grosso do sul. 


\section{INTRODUÇÃO}

A implantação de monoculturas florestais de espécies exóticas no Brasil trouxe, como conseqüência, um direcionamento da pesquisa entomológica florestal, voltado para es sas culturas. Pode-se constatar que praticamente não existem in formações entomológicas sobre as espécies nativas usadas no re florestamento ou no paisagismo. Quanto à importância das espécies nativas, muitas delas são amplamente empregadas em atribuições das mais variadas. O problema para a avaliação correta da quantificação do uso dessas espécies reside na falta de levantamentos que poderiam ser efetuados nas serrarias localizados nas zonas de exploração natural.

Por outro lado, algumas dessas espécies nativas podem assumir tanto um papel importante sob o ponto de vista madeireiro, como também sob o ponto de vista paisagistico e me dicinal, como ocorre com o grande grupo dos ipês (Tabebuia spp.), 
apreciadissimos pela madeira e como ornamentais, em virtude das maciças florações vivamente coloridas, na ausēncia da folhagem após a floração (RIZZINI, 1971). Contudo, os ipēs não são cul. tivados comercialmente, como se faz com Tabebuia avellanedae. Lor. ex-Griseb, na região do Chaco Argentino (FLINTA, 1977).

Sob o ponto de vista paisagístico muitos fatores podem ser levados em consideração, tais como estética, por te, tipo de raízes e sombreamento, principalmente para as regiões muito quentes. T. avellanedae apresenta um crescimento lento (FLINTA, 1977), com as folhas caducas caindo em sua quase totalidade nas épocas secas e só apresentando uma copa de boa conformação na época chuvosa. A ação de insetos desfolhadores em T. avellanedae, acarreta sérios prejuízos para os objetivos propostos pelo paisagismo pois retarda o crescimento, que já é lento, além de eliminar o sombreamento nas épocas em que as folhas estão presentes.

Procurando trazer subsídios para a proteção da espécie T. avellanedae, de grande valor paisagístico, objetivou-se neste trabalho estudar alguns aspectos relacionados à biologia e ao comportamento de $R$. unimoda, importante desfolha dor de T. avellanedae. 


\section{REVISÃO DA LITERATURA}

\subsection{POSIĆ̃̃o SISTEMÁTICA}

\subsection{IMPORTÂNCIA ECONÔMICA DA FAMÍLIA LYMANTRIIDAE}

nome de Phiditia unimoda baseando-se em um exemplar macho, pro veniente de Santarém, PA (DOGNIN, 1923). Posteriormente teve seu gēnero transferido para Rolepa Walker (SCHAUS, 1927).

SILVA et alii (1968) registraram os limantriideos Sarsina violacens (Herrich-Schaeffer) em Eucalyptus spp., goiabeira e araçazeiro; Thagona sp. em folhas de algodoeiro e cajueiro e Phiditia cuprea Kaye em ipê. 
Thagona sp. foi citada como praga do cajueiro por GALLO et alii (1978).

BERTI FILHO (1981) assinalou S. violacens como praga de Eucalyptus alba, E. globulus e E. saligna.

\subsection{DISTRIBUICÃO GEOGRÁFICA DO GÊNERO Tabebuia}

O gênero Tabebuia comporta cerca de 60 espécies distribuidas na América tropical, desde o México até a Argentí na, sendo a maioria das espécies encontradas no Brasil (RIZZINI, 1971).

Tabebuia avellanedae é conhecida na Amazônia e Nordeste como pau-d'arco-roxo; no Rio Grande do Sul como ipê-roxo e ipê-preto, sendo abundante nos Estados do Pará, Ceará e Pernambuco; aparece também em Minas Gerais, Bahia e é bastan te comum no Pantanal de Mato Grosso com a denominação de piúva-roxa, ocorrendo, ainda, nos seguintes países da América do Sul: Argentina, Paraguai, Bolivia e Peru (RIZZINI, 1971). RATE et alii (1973) afirmaram que $T$. avellanedae ocorre em matas de galerias, provavelmente em solos mais ricos em nutrientes, segundo observações realizadas por uma expedição feita em Xavantina, MT. 


\subsection{IMPORTÂNCIA ECONÔMICA DOS HOSPEDEIROS DE $R$. unimoda:}

Conforme CORREA (1931), T. caraiba (Mart.) Burm. fornece madeiras para construção civil, obras internas, ripas, tamancos, curvas de selas, carpintaria, caixotaria e pasta para papel. Apresenta a casca amarga, com propriedades antipiréticas que já era usada pelos indios pré-colombianos, mas atual mente é mais empregada como depurativo e anti-sifilitico. Também tem valor como árvore ornamental.

Segundo CORREA (1969) T. avellanedae produz madeira rija e aproveitável para obras expostas; o decoto da cas ca é adstringente e mucilaginoso, tem emprego contra úlceras sifiliticas, apresentando as folhas a mesma propriedade, além de serem antiblenorrágicas; contêm ácido tānico e lápáchico, sais alcalinos e matéria corante de fácil extração, adequados para tingir seda e algodão com as cores amarela, cinza, rosa, alaranjada e castanha de acordo com a manipulação. 
.6 .

\section{MATERIAL E MÉTODOS}

\subsection{INSTALAČ̃ES E EQUIPAMENTOS}

Esta pesquisa foi desenvolvida na seção de Entô logia, do Centro de Ciências Agrárias, da Fundação Universidade Federal de Mato Grosso.

$$
\text { Utilizou-se para a realização do trabalho duas }
$$

salas, sendo uma delas destinada à criação das lagartas e a ou tra para a manutenção de ovos, pré-pupas, pupas e adultos. Em ambas as salas foram mantidas as condições de temperatura, umi dade relativa e fotoperiodo ( $27 \pm 20^{\circ} ; 70 \pm 15 \% ; 12$ horas). Todas as pesagens foram realizadas em uma balan ça de precisão, com capacidade máxima de 160 gramas.

Para a incubação dos ovos, bem como para as la- 
gartas usadas para as medições utilizou-se placas de petri com - fundo recoberto por papel toalha.

As pupas com 10 dias eram transportadas para as gaiolas de acasalamento, com 30 x 40 x $43 \mathrm{~cm}$, confeccionadas em madeira e filó branco nas laterais e no teto, possuindo o fundo de madeira recoberto de fórmica branca, com uma portinhola na frente. Essas gaiolas foram empregadas para todas as observações da fase adulta.

Para o teste de sobrevivência ao jejum empregou-se recipientes idênticos aos utilizados para as tomadas de medições das lagartas.

Nas manipulações dos ovos e lagartas empregou-se pincéis.

As medições Iineares das cápsulas cefálícas e as dimensões dos ovos foram obtidas com uma ocular micrométrica de tambor rotativo com divisões, acoplada a um microscópio estereoscópico binocular, de duzentos aumentos.

Nas medições das pupas (comprimento e maior lar gura) e adultos (envergadura), utilizou-se um paquímetro de cento e cinqüenta milimetros.

As placas de Petri e placas de cristalização fo ram esterilizadas em estufa, a $200^{\circ} \mathrm{C}$ por um período minimo de 60 minutos. 


\subsection{COLETA DO MATERIAL}

Foram coletados ovos, lagartas e pupas com a fi nalidade da obtenção dos dados biométricos. As coletas foram realizadas no 55 ipês da alameda principal da Fundação Universidade Federal de Mato Grosso e algumas coletas numa praça, am bas na capital de Mato Grosso, Cuiabá. A espécie de ipé dessas duas localidades é T. avellanedal.

Realizou-se também coletas de ovos e pupas em

T. caraiba, em região de cerrado, na capital de Mato Grosso do Sul (Campo Grande) com a finalidade de estabelecer-se a comparação das espécies nos dois locais, além da determinação do hos pedeiro vegetal nativo de Rolepa unimoda.

A primeira coleta foi realizada em março de 1980, mas somente em 1981 é que se iniciaram os estudos. A par tir desta última data mais de vinte coletas foram efetuadas com a finalidade de obter o material para estudo, além de manter o vigor dos individuos em laboratório.

\subsection{ALIMENTACÃO}

As lagartas foram alimentadas com folhas jovens de T. avellanedae, coletadas na alameda principal, da Fundação Universidade Federal de Mato Grosso. Escolheu-se as folhas jovens devido a avidez que as lagartas apresentaram por este tipo de folha. 


\section{4, Ovo}

Procurou-se observar as árvores das diferentes regiões, com a finalidade de detectar os locais de postura. Fo ram coletadas placas para a determinação da taxa de fertilidade, identificação dos possiveis inimigos naturais e quantifi cação dos ovos por placa.

Em laboratório os ovos foram retirados das gaio las diariamente, através de pincel sendo imediatamente transfe ridos para as placas de Petri. Quantificou-se os ovos por postura e o total depositado por fêmeas. Os abdomes das fêneas mor tas foram abertos, em placas de Petri com água, para a contagem dos óvulos retidos. Através das observações diárias pode- se determinar a quantidade de ovos por postura, as mudanças na coloração devido a maturação, o período de incubação e a via bilidade. Dos ovos provenientes da alameda, determinou-se a quantidade por postura e a respectiva viabilidade.

\subsection{LAGARTA}

As medições foram feitas no inicio com cem lagartas individualizadas, provenientes dos ovos de cinco fēmeas, medindo-se portanto vinte individuos para cada fēmea. As folhas eram trocadas duas vezes ao dia, sendo fornecidas intei ras, sem o pedúnculo. A limpeza das placas de Petri era reali- 
zada diariamente sendo o papel toalha trocado a cada limpeza e com algodão embebido em álcool 98\%, procurou-se esterilizar es tes recipientes.

\subsubsection{CRIAÇÃO DE MANUTENÇÃO}

As lagartas coletadas no campo, bem como os ovos da alameda proveniente desse material eram colocados em cubas de vidro. A parte superior desses recipientes era coberta de plástico perfurado, a fim de impedir uma dessecação maior das folhas. As folhas eram trocadas diariamente por folhas frescas e tenras, sendo a limpeza feita todos os dias, com a retirada das fezes e de lagartas contaminadas por fungo. Dessa criação obtiveram-se os individuos adultos, que originaram as gerações estudadas em laboratório. Sendo assim preocupou-se em fazer co letas constantes, com a finalidade de manter-se sempre gerações vigorosas em laboratório.

\subsubsection{NÚMERO DE INSTARES}

Para a determinação do nümero de İnstares, fez- se as medições das cápsulas cefálicas, em sua maior largura. Determinou-se a razão de crescimento das cápsulas e a respecti va média geral. 


\subsection{3. ÁREA FOLIAR CONSUMIDA}

As folhas, antes de serem colocadas nas placas de Petri, tiveram seus contornos desenhados em uma folha de pa pel e posteriormente forneciaas às lagartas. Por diferença de área, processou-se os desenhos das partes comidas. As folhás, quando colhidas, eram desenhadas rapidamente para evitar uma maior perda de umidade, sendo inclusive utilizadosisacos plástí cos para o transporte das folhas das árvores para o laborató rio. A determinação da área foliar, consumida por lagarta, foi baseado na relação peso/área do papel.

\subsection{4, SOBREVIVÊNCIA EM JEJUM}

Para o teste de mortalidade das lagartas em jejum, analisou-se os três primeiros instares. A finalidade desse teste foi de determinar a capacidade de sobrevivência das lagartas, nos casos de busca de novas fontes de alimentos. Utilizou-se 100 lagartas para cada um dos instares, sendo que para o primeiro instar empregou-se lagartas recém-eclodidas e, portanto, sem nenhuma alimentação prévia. No teste das lagar- 
tas do segundo instar, utilizou-se lagartas que tinham sofrido a primeira ecdise recentemente e alimentadas no primeiro instar, sendo de 3 dias a idade das lagartas. No teste das lagartas do terceiro instar, usou-se as lagartas que tinham sofrido a segunda ecdise recentemente e alimentadas nos dois primeiros instares. A idade das lagartas para esse teste foi de seis dias. As contagens das lagartas mortas foram realizadas a cada doze horas e, entre esses periodos de tempo fez-se observações freqüentes.

Para a verificação da morte dos indivíduos utilizou-se pincel no 2 e com toques leves no corpo das lagartas, procurou-se perceber o menor movimento possivel, sendo que tal constatação foi feita na lupa.

Todo o teste foi feito em placas de Petri, sendo que para cada instar utilizou-se dez placas de Petri, com dez lagartas em cada uma delas. Forneceu-se folhas tenras e in teiras para as lagartas como alimentação prévia.

\subsubsection{VIABILIDADE}

Dos cinco lotes de lagartas anotou-se a mortalidade em cada instar e a mortalidade de todas as lagartas estuda 
das, visando-se determinar a viabilidade de sobrevivência .em cada instar e a viabilidade de sobrevivência de todas as lagar tas.

\section{5,6. COMPORTAMENTO}

Observou-se o comportamento das lagartas provenientes da alameda e em laboratório, objetivando-se conhecer os hábitos de movimentação, repouso e alimentação.

\section{$3,5,7$, CARACTERIZAÇÃO MORFOLÓG I CA}

Os instares larvais foram descritos e ilustra dos através de fotografias.

3.6. PRÉ-PUPA

As pré-pupas foram observadas diariamente das 8:00 às 21:00 horas. As observaçōes tiveram como objetivo veri ficar o comportamento em laboratório, duração da fase, determi nação da viabilidade e fazer a descriçāo morfológica. 


\subsection{PUPA}

As pupas foram observadas diariamente, das 8:00 às 23:00 horas, procurando-se obter dados sobre a duração do período, viabilidade, comprimento, largura, peso no primeiro dia, mudança de coloração e características morfológicas, todos os demais itens foram determinados de acordo com o sexo. No caso da pesagem, as pupas foram isoladas individualmente em pla cas de cristalização. Observou-se, também, a sua acómodação nos recipientes de laboratório.

Fez-se a sexagem do material de laboratório e dos plantios, com a finalidade de se calcular a proporção sexual.

3.8. ADULTO

Os adultos foram observados em laboratório e no campo .

\subsubsection{EMERGÊNCIA}

Para a determinação do horário de emergência dos 
adultos, foram utilizadas pupas coletadas na alameda. As pupas trazidas para laboratório foram sexadas e separadas individual mente, em placas de cristalização. Nas placas, as pupas foram encobertas por tiras de papel toalha. O periodo utilizado para as observações foi das 7:00 às 23:00 horas. Dessa forma, pôde-se estabelecer a relação sexo/hora de emergència. Como em todo o transcorrer do estudo, o fotoperíodo foi de 12:00 horas de luz.

\subsubsection{CÓPULA}

Inicialmente, utilizou-se as seguintes proporções sexuais: 1 macho : 1 fêmea; 2 machos : 1 fêmea; 3 machos: 1 fêmea e 4 machos : 1 fēmea em gaiolas de acasalamento de $30 \times 40 \times 43 \mathrm{~cm}$, mas devido ao fato da fémea ser monocárpica, op tou-se definitivamente para a proporção de 1 macho : 1 fèmea. Agrupou-se 35 casais, sendo que estes foram formados sempre por individuos emergidos no mesmo dia. A duração da cópula foi observada em 25 casais. O período de peré-copula e número de cópu las foram determinados para 32 casais, através das observações noturnas e a cada dez minutos. Para tal, empregou-se uma minilanterna de uma pilha (1,5 v), não sendo quebrado,portanto, o fotoperíodo. 


\section{$3,8,3$, POSTURA}

Dos 35 casais agrupados, observou-se o número de postura feita por 26 fêmeas. Os períodos de pré-postura, postura e pós-postura foram observados em 33 fêmeas. Determinou- se, também, a viabilidade dos ovos obtidos dessas fêmeas de laboratório e dos ovos trazidos do campo.

\section{$3,8,4$, LONGEVIDADE}

$\mathrm{Na}$ determinação da longevidade coletou-se infor mações de 30 casais copulados e 30 fêmeas e 30 machos não copulados, procurando-se assim verificar a iñfluência do acasala mento na longevidade dos indivíduos. Para o cálculo da longevi dade, os individuos foram observados diariamente. Para a determinação do estado de morte utilizou-se o toque de pincel, a fim de verificar se havia algum movimento por parte do individuo. Esses toques eram repetidos após alguns minutos, para assegurar a verificação da morte.

\subsubsection{COMPORTAMENTO}

Estudou-se o comportamento dos adultos, levando-se em consideração observações diurnas e noturnas dos indi- 
víduos de laboratório. No campo os adultos foram observados so mente durante o dia. Objetivou-se conhecer o ritual de cópula, vōo e repouso, alimentação e hábitos de posturas.

\section{8,6. CARACTERIZACÃO MORFOLÓGICA}

Descreveu-se a morfologia externa dos adultos, de ambos os sexos. Os individuos utilizados foram os de labora tório e os provenientes do campo. Mediu-se também as envergadū ras das asas anteriores de 32 machos e 32 fêmeas oriundas desses dois locais.

\subsection{INIMIGOS NATURAIS}

Observou-se os inimigos naturais, procurando-se coletar, identificar e estudar os parasitóides, predadores e patógenos em cada fase de desenvolvimento de $R$. unimoda.

\subsection{ILUSTRACÕES}

Procurou-se ilustrar através de gráficos, tabelas e fotografias as caracteristicas morfológicas, comportamen tos e particularidades ligadas a cada fase de desenvolvimento de $R$. unimoda em situações de laboratório e campo. 


\section{RESULTADOS E DISCUSSÃO}

\subsection{CARACTERÍSTICAS DA INFESTACÃO E OCORRENCIA}

A presença de $R$. unimoda foi notada durante $O$ a no todo sendo, porém, muito mais intensa nos meses de chuva, que na região cuiabana vai de novembro a março, e ainda no mês de abril, diminuindo gradativamente posteriormente. Na ocasião dos meses secos, quando as árvores de ipé perdem suas follhas, pouquissimas lagartas foram encontradas nas folhas ainda presentes.

A população de $R$. unimoda apresenta gerações su perpostas, encontrando-se ovos, lagartas, pupas de adultos simultaneamente em qualquer época do ano.

o sintoma de ataque foi facilmente observado, pois o inicio deu-se pelas extremidades dos ramos de toda a copa (Fig. 1). Os danos começaram pelas folhas mais tenras dos pon- 


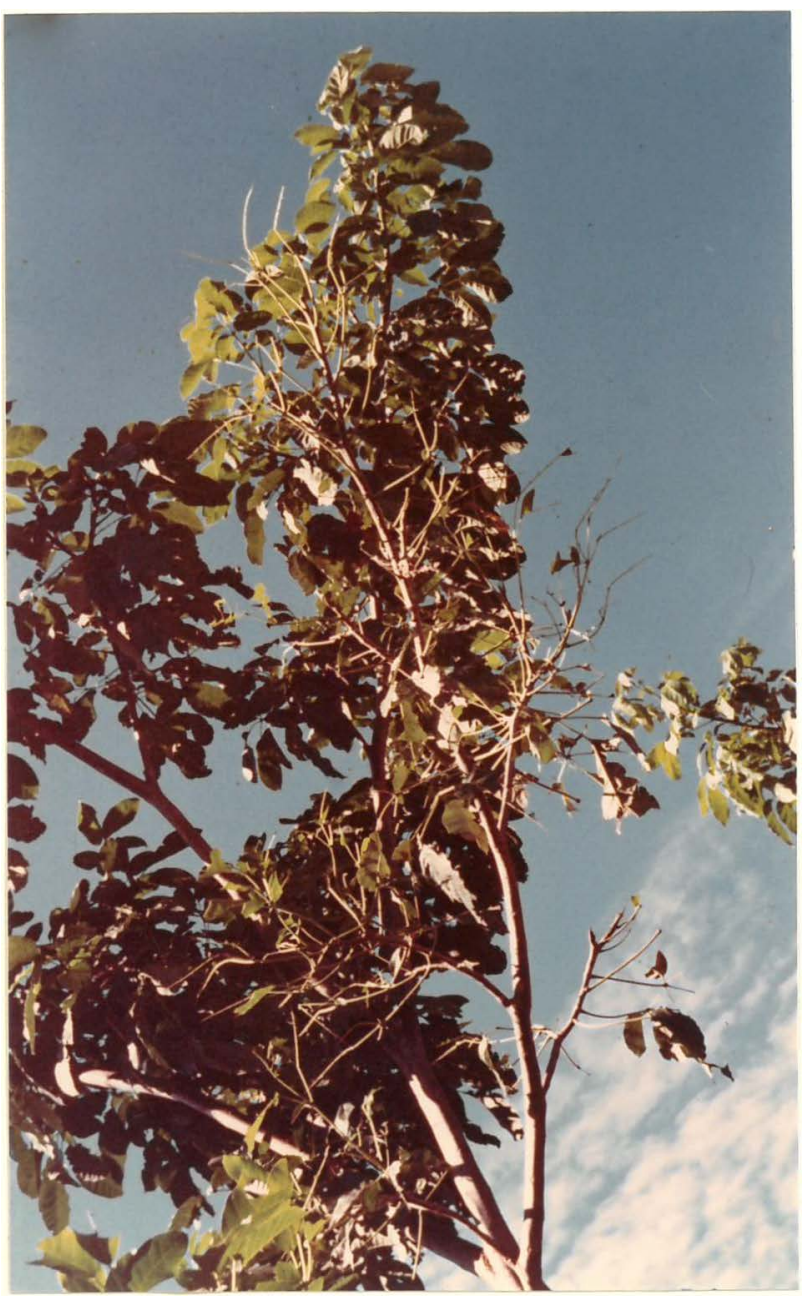

Figura 1 - Desfolhamento inicial, em uma árvore de Tabebuia avella nedae, ocasionado por lagartas de $R$. unimuda.

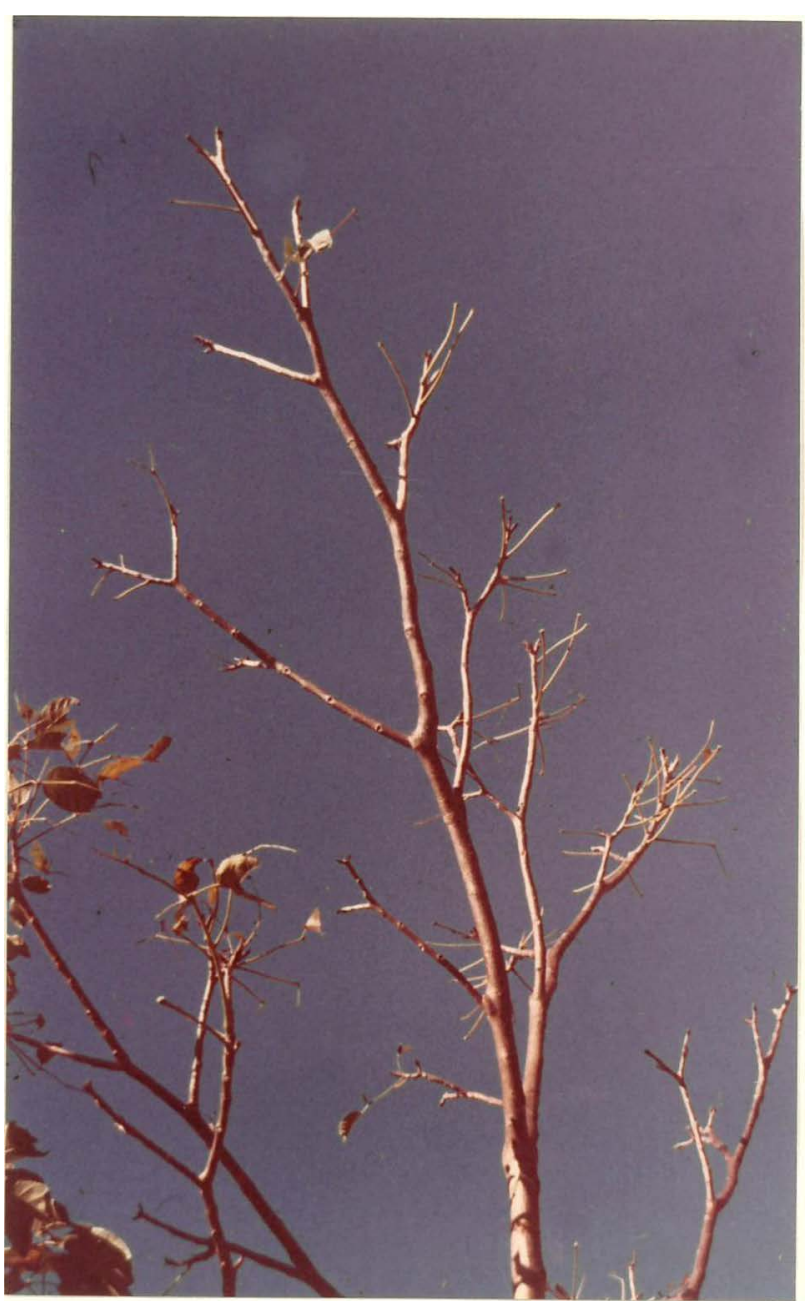

Fioura 2 - Um indivíđuo de Tabebuia avellanedae com 100\% da copa desfolhada por lagartas de R. unimoda. 
teiros e, à medida que as lagartas se desenvolviam os danos propagaram-se para todo o restante da copa. Logo no início do ataque foram notadas as folhas dos ponteiros com a epiderme inferior raspada.

Algumas ärvores foram mais atacadas do que outras, mas nenhuma escapou da ação das lagartas, sendo que os danos produzidos em alguns individuos chegou a atingir 100\% de desfolhamento (Fig. 2). Quando o desfolhamento foi total, .... as lagartas passavam para as árvores vizinhas. Tal ação era feita em agrupamentos, onde se notou grande fileiras de lagartas des cendo pelos ramos e troncos das árvores.

Alēm da espécie ornamental plantada na alameda principal do Campus, T. avellanedae (ipê-rosa), as lagartas de R. unim da também produziram severos danos em alguns indivíduos de Tabebuia caraiba (paratudo) plantados no campus e que também ocorrem no cerrado e pantanal matogrossenses.

Pupas de $R$. unimoda também foram coletadas em paratudo (T. caraiba) provenientes de uma região de cerrado em Campo Grande, capital do Mato Grosso do Sul e, ainda nesta espê cie vegetal, foram coletados ovos e lagartas nas folhas, ocor rendo em regiões de cerrado em Cuiabá, MT.

\subsection{Ovo}

observou-se que, em laboratório, os ovos foram co- 
locados nas guarniçōes e telas de filó das gaiolas. Raramente foram encontrados nas folhas de ipé e nunca nas cascas, fornecidas experimentalmente.

No campo foram encontrados aderidos na pägina in ferior das folhas de ipé, formando ooplacas e somente uma vez foi observada uma ooplaca no fuste.

Em laboratório os ovos foram colocados desorganizadamente, encontrando-se ovos isolados ou formando pequenos agrupamentos, sendo também notado algumas ooplacas sobre as guarnições de madeira da gaiola. Assim como as ooplacas, for mações acinosas foram bastante raras.

A remoção dos ovos aderidos aos substratos foi feita sem dificuldades.

os ovos recém-colocados apresentam inicialmen te uma coloração verde-limão com tonalidade clara e, ainda no primeiro dia, nota-se um leve escurecimento. No segundo dia tornam-se vinho claros, tendo ao centro uma mancha verde limão, que em alguns ovos restringem-se ao tamanho de um pequeno ponto. A coloração no terceiro dia é semelhante a do dia anterior, notando-se o aparecimento da micröpila na parte superior. No quarto dia nenhuma alteração é observada, embora quase todos os ovos apresentem a coloração vinho (Fig. 3). No quinto dia as áreas de coloração verde-limão não se alteram, porém as regiōes de coloração vinho sofrem um clareamento e com surgimento de fijamentos de cor vinho escura, dispostos irregularmante por todo o ovo. No sexto dia a coloração vinho clara passa pa- 


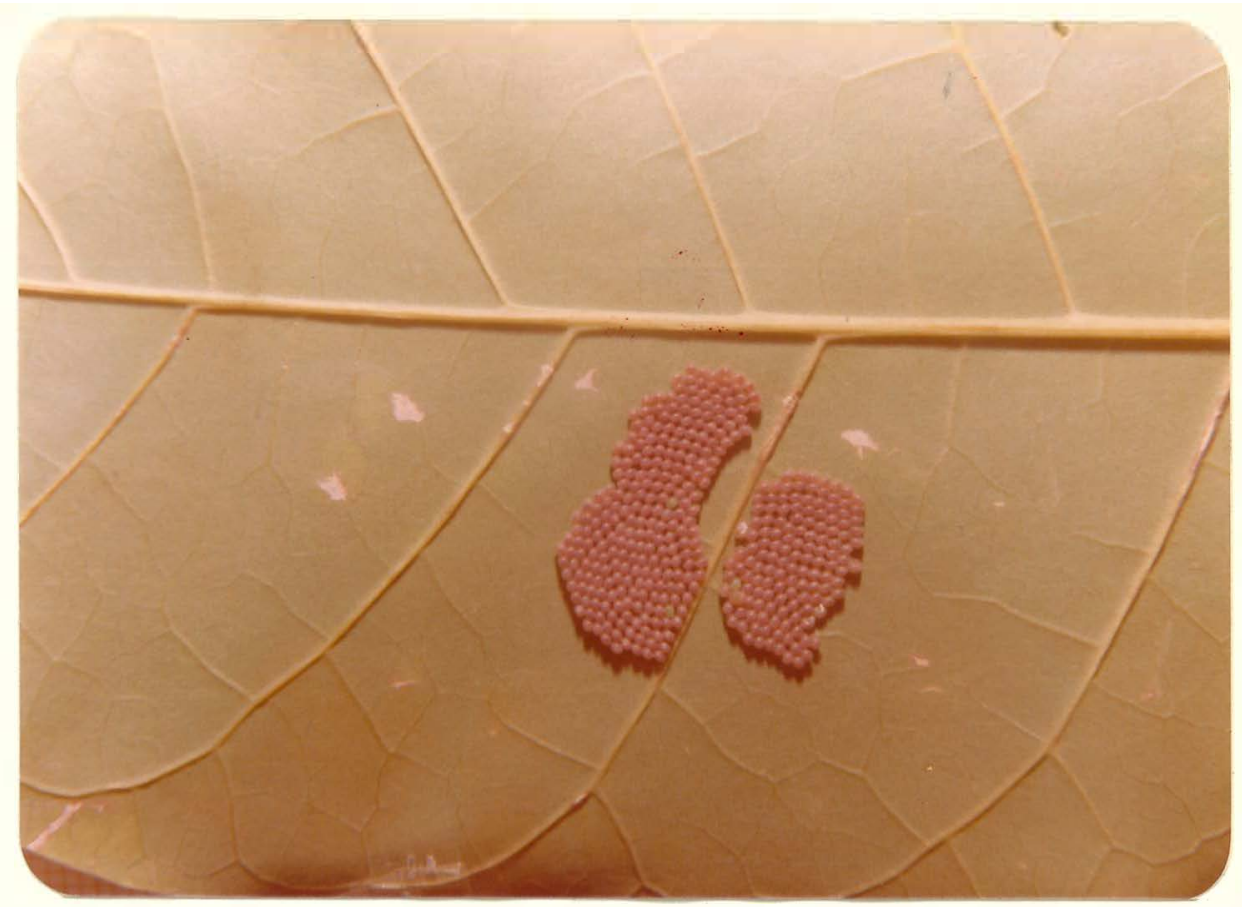

Figura 3 - Ooplaca de R. unimoda, na parte ventral de uma folha de T. avel lanedae (aumento $1,7 \mathrm{x}$ ).

ra uma coloração amarelo-palha, com regiōes mais escuras; observa-se, também, as contrações do vaso dorsal da lagarta no in terior do ovo. No sétimo dia ocorre a eclosão das lagartinhas. O córion dos ovos apresenta pequenas pontuações visiveis somente sob lupa. Forma geral ovalada, com um pequeno achatamento nos extremos e mais acentuado nas laterais.

\section{Nas determinações das dimensões, foram obtidos} os valores unitários médios de 20 ovos/fēmea, e de cinco fēmeas, sendo que para a largura máxima o valor foi de 0,892 mm, para a largura mínima de 0,554 m e para o comprimento 1,195 m (Tabela 1). 
Tabela 1 - Dimensões de ovos recém-colocados por diferentes fémeas de R. unimoda, Cuiabá, MT, 1983.

\begin{tabular}{cccc}
\hline $\begin{array}{c}\text { Fërneas } \\
\text { (no de ovos) }\end{array}$ & $\begin{array}{c}\text { Largura máxirná } \\
\text { média (mm) }\end{array}$ & $\begin{array}{r}\text { Largura minima } \\
\text { média (mm) }\end{array}$ & $\begin{array}{c}\text { Comprimento } \\
\text { médio (m) }\end{array}$ \\
\hline $1(20)$ & 0,886 & 0,507 & 1,156 \\
$2(20)$ & 0,888 & 0,558 & 1,212 \\
$3(20)$ & 0,885 & 0,579 & 1,216 \\
$4(20)$ & 0,908 & 0,525 & 1,195 \\
$5(20)$ & 0,893 & 0,603 & 1,194 \\
Méäia & 0,892 & 0,554 & 1,195 \\
IC & $0,892 \pm 0,012$ & $0,554 \pm 0,049$ & $1,195 \pm 0,029$ \\
\hline
\end{tabular}

Em laboratório, a quantidade de ovos depositados pelas 33 fêmeas observadas variou de um mínimo de 10 ovos

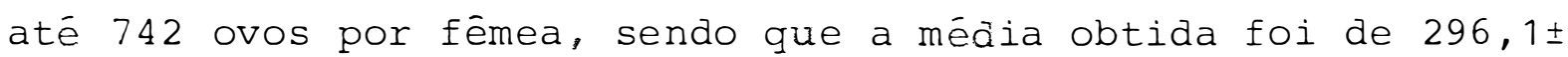
54,3 ovos por fêmea (Tabela 2).

Da contagem dos óvulos retidos no abdome de 31 fêmeas a média obtida foi de $88,7 \pm 48,3$ óvulos por fémea, sen do que a variação encontrada foi de zero (5 individuos), até 611 óvulos (Tabela 3).

Não houve efeito de regressão linear simples en tre a quantidade de ovos depositados por fémea e a respectiva quantidade de óvulos retidos no abdome, pois obteve-se um coeficiente de correlação não significativo. 
Tabela 2 - Quantidade de ovos depositados, por fêneas copuladas de $R$. unímoda, Cuiabá, MP, 1983.

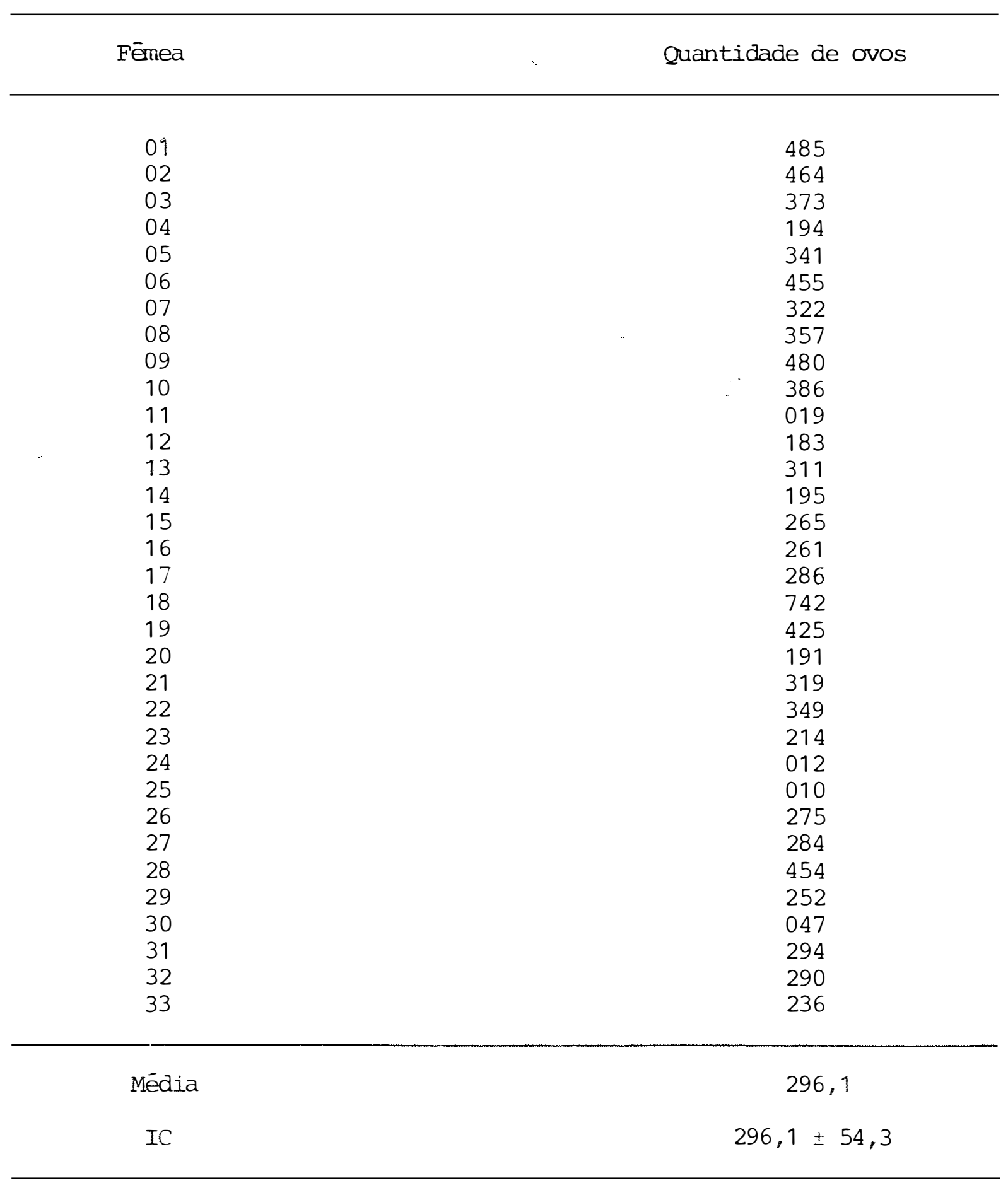


Tabela 3 - Quantidade de óvulos retidos no interior do abdane de fêmeas mor tas de R. unimoda, Cuiabá, MT, 1983.

\begin{tabular}{|c|c|}
\hline Fênea & Quantidade de óvulos \\
\hline $\begin{array}{l}01 \\
02 \\
03 \\
04 \\
05 \\
06 \\
07 \\
08 \\
09 \\
10 \\
11 \\
12 \\
13 \\
14 \\
15 \\
16 \\
17 \\
18 \\
19 \\
20 \\
21 \\
22 \\
23 \\
24 \\
25 \\
26 \\
27 \\
28 \\
29 \\
30 \\
31\end{array}$ & $\begin{array}{r}0 \\
05 \\
36 \\
0 \\
0 \\
18 \\
06 \\
91 \\
198 \\
247 \\
611 \\
98 \\
0 \\
187 \\
62 \\
14 \\
54 \\
17 \\
32 \\
04 \\
51 \\
19 \\
152 \\
115 \\
239 \\
0 \\
342 \\
124 \\
15 \\
09 \\
05\end{array}$ \\
\hline Média & 88,7 \\
\hline IC & $88,7 \pm 48,3$ \\
\hline
\end{tabular}


Das 35 fémeas acasaladas, determinou-se a viabí Iidade média dos totais de ovos colocados por 23 fêmeas, sob condições de laboratório, obtendo-se 83,20\% de ovos viáveis (Ta bela 4).

Tabela 4 - Viabilidade, em parcentagern, das quantidades totais de ovos depositados por fêneas copuladas de R. unimoda, Cuiabá, MT, 1983.

\begin{tabular}{|c|c|}
\hline Fêmea & Viabilidade $\left(\frac{\circ}{0}\right)$ \\
\hline $\begin{array}{l}01 \\
02 \\
03 \\
04 \\
05 \\
06 \\
07 \\
08 \\
09 \\
10 \\
11 \\
12 \\
13 \\
14 \\
15 \\
16 \\
17 \\
18 \\
19 \\
20 \\
21 \\
22 \\
23\end{array}$ & $\begin{array}{l}90,10 \\
97,84 \\
91,42 \\
92,43 \\
51,29 \\
57,89 \\
92,89 \\
81,99 \\
90,76 \\
88,74 \\
90,80 \\
91,25 \\
88,27 \\
94,11 \\
80,11 \\
94,26 \\
13,02 \\
89,64 \\
87,69 \\
72,34 \\
91,49 \\
97,24 \\
88,13\end{array}$ \\
\hline Méāia & 83,20 \\
\hline$I C$ & $83,20 \pm 8,26$ \\
\hline
\end{tabular}


Para ovos coletados, a viabilidade média foi de 50,68\% (Tabela 6). Comparando-se os valores obtidos (Tabe las 4 e:6), observa-se que na segunda o valor foi bem menor pois, nas massas de ovos provenientes da alameda constataram 7 oopla cas parasitadas, 2 com ovos inférteis e 4 aparentando parasitismo e ovos inférteis. Sendo assim, foram separadas as viabilidades dos ovos da alameda, mas apenas com viabilidades não a fetadas pelo parasitismo, infertilidade ou ambas situaçōes simultaneamente, com a finalidade de se estabelecer a comparação com a viabilidade de laboratório. Dessa forma, obteve- se uma viabilidade média de 84,00\% (Tabela 7) que, comparada com a viabilidade obtida em laboratório, 83,20\%, não diferiu estatisticamente.

Das 58 ooplacas coletadas na alameda foi obtida a média de $347,8 \pm 42,1$ ovos por ooplacas e a variação foi de 46 a 676 ovos (Tabela 5). As médias das tabelas 2 e 5, quan do amostradas não diferiram estatisticamente. 
Tabela 5 - Quantidade de ovos de R. unimoda por postura coletada en $T$. avellanedae, da alameda principal da Fundação Universidade Federal de Mato Grosso, Cuiabá, MT, 1983.

Postura no

Quantidade de ovos

$\begin{array}{ll}01 & 427 \\ 02 & 407 \\ 03 & 601 \\ 04 & 502 \\ 05 & 536 \\ 06 & 541 \\ 07 & 388 \\ 08 & 220 \\ 09 & 227 \\ 10 & 284 \\ 11 & 196 \\ 12 & 476 \\ 13 & 399 \\ 14 & 515 \\ 15 & 348 \\ 16 & 357 \\ 17 & 268 \\ 18 & 046 \\ 19 & 111 \\ 20 & 549 \\ 21 & 205 \\ 22 & 156 \\ 23 & 358 \\ 24 & 354 \\ 25 & 439 \\ 26 & 676 \\ 27 & 454 \\ 28 & 661 \\ 29 & 305 \\ 30 & 305 \\ 31 & 624 \\ 32 & 088 \\ 33 & 476 \\ 34 & 302 \\ 35 & 267 \\ 36 & 210 \\ 37 & 423 \\ 38 & 289 \\ 39 & 455 \\ 40 & 426\end{array}$

(continua) 
.29 .

Tabela 5 - cont.

\begin{tabular}{cc}
\hline Postura no & Quantidade de ovos \\
& \\
\hline 41 & 112 \\
42 & 104 \\
43 & 403 \\
44 & 338 \\
45 & 124 \\
46 & 161 \\
47 & 376 \\
48 & 226 \\
49 & 205 \\
50 & 233 \\
51 & 190 \\
52 & 608 \\
53 & 291 \\
54 & 305 \\
55 & 112 \\
56 & 545 \\
57 & 331 \\
58 & 565 \\
\hline Média & 347,8 \\
\hline
\end{tabular}


Tabela 6 - Quantidade de ovos de R. unimoda e respectiva viabilidade em posturas coletadas em T. avellanedae, da alameda principal da Fundação Universidade Federal de Mato Grosso, Cuiabá, MT, 1983.

\begin{tabular}{|c|c|c|}
\hline Postura n: & $\begin{array}{c}\text { Quantidade de } \\
\text { ovos }\end{array}$ & $\begin{array}{c}\text { Viabilidade } \\
\text { (\%) }\end{array}$ \\
\hline $\begin{array}{l}01 \\
02 \\
03 \\
04 \\
05 \\
06 \\
07 \\
08 \\
09 \\
10 \\
11 \\
12 \\
13 \\
14 \\
15 \\
16 \\
17 \\
18 \\
19 \\
20 \\
21 \\
22 \\
23 \\
24 \\
25 \\
26 \\
27 \\
28\end{array}$ & $\begin{array}{r}190 \\
608 \\
291 \\
305 \\
112 \\
104 \\
403 \\
338 \\
124 \\
161 \\
376 \\
226 \\
205 \\
233 \\
205 \\
549 \\
111 \\
46 \\
268 \\
357 \\
348 \\
515 \\
399 \\
478 \\
196 \\
545 \\
331 \\
565\end{array}$ & $\begin{array}{l}92,63 \\
79,76 \\
76,28 \\
88,85 \\
99,10 \\
22,11(\mathrm{~A}) \\
97,27 \\
79,58(\mathrm{~A}) \\
57,25(\mathrm{~A}) \\
54,65(\mathrm{~A}) \\
89,62 \\
99,11 \\
0,00(\mathrm{~A}, \mathrm{~B}) \\
0,00(\mathrm{~A}, \mathrm{~B}) \\
0,00(\mathrm{~A}, \mathrm{~B}) \\
0,00(\mathrm{~B}) \\
0,00(\mathrm{~A}, \mathrm{~B}) \\
0,00(\mathrm{~A}) \\
0,00(\mathrm{~A}) \\
29,41 \\
86,49 \\
0,00(\mathrm{~A}) \\
88,22 \\
92,67 \\
0,00(\mathrm{~B}) \\
0,00(\mathrm{~A}) \\
89,72 \\
96,28\end{array}$ \\
\hline Média & 306,8 & 50,68 \\
\hline IC & $306,8 \pm 61,2$ & $50,68 \pm 16,50$ \\
\hline
\end{tabular}

(A) ovos parasitados

(B) ovos inférteis 
Tabela 7 - Quantidade de ovos de R. unimoda não parasitados e férteis, com a respectiva viabilidade en posturas coletadas em $T$. avellane dae, na alamedaiprincipal da Fundação Universidade Federal de Mato Grosso, Cuiabá, MI, 1983.

\begin{tabular}{|c|c|c|}
\hline Postura no & $\begin{array}{c}\text { Quantidade de } \\
\text { ovos }\end{array}$ & $\begin{array}{c}\text { Viabilidade } \\
\left(\frac{\circ}{0}\right)\end{array}$ \\
\hline 01 & 190 & 92,63 \\
\hline 02 & 608 & 79,76 \\
\hline 03 & 291 & 76,28 \\
\hline 04 & 305 & 88,25 \\
\hline 05 & 112 & 99,10 \\
\hline 06 & 403 & 97,27 \\
\hline 07 & 161 & 54,65 \\
\hline 08 & 376 & 89,62 \\
\hline 09 & 226 & 99,11 \\
\hline 10 & 357 & 29,41 \\
\hline 11 & 348 & 86,49 \\
\hline 12 & 399 & 88,22 \\
\hline 13 & 478 & 92,67 \\
\hline 14 & 331 & 89,72 \\
\hline 15 & 565 & 96,28 \\
\hline Média & 343,3 & 84,00 \\
\hline IC & $343,3 \pm 77,3$ & $84,00 \pm 10,40$ \\
\hline
\end{tabular}


o período médio de incubação dos ovos nas postu彑 ras foi de 5,5 dias (Tabela 8). Esse periodo variou de 5 a 7 dias, sendo que das 28 posturas observadas, 57,14\% apresentaram 5 dias de incubação, 39,29\% apresentaram 6 dias e 3,57\% apresentaram 7 dias de incubação (Figura 4).

Tabela 8 - Duração, em dias, do perỉodo de incubação dos ovos de R. unímoda, obtidos de 28 posturas, Cuiabá, MT, 1983.

Período de incubação (dias) 5 6 7 Total

$\operatorname{mp}=5,5$

$I C=5,5 \pm 0,22$
Suantidade de posturas

Total 80 66 07

\begin{tabular}{|c|c|c|}
\hline Total & 28 & 153 \\
\hline $\operatorname{mp}=5,5$ & & \\
\hline$I C=5,5 \pm 0,22$ & & \\
\hline
\end{tabular}




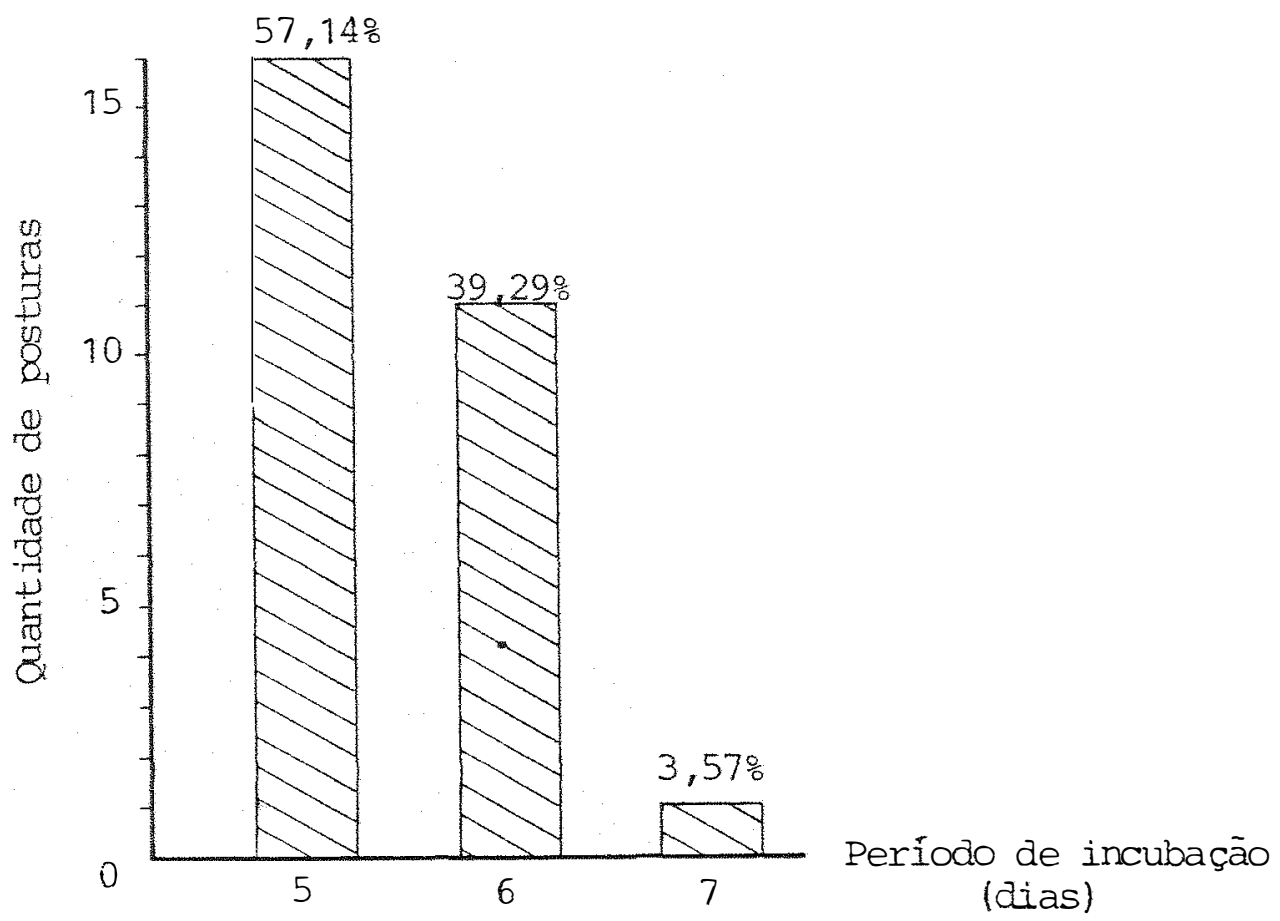

Figura 4 - Período de incubação dos ovos de R. unimoda, conforme a quantidade e porcentagem dos individuos (total de 28 posturas), Cuiabá, MT, 1983. 


\subsection{LAgARTA}

\subsection{1, ECLOSÃO}

Nas lagartas criadas em laboratório observou-se que, normalmente, o início da eclosão foi às 8:00 horas, pnolongando-se até às 18:00 horas. De uma mesma postura notou-se que a maior parte das eclosões ocorreram no mesmo dia.

\subsubsection{NÚMERO DE ÍNSTARES}

Das 40 lagartas que completaram a fase larval, $14(32,5 \%)$ apresentaram 6 instares, $25(62,5 \%)$ apresentaram 7 instares e apenas 2 (5\%) apresentaram 8 instares.

Das 14 lagartas de 6 instares, 9 originaram machos adultos e 5 fémeas adultas, representando, em relação a quantidade total de lagartas, as porcentagens de 20,9\% e 21,6\%, respectivamente. Para as lagartas de 7 instares, 14 originaram machos e 11 originaram fémeas rep̣resentando, em relação a quan tidade total de lagartas, as porcentagens de $35 \%$ e 27,5\%, respectivamente. Das 2 lagartas de 8 instares, cada indivíduo ori ginou um adulto de cada sexo, apresentando uma porcentagem de 2,5\% para cada um (Figura 5). 


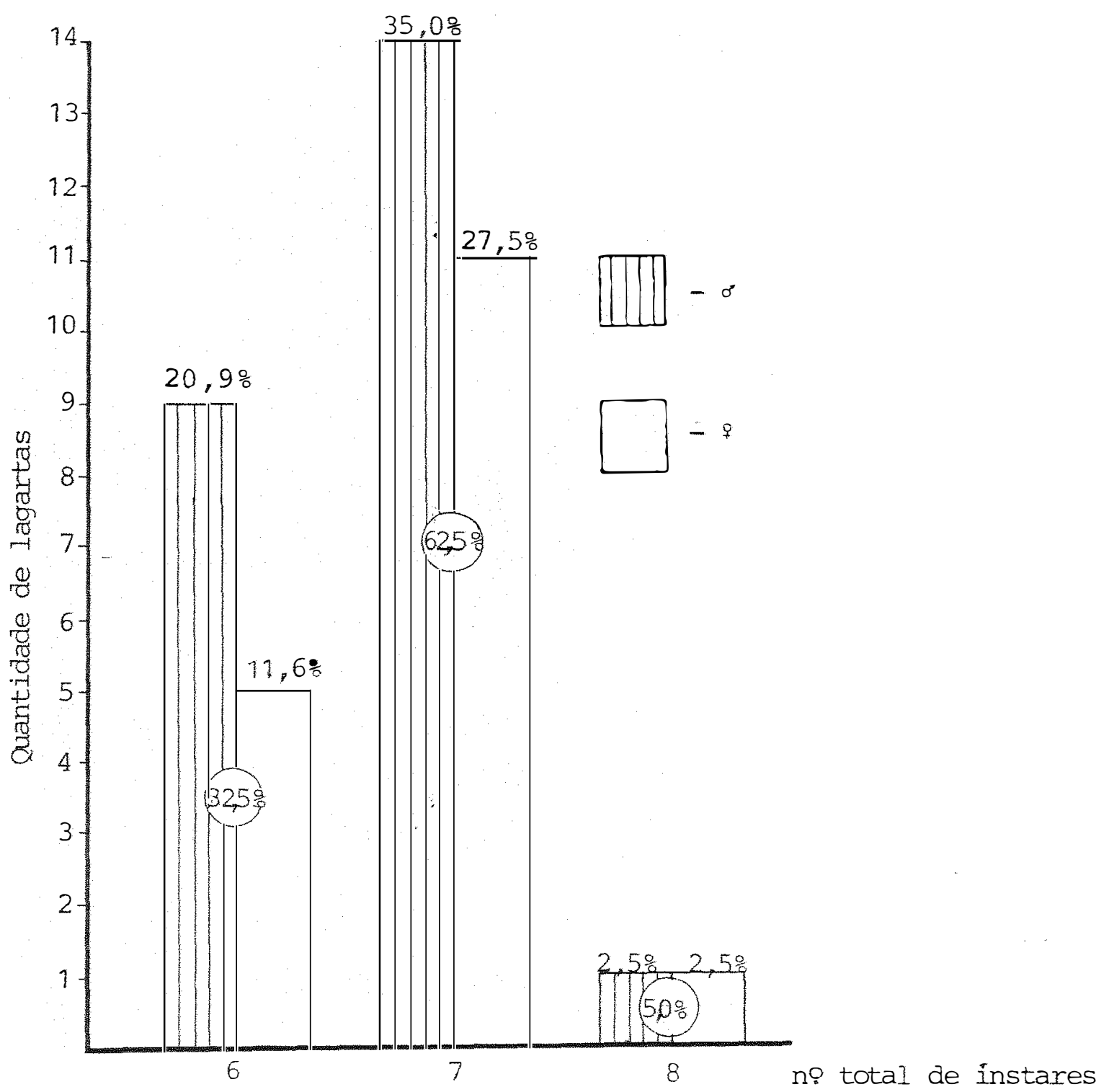

Figura 5 - Nímeros de instares do estágio larval de R. unimuda, de acordo com o sexo e a guantidade de lagartas e respectivas porcentagens (total de 40 lagartas), Cuiabá, MT, 1983. 


\section{$4,3,3$, DURACÃO DOS INSTARES}

Nas determinaçōes das durações médias de cada Instar larval foram consideradas 40 lagartas, que se desenvolveram até a fase adulta (Tabela 9, Figura 6).

Para as lagartas de seis instares, as durações médias apresentadas por feemeas e machos não diferiram estatisticamente do primeiro ao quinto instar porém, no sexto instar, as fêmeas apresentaram uma duração média maior do que a dos ma chos. A grande variação dos dados das fêmeas neste ínstar pode ter provocado uma grande amplitude do intervalo de confiança.

Para as lagartas de sete instares, as durações

médias de cada instar de machos e fêmeas não diferiram estatis ticamente, podendo as médias serem considerados como semelhantes. 


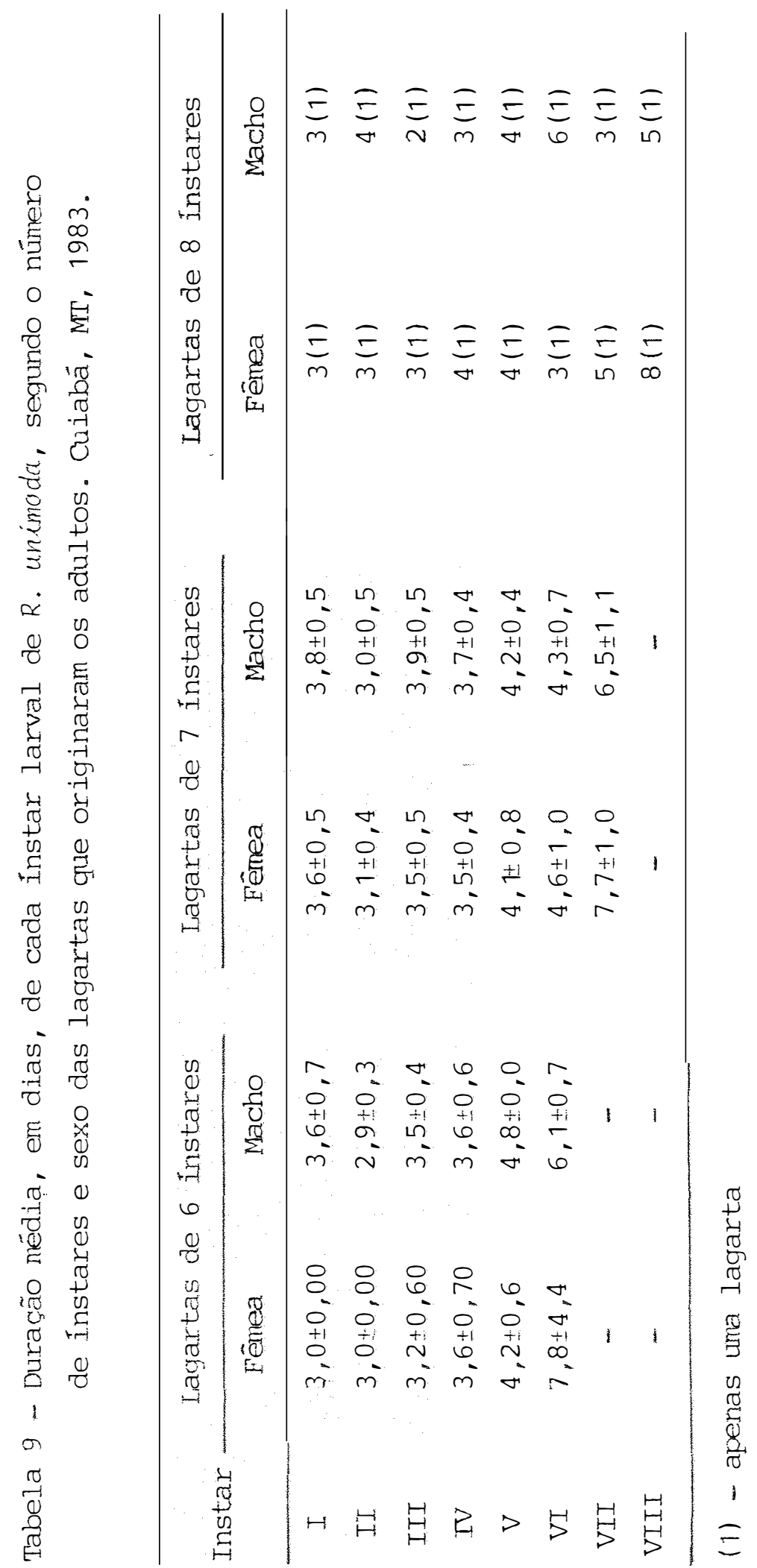


.38 .
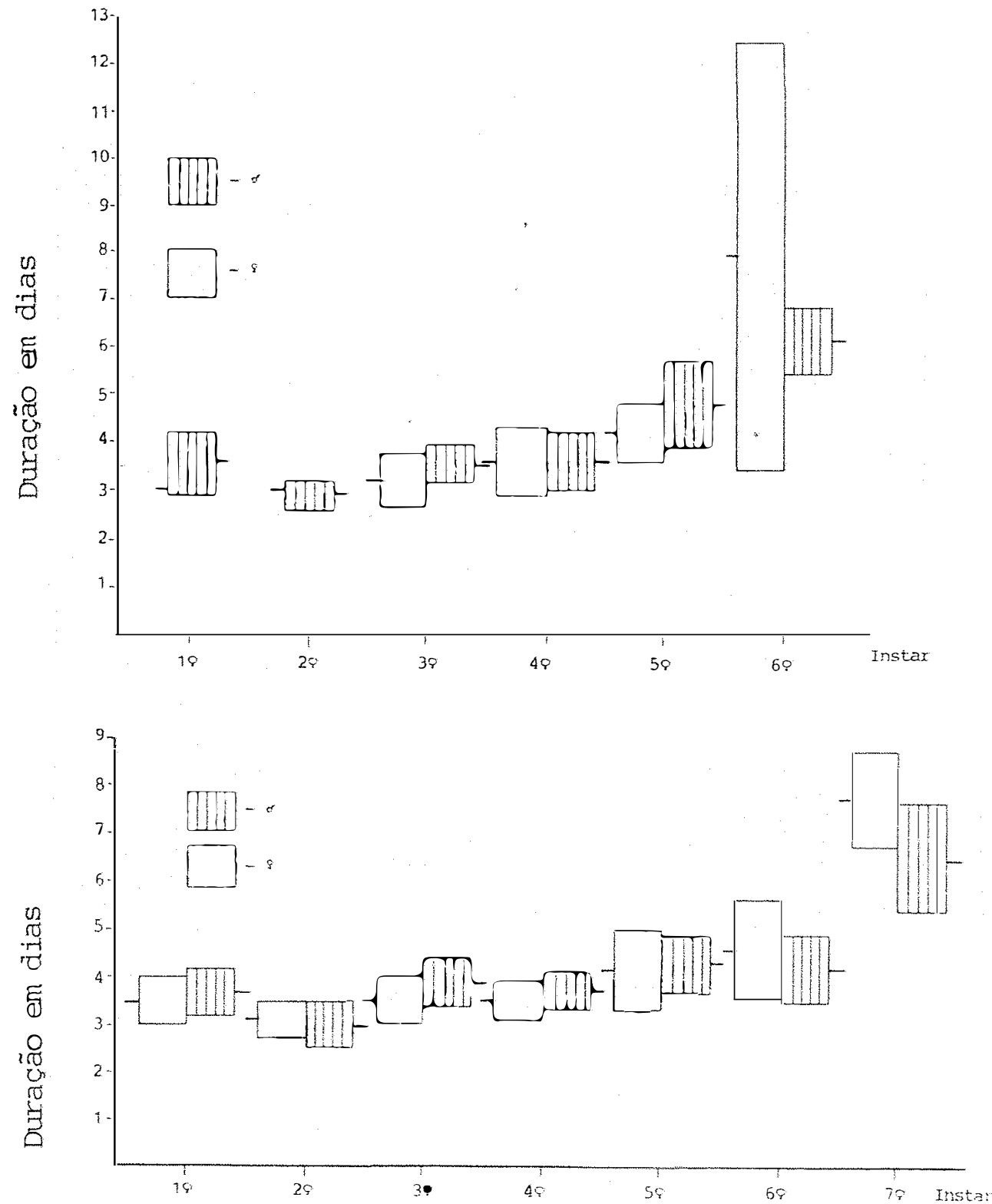

Figura 6 - Duração média e intervalo de confiança para cada instar e sexo das lagartas de R. unimoda, Cuiabá, MT, 1983. 


\subsubsection{DURACÃO DO PERÍODO LARVAL}

o período larval médio de machos e fêmeas de seis instares apresentou médias semelhantes não diferindo estatisticamente, o mesmo ocorrendo com os individuos de sete instares. Assim, pode-se calcular um período larval médio para todos os individuos com seis instares sem distinção de se xo, apresentando o valor de 24,6 dias. Da mesma forma, obteve- se uma média geral de 29,6 dias, para os indivíduos de sete instares (Tabela 10).

Tabela 10 - Duração, em dias, do período larval de R. unimoda, de acordo cam o número de instares e o sexo das lagartas que originaram os açultos, cuiabá, MT, 1983.

\begin{tabular}{ccc} 
Nümero de & \multicolumn{2}{c}{ Periodo larval (dias) } \\
\cline { 2 - 3 } instares & Fêrnea & Macho \\
\hline 6 & $24,8 \pm 5,1$ & $24,5 \pm 2,3$ \\
7 & $30,1 \pm 2,2$ & $29,2 \pm 1,8$ \\
8 & $33(1)$ & $30(1)$ \\
\hline
\end{tabular}

(1) apenas uma lagarta.

Diferiram estatisticamente os periodos larvais médios das fêmeas de seis instares com as fêmeas de sete insta res, dos machos de seis instares com os machos de sete insta- 
res e as médias gerais dos períodos larvais dos indivíduos de seis instares com os individuos de sete instares.

\subsubsection{LARGURA DA CÁPSULA CEFÁLICA}

As larguras médias das cápsulas cefálicas de la

gartas de todos os instares que originaram os adultos, encontram-se na Tabela 11.

As lagartas de seis instares, machos e fêmeas, não apresentaram médias estatisticamente diferentes até o quin to instar porém, no sexto instar, as fèmeas apresentaram uma mé dia estatisticamente maior do que o macho, ou seja, a largura média da cápsula cefálica da fêmea é maior que a dos machos neste último instar.

As lagartas de sete instares, machos e fèmeas, apresentaram médias estatisticamente diferentes, apenas no sexto e sétimo instar, sendo as médias das fêmeas maiores que as dos machos nestes instares. 


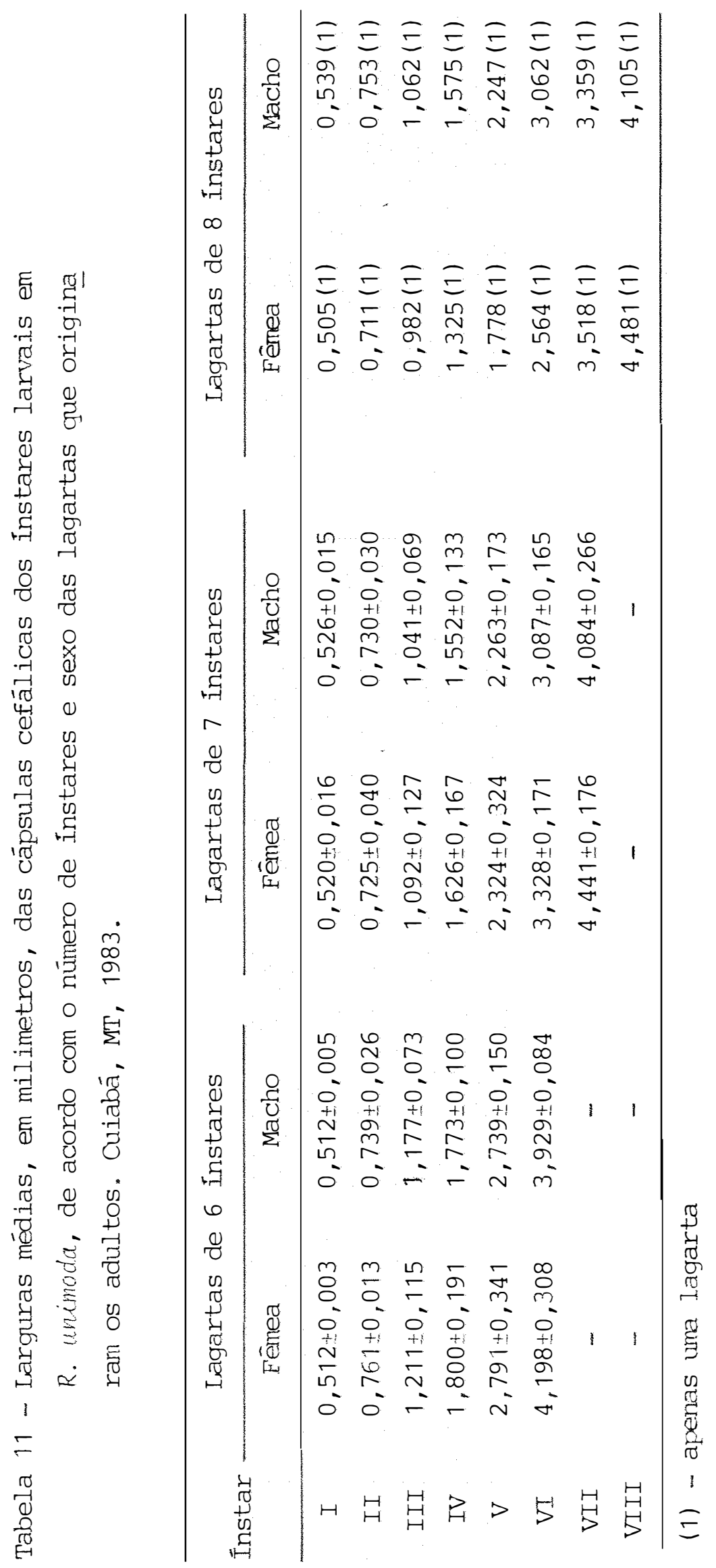

.41. 


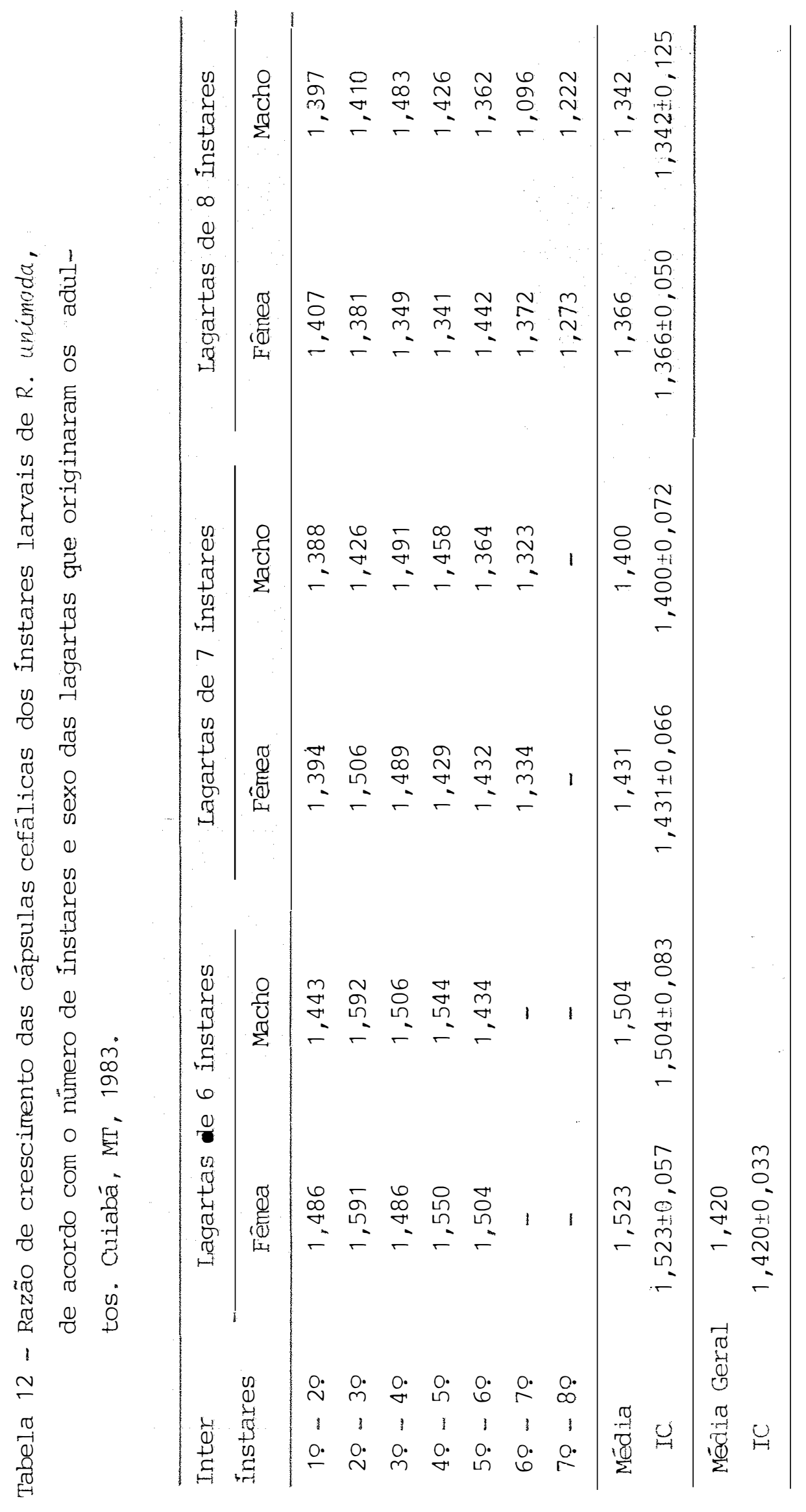

.42 . 


\subsubsection{RAZÃO DE CRESCIMENTO DA CÁPSULA CEFÁLICA}

A média geral de todos os individuos foi de

1,420. Dessa forma, pode-se demonstrar que esse parâmetro cres ceu em progressão geométrica, de acordo com a regra de DYAR (Tabela 12).

\subsection{7. ÁREA FOLIAR CONSUMIDA}

Para as determinações de consumo da ārea foliar, considerou-se toda a área raspada pelas lagartas de primeiro e segundo instares como sendo a área foliar totalmente consumida. No terceior instar alguns individuos chegaram a raspar a folha logo no início do estágio porém, posteriormente, chegaram a cor tar a folha. Sendo assim, a área foliar consumida considerada, foi a somatória da área raspada mais a cortada.

Para as lagartas de seis instares, as médias do consumo foliar por sexo não diferiram estatisticamente para o pri meiro, terceiro, quarto e quinto instares, mas no segundo e principalmente no sexto instar as médias diferiram, apresentan do as fêmeas um consumo foliar maior do que os machos (Tab.13). Os dois últimos instares, e principalmente o último, apresentaram um consumo foliar mëdio bem maior do que nos instares ante riores, sendo que no último instar o consumo foi praticamente noventa e trés e sessenta e très vezes maior do que o primeiro, 


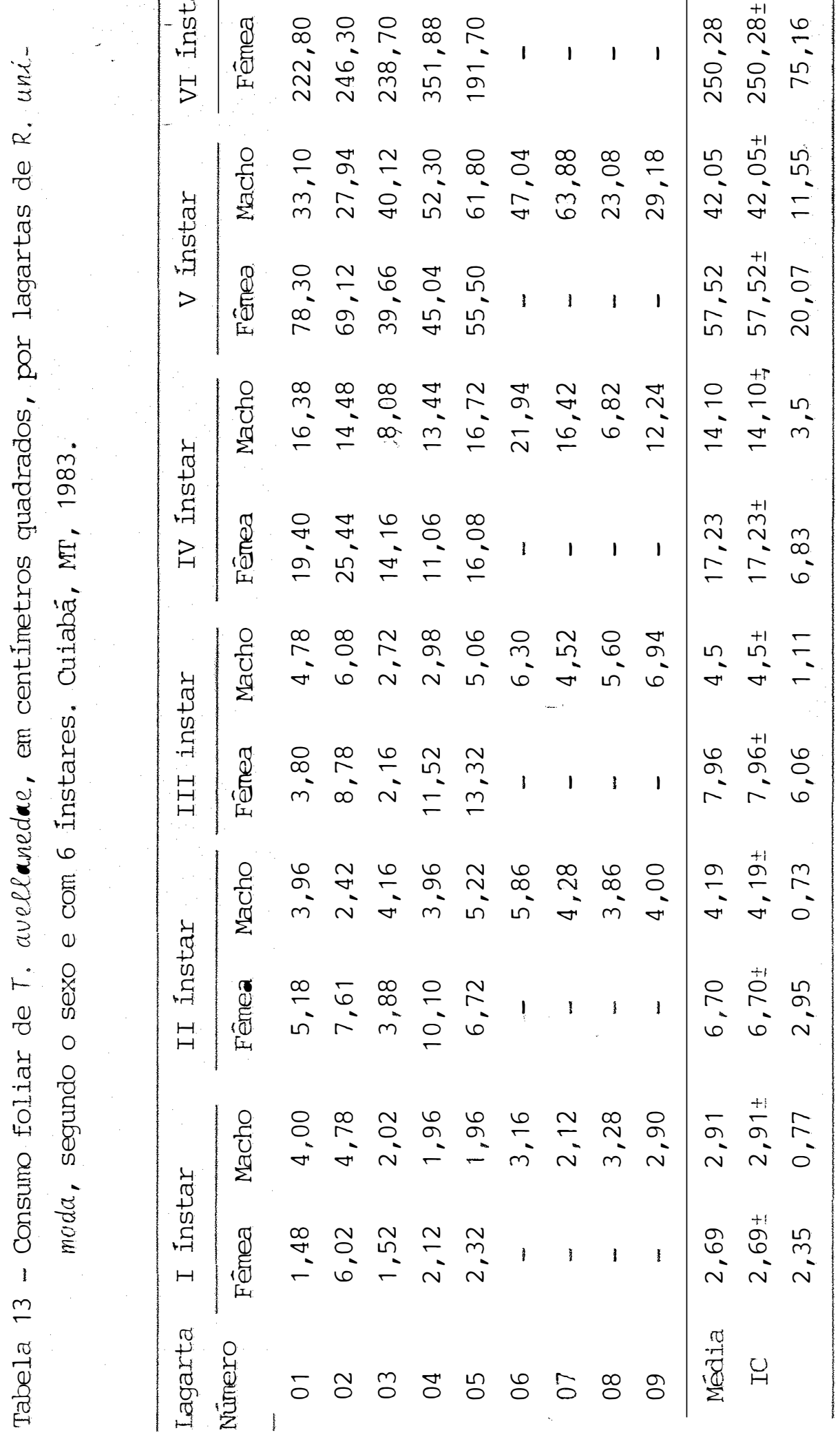


para fémeas e machos respectivamente (Fig. 7). No consumo foliar total médio os valores foram de $342,33 \mathrm{~cm}^{2}$ para as fēmeas e $250,43 \mathrm{~cm}^{2}$ para os machos, ocorrendo diferenças significativas estatisticamente, sendo que as fêmeas apresentaram um consumo maior do que os machos.

Com relação ao consumo foliar das lagartas de sete Instares (Tabela 14), levando-se em consideração os sexos e os instares (Fig. 8), as médias do consumo foliar dos machos e fēmeas não diferiram estatisticamente em todos os instares. Como se pode observar, à medida que as lagartas foram se desen volvendo, o consumo foliar médio foi aumentando, sendo mais evidenciado nos dois últimos ínstares e principalmente no últi mo, onde a proporção foi quase quatro vezes superior ao penúltimo instar, para ambos os sexos, e de noventa e cinco e cincoenta e três vezes maior do que o primeiro instar para fēmeas e machos, respectivamente. O consumo total médio foi de $281,60 \mathrm{~cm}^{2}$ para as feemeas e $261,42 \mathrm{~cm}^{2}$ para os machos, cujos valores não diferiram estatisticamente.

A média do consumo foliar do estägio larval, de todos os individuos medidos, foi de $275,34 \mathrm{~cm}^{2}$, não se levando em consideração as lagartas de oito instares.

Para as duas lagartas de oito instares o consumo foliar por instar foi de 2,$64 ; 5,48 ; 1,76 ; 8,44 ; \quad 29,82$; 62,$62 ; 25,92$ e $105,52 \mathrm{~cm}^{2}$ para o primeiro, segundo, terceiro, quarto, quinto, sexto, sétimo e oitavo instares, respectivamen te e com um total de $242,2 \mathrm{~cm}^{2}$ somente para o individuo que o- 


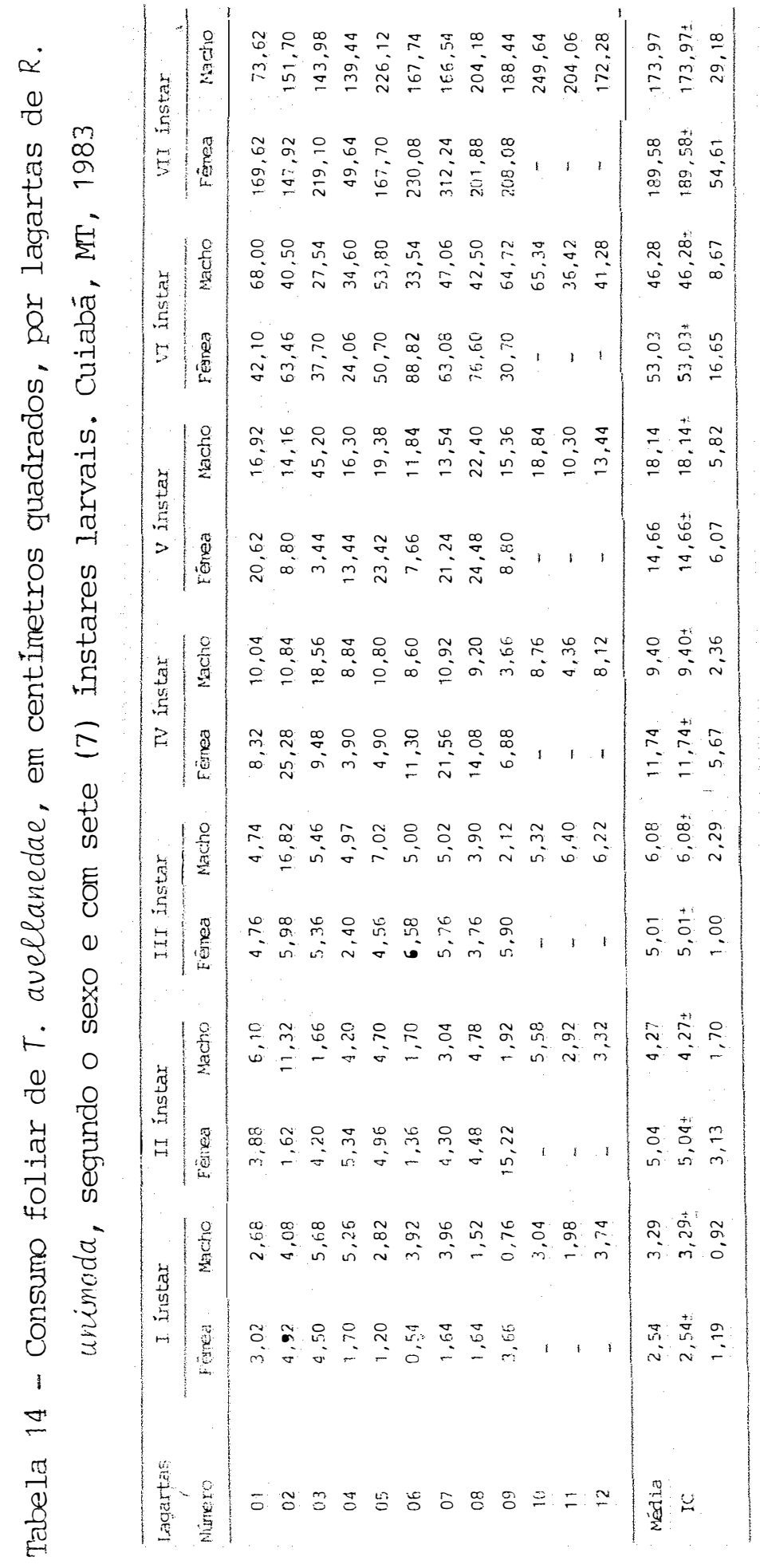


.47 .

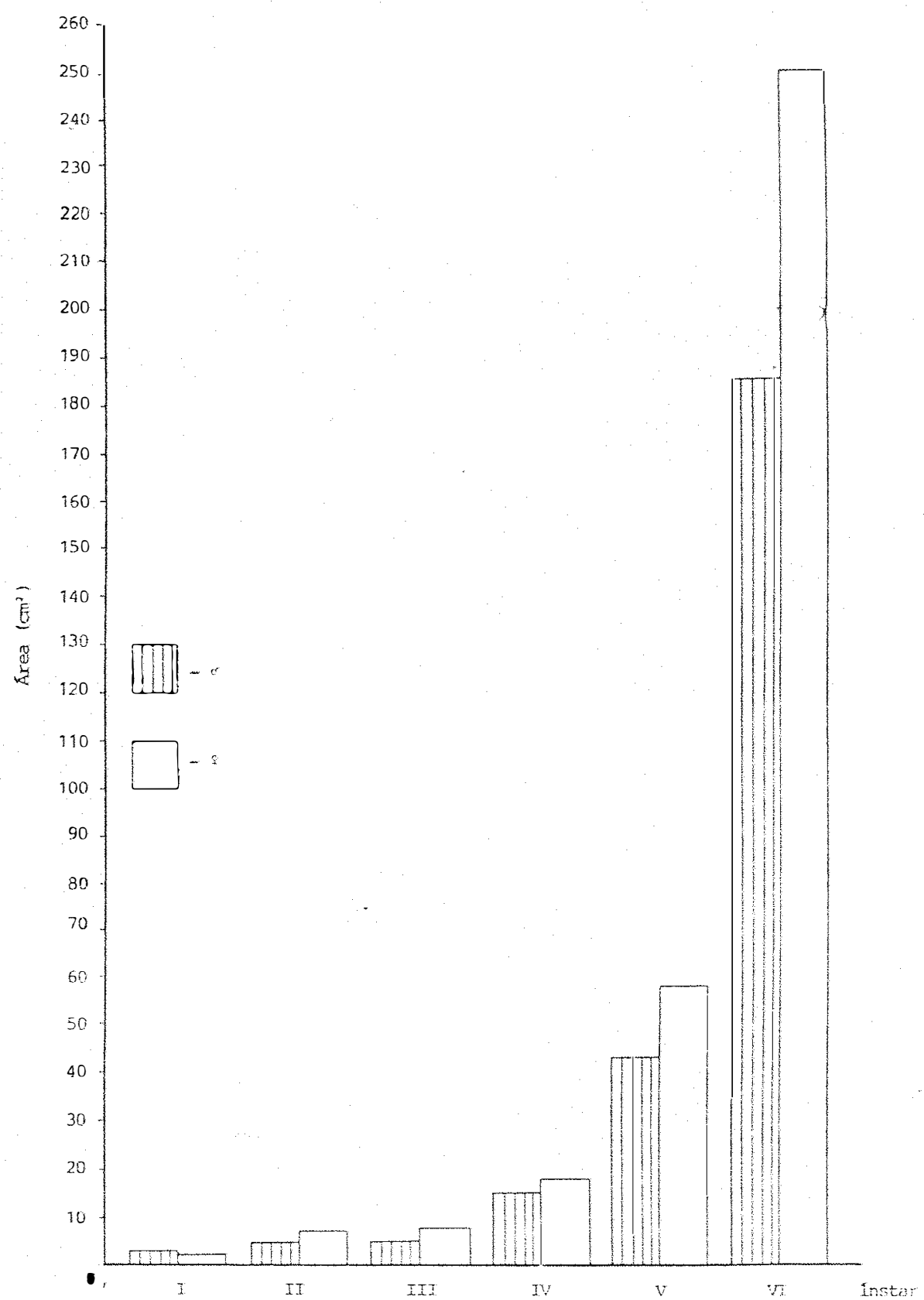

Figura 7 - Consumo/Instar, de acordo com o sexo, das lagartas com periodo larval de seis instares, en R. unimoda, Cuiabá, MT, 1983. 
.48.

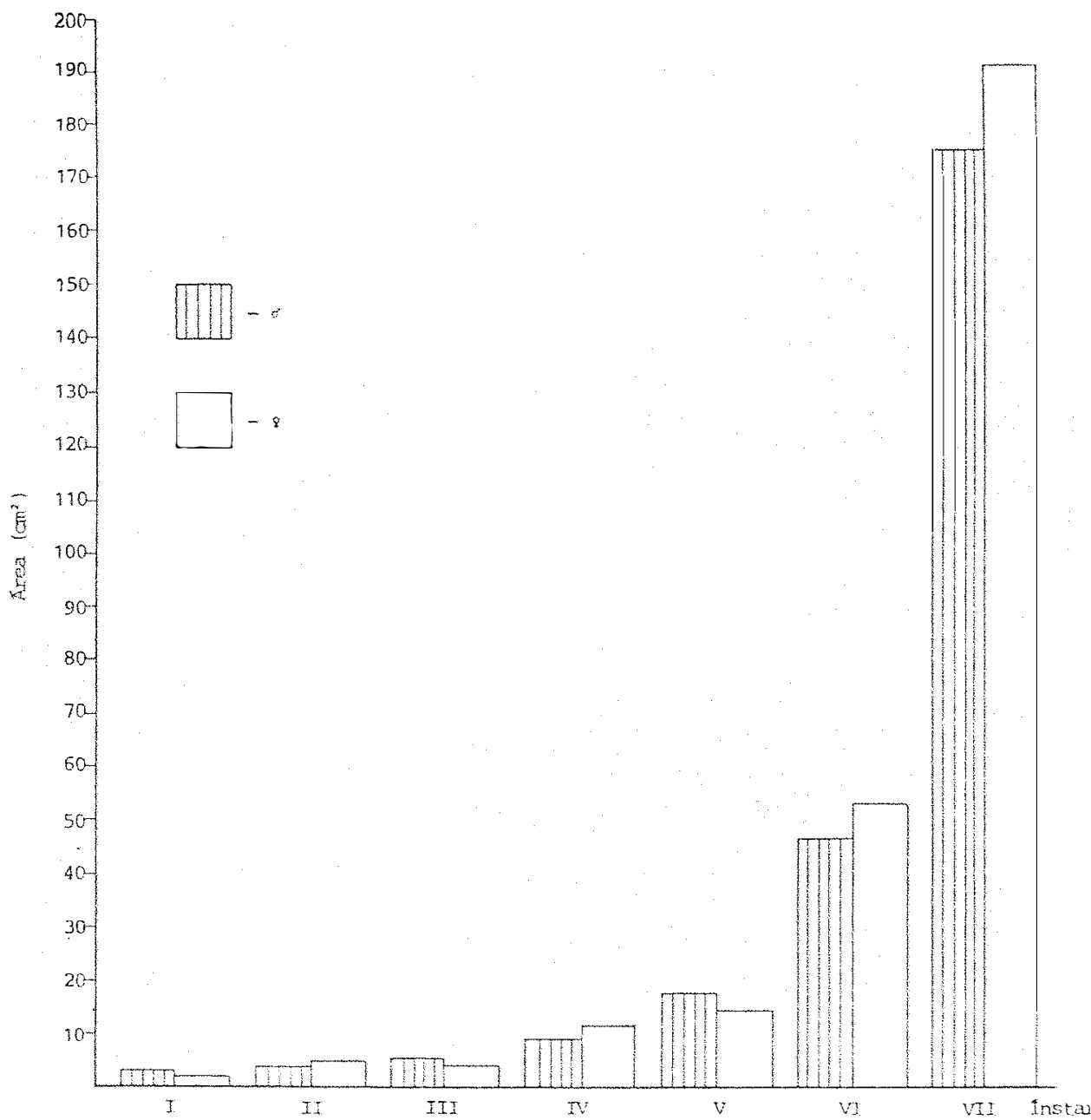

Figura 8 - Consumo/instar, de acordo com o sexo, das lagartas corn período larval de sete instares, en R. unimoda, Cuiabá, MT, 1983. 
riginou o macho adulto. Para o único individuo que originou a fêmea adulta, o consumo foliar por instar foi de 2,10; 5,14; 3,$28 ; 7,86 ; 24,14 ; 48,44 ; 300,42$ e $206,88 \mathrm{~cm}^{2}$ para o primeiro até o oitavo instar em sequência, o consumo total foi de $598,24 \mathrm{~cm}^{2}$.

\subsubsection{SOBREVIVÊNCIA AO JEJUM}

Em todas as testemunhas não houve nenhuma morte durante todo o período de observação.

Para as lagartas do primeiro instar, nas primei ras doze horas o Indice de mortalidade foi muito pequeno, pois apenas 4 indivíduos morreram. No entanto, no período compreendido entre às 12:00 e 24:00 horas a mortalidade foi bem acentuada, restando apenas 18 individuos. No terceiro periodo de observação (24:00 - 36:00 horas), a mortalidade atingiu 100\%. Pelos resultados obtidos ficou demonstrado que as lagartas apresentaram uma boa capacidade de sobrevivência, nas primeiras doze horas, o mesmo não ocorrendo nos períodos posteriores lFi gura 9).

No segundo instar, observou-se que no primeiro período não houve mortalidade e, embora tenha ocorrido no segundo período, a quantidade de lagartas mortas no final das 24 horas foi de apenas 12 individuos. No terceiro período de observação notou-se que a mortalidade foi bastante elevada uma 


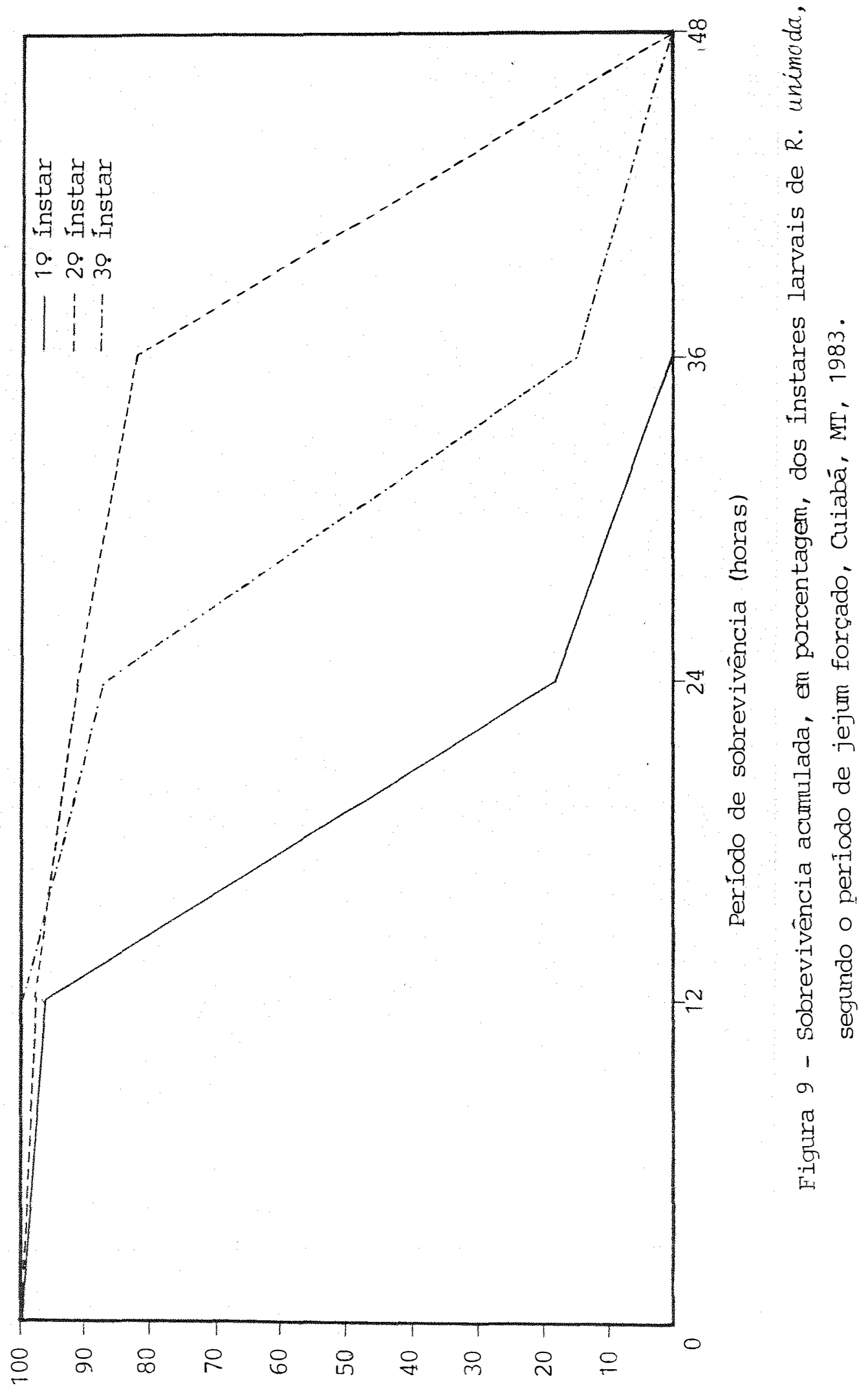

(\%) seqtebet әp әрертұtueno 
vez que, no final de 36 horas, restaram apenas 15 individuos que morreram no período seguinte, no final de 48 horas.

No terceiro instar observou-se que a mortalida

de foi pequena no primeiro periodo, com apenas 2 individuos mor tos no final das 24 horas. No terceiro periodo a mortalidade foi maior do que no período anterior, embora bem menor do que no quartó e último período pois, no final das 36 horas, o núme ro de individuos mortos foi de 19, ao passo que no último período a mortalidade foi de $100 \%$

Observando-se todos os instares, notou-se que a alimentação é extremamente importante para as lagartas, pois os períodos de sobrevivēncia ao jejum não são tão Iongos. Notou- se tambēm que as quedas bruscas na sobrevivência sempre ocorreram com uma diferença de um período 112:00 horas) de um. Instar para o outro, ou seja, para as lagartas de primeiro instar ocorreu no segundo periodo, para as lagartas de segundo Instar ocorreu no terceiro periodo e para as lagartas de terceiro instar ocorreu no quarto período.

De todas as lagartas observadas, as que apresentaram maior sobrevivēncia ao jejum foram as de segundo e terceiro instar, devido a alimentação que receberam no instar anterior ou Instares anteriores. Dessa forma, a possibilidade de sobrevivência dessas lagartas, quando na busca de novas fontes de alimentos torna-se maior. 


\subsubsection{VIABILIDADE}

Das 100 lagartas no início morreram 52, portanto, a viabilidade foi de.48\%. Considerou-se apenas 40 lagartas para as medições pois, em 8 lagartas não foi possível a determinação do sexo, uma vez que esses individuos morreram antes da fase adulta. Dessas 52 lagartas, 39 morreram por ... ataque de fungo, apesar das medidas profiláticas adotadas, e 13 morreram por fatores não determinados. Os sintomas de ataque dos fungos foram semelhantes aos do campo. A manipulação diāria das lagartas foi um outro fator que deve ter contribuido para o aumento da mortalidade, nas condições de laboratório.

Considerando-se os instares, isoladamente, as lagartas apresentaram sobrevivências de 93,0; 89,2; 90,4; 97,3; 95,$9 ; 91,4 ; 100,0$ e 100\% nos primeiro, segundo, terceiro, quar to, quinto, sexto, sétimo e oitavo instares, respectivamente, sendo que os instares que apresentaram os menores indices de sobrevivência foram o segundo e o terceiro, com 9 indivíduos provavelmente mortos por fungo e um de causa desconhecida, para o segundo instar e 8 indivíduos mortos também por fungo, no terceiro instar. Os instares que apresentaram os maiores indices de sobrevivência foram o quarto, o sétimo e o oitavo.

Como se pode observar a causa maior da mortalidade foi o fungo. 


\subsubsection{CARACTERIZACÃO DOS INSTARES}

\section{- I instar:}

Coloração geral do corpo amarelo-clara sendo a cabeça de coloração amarela mais escura. Cabeça com os sulcos frontais e epicranial bem finos e hialinos; 6 ocelos negros $\underline{10}$ go acima das antenas; mandíbulas de cor marrom e semitransparentes. Tórax com o 19 segmento mais desenvolvido do que 02 ? e este mais do que 03 , tendo este último segmento o mesmo ta manho do 19 segmento abdominal. As pernas são amareladas com a garra apical de coloração marrom e pouco pilosas. Espiráculos di minutos de coloração ligeiramente esbranquiçada confundindocom a coloração do tegumento. Pêlos, como na cabeça, rảios, finos, hialinos e pontiagudos. O primeiro segmento torácico ligéiramente mais piloso do que os demais e apresentando também um nū mero maior de verrugas. O segundo e o terceiro segmentos apresentam, cada qual, na região costal um par de verrugas dispostas lado a lado, no sentido transversal ao eixo longitudinal do corpo sendo que cada verruga comporta duas cerdas. Abdome rala mente coberto por pélos semelhantes aos descritos anteriormente. Na região costal, aparecem duas verrugas próximas, dispostas transversalmente ao eixo longitudinal do corpo, localizadas na parte anterior de cada segmento e cada uma com uma cerda curta; a seguir, no mesmo segmento, surgem duas verrugas, dis tanciadas entre si também dispostas transversalmente e com uma cerda longa em cada uma delas. No oitavo segmento o par de ver 
rugas da parte anterior do segmento, desaparece dando lugar a uma única verruga de posição central e mais desenvolvida do que as demais de todo o corpo, partindo do seu ápice duas cerdas. Os colchetes são de coloração marrom (Fig. 10) .

\section{- II instar:}

Coloração do tórax e abdome amarelo clara, cabe ça de coloração alaranjada, pêlos mais escuros do que no instar anterior tendendo para o marrom claro. As verrugas do tórax e do abdome, excetuando-se a do oitavo segmento dorsal, apresentam-se com uma coloração verde-limão de tonalidade clara. Os pêlos que recobrem essas verrugas são da mesma coloração e tonalidade dos encontrados na cabeça. Na região dorsal do segundo anel torácico, aparece uma mancha marrom escura entre as duas primeiras verrugas transversais e duas manchas da mesma cor, porém mais tênues e dispostas antero-lateralmente a estas ver rugas. Na região dorsal do terceiro anel torácico surgem manchas nas mesmas disposiçöes, mas as duas manchas antero-laterais ao primeiro par de verrugas são mais nitidas. Na região lateral encontram-se duas verrugas dispostas verticalmente, em cada segmento, de coloração verde-limão. Os pêlos presentes nas pernas torácicas e na região ventral são hialinos. Na região dorsal do abdome as duas primeiras verrugas de cada segmento, a 
presentam-se com duas manchas marrom escuras, dispostas antero -lateralmente, semelhantes às encontradas no tórax, porém com a mancha central ausente. A grande verruga dorsal do oitavo segmento assume forma e coloração distinta da encontrada no primeiro instar, apresentando-se de forma cónica e circundada por pequenas cerdas eretas, com coloração idêntica as demais encontradas sobre o dorso; duas cerdas longas e hialinas, dispostas lateralmente, partem do ápice desta verruga; toda a região dorsal e a base dessa verruga de coloração alaranjada e a parte apical (terço superior) amarelada. os segmentos posterio res ao oitavo segmento não têm manchas negras e apresentam duas verrugas na mesma disposição e coloração das encontradas nos segmentos anteriores. A parte ventral, incluindo as pernas, é totalmente amarelada com cerdas hialinas, distribuidas esparsa mente; os colchetes têm a mesma coloração do primeiro ínstar (Fi gura 11). 
.56.

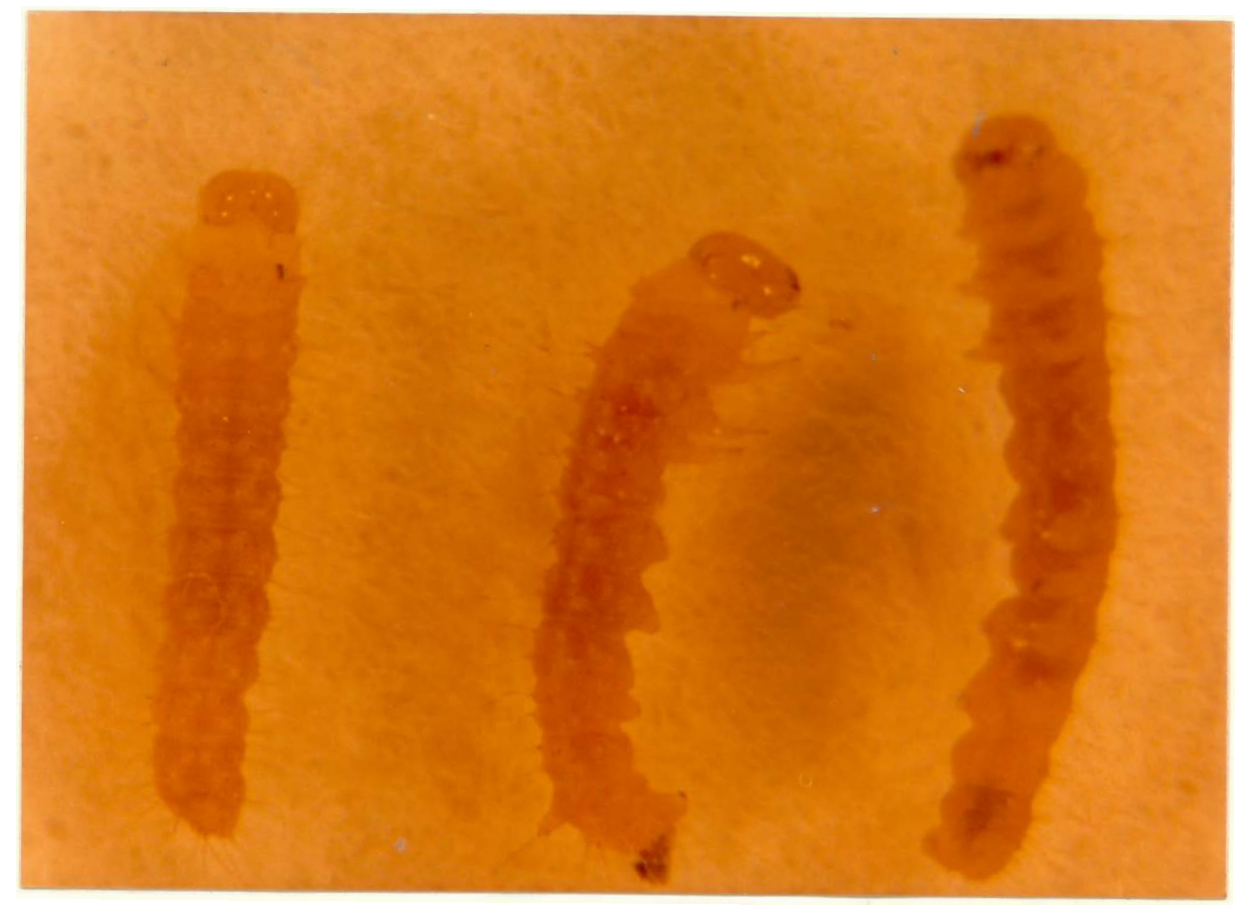

Figura 10 - Lagartas de R. unimoda no primeiro Instar. (Aumento 25X)

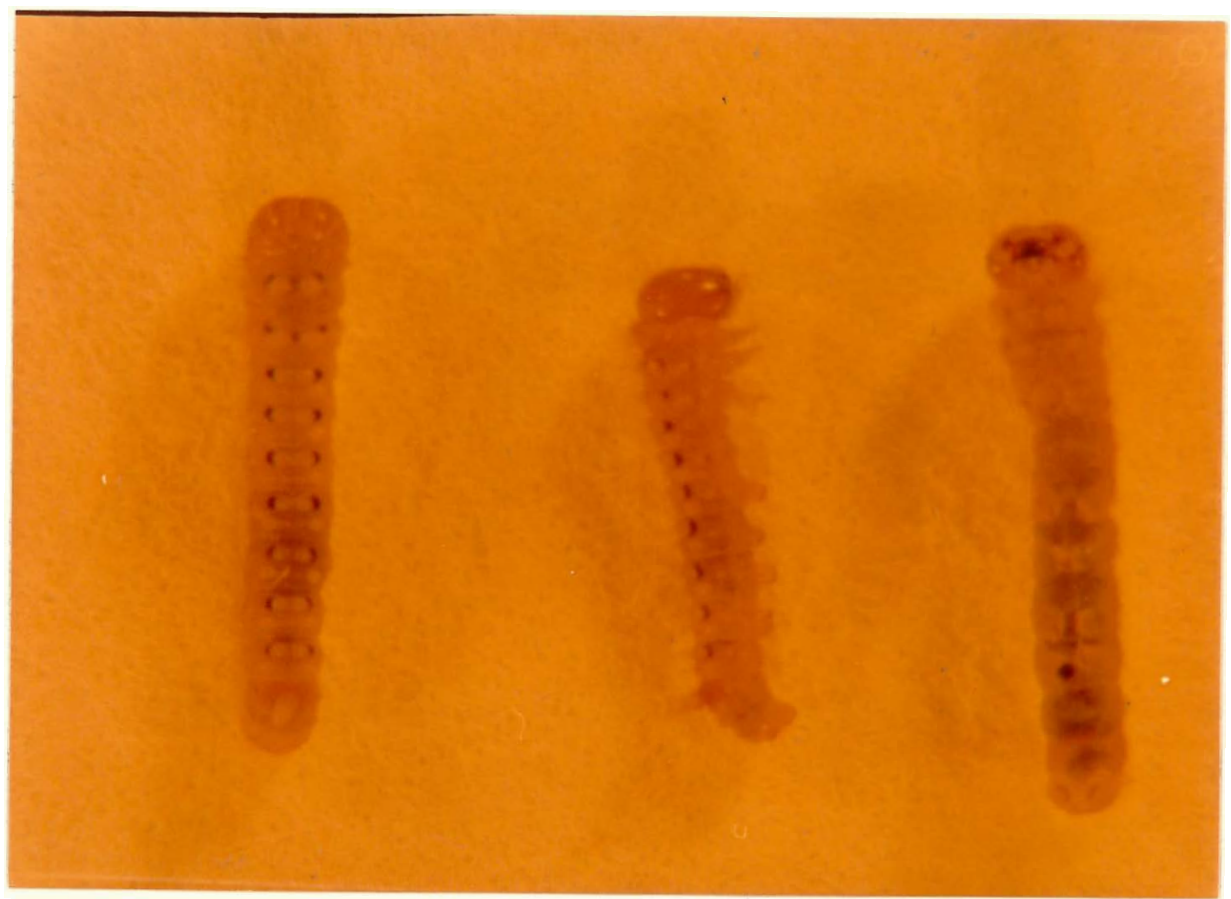

Figura 11 - Lagartas de R. unimuda no segundo instar. (Aumento 12X) 


\section{- III instar:}

Cabeça semelhante ao instar anterior, apenascom a coloração alaranjada um pouco mais intensa. Tórax e abdome com coloração geral amarela, porëm mais escura do que nos dois primeiros instares e tambérn verrugas de coloração verde- limão mais escuras; coloração das cerdas idênticas ao instar anterior, diferindo apenas no tamanho que é menor dos encontrados na região dorsal do abdome; cerdas das verrugas mais longas do que as encontradas no instar anterior. O primeiro segmento torácico com coloração alaranjada em sua região dorsal. Manchas do segundo e terceiro segmentos costais negras. Entre as duas verrugas laterais de cada segmento uma mancha negra. A parte ventral e as pernas mais escuras do que no instar anterior. Na região costal do abdome as manchas antero-laterais das verrugas anteriores tornam-se negras e no espaço intercalar a essas verrugas surge uma mancha negra; nas verrugas posteriores de cada anel costal surgem duas manchas negras, de tamanho reduzi do, circundando-as internamente. A grande verruga do oitavo seg mento apresenta na sua base $(1 / 3)$ e em toda região costal, uma coloração alaranjada, sendo que o restante (2/3) dessa verruga é de coloração negra. Os segmentos posteriores apresentam - se somente com uma coloração mais escura do que no ínstar anterior. Os espiráculos apresentam uma pinta negra circundando-os na porção superior. Região ventral mais escura do que nos instares anteriores (Figura 12). 
.58 .

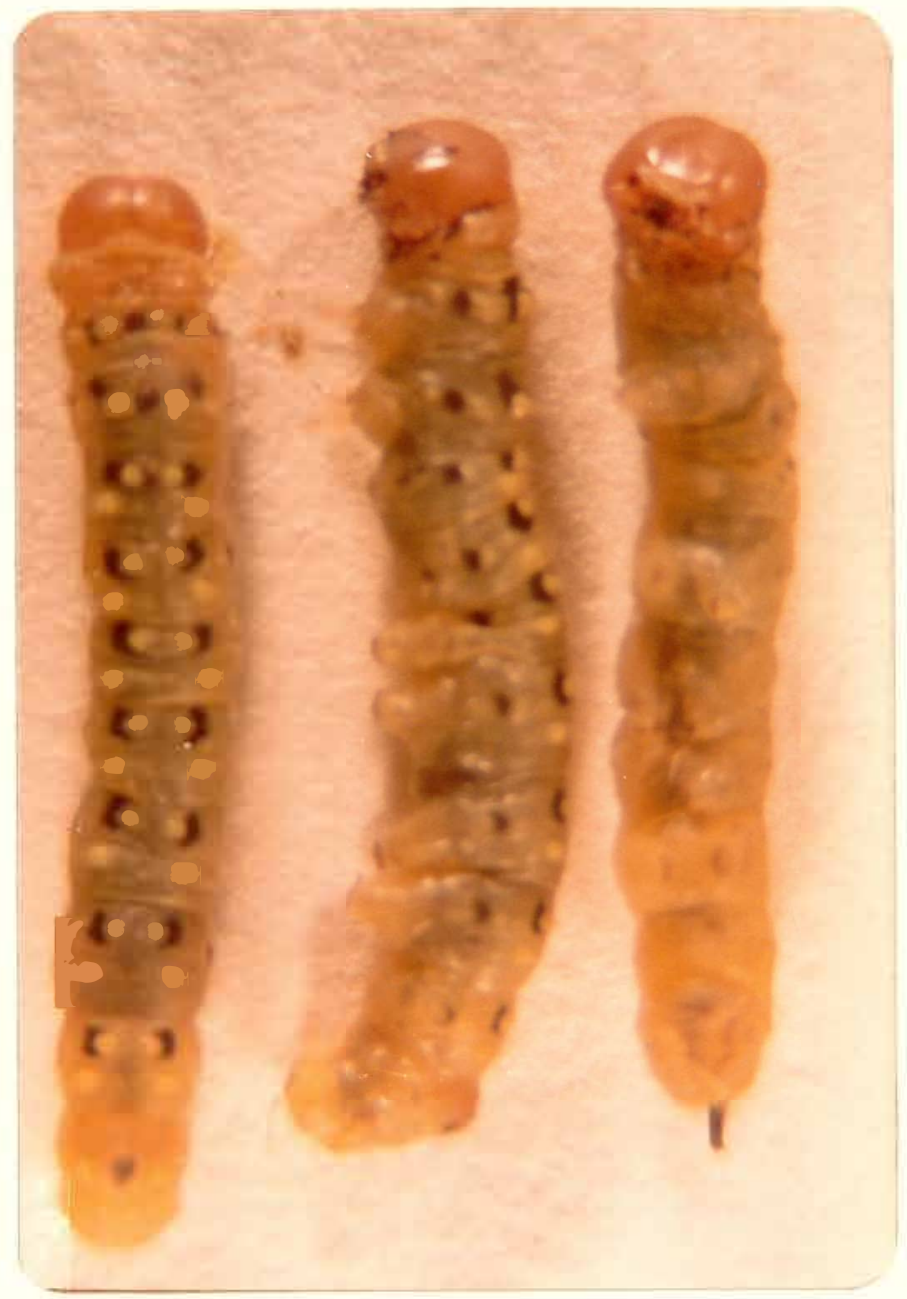

Figura 12 - Lagartas de R. unimoda no terceiro instar. (Aumento 12X) 


\section{- IV instar}

- Cabeça, tórax e abdome sem coloração igual ao instar anterior. Espiráculos toräcicos e abdominais mais evidenciados do que no instar anterior, com a abertura 'sexterna branca e peritrema marrom escuro. Sob microscópio estereoscó pico notou-se uma fina listra lateral de coloração menos intensa do que o tegumento. A listra é uma traquéia lateral, que es té em contato com os espiráculos percorrendo o corpo no sentido longitudinal, indo do primeiro espiráculo torácico até o pe núltimo do abdome e só é visto pelo fato do tegumento ser ligeiramente hialino. Manchas negras próximas às verrugas anteriores de cada anel abdominal do tergo tornam-se mais nitidas e as manchas intercalares desaparecem. Nas verrugas localizadas na parte posterior de cada anel abdominal, não mais se encontram as manchas negras próximas a estas. No nono segmento uma mancha negra de tonalidade fraca ladeia, externamente, cada uma das duas verrugas.

\section{- $V$ instar}

Cabeça alaranjada com o clípeo de coloração verde-limão. O tórax e o abdome com uma coloração verde-limão cla ra com tons amarelados, corpo totalmente recoberto por pêlos extremamente diminutos. As demais caracteristicas encontradas

no instar anterior permanecem inalteradas tanto o tórax como o abdome, excetuando-se a listra lateral (traquéia interna) que 
tem a mesma coloração do corpo, porém bem mais clara e as pernas abdominais e anais que apresentam os colchetes bem evidenciados, percebendo-se os ganchos em disposições biordinais em mesossérie e situados na parte interna de cada perna. Alguns indivíduos apresentam uma tendência para um maior escurecimento do corpo, que no instar seguinte dão os individuos do tipo negro.

\section{. VI instar}

As lagartas deste instar diferenciam-se dos individuos do instar anterior peḷa coloração amarelo alaranjada encontrada no último segmento dorsal do abdome e nas pernas anais. Neste instar surgem lagartas com tipo negro, cuja cabeça não difere do padrão comum. As regiões de coloração amarelo-alaranjada não sofrem mudanças na cor. Todo o tórax e o abdome, tanto na região dorsal como lateral, apresentam-se negros com manchas verde-limão claras, dispostas irregularmente e com dimensões variáveis; verrugas dorsais e laterais com a mesma coloração das manchas que recobrem o corpo. Abertura dos espiráculos de cor branca com o peritrema em negro, bastante intenso. Vaso dorsal com uma tonalidade mais clara do que o resto co corpo. 


\section{- VII instar}

Coloração geral do corpo mais opaca: A característica marcante neste instar é o atrofiamento da grande verru ga do oitavo segmento dorsal do abdome. O atrofiamento é carac terizado inicialmente por um murchamento, a partir do ápice, vindo a verruga a dobrar-se posteriormente e, de tal forma, que torna-se difícil evidenciá-la. Apenas em alguns indivíduos não foi notado o atrofiamento (Figura 13).

\section{. VIII instar}

As lagartas do oitavo instar diferenciam-se das lagartas do sétimo instar apenas pelas dimensões maiores do corpo (Figura 14).

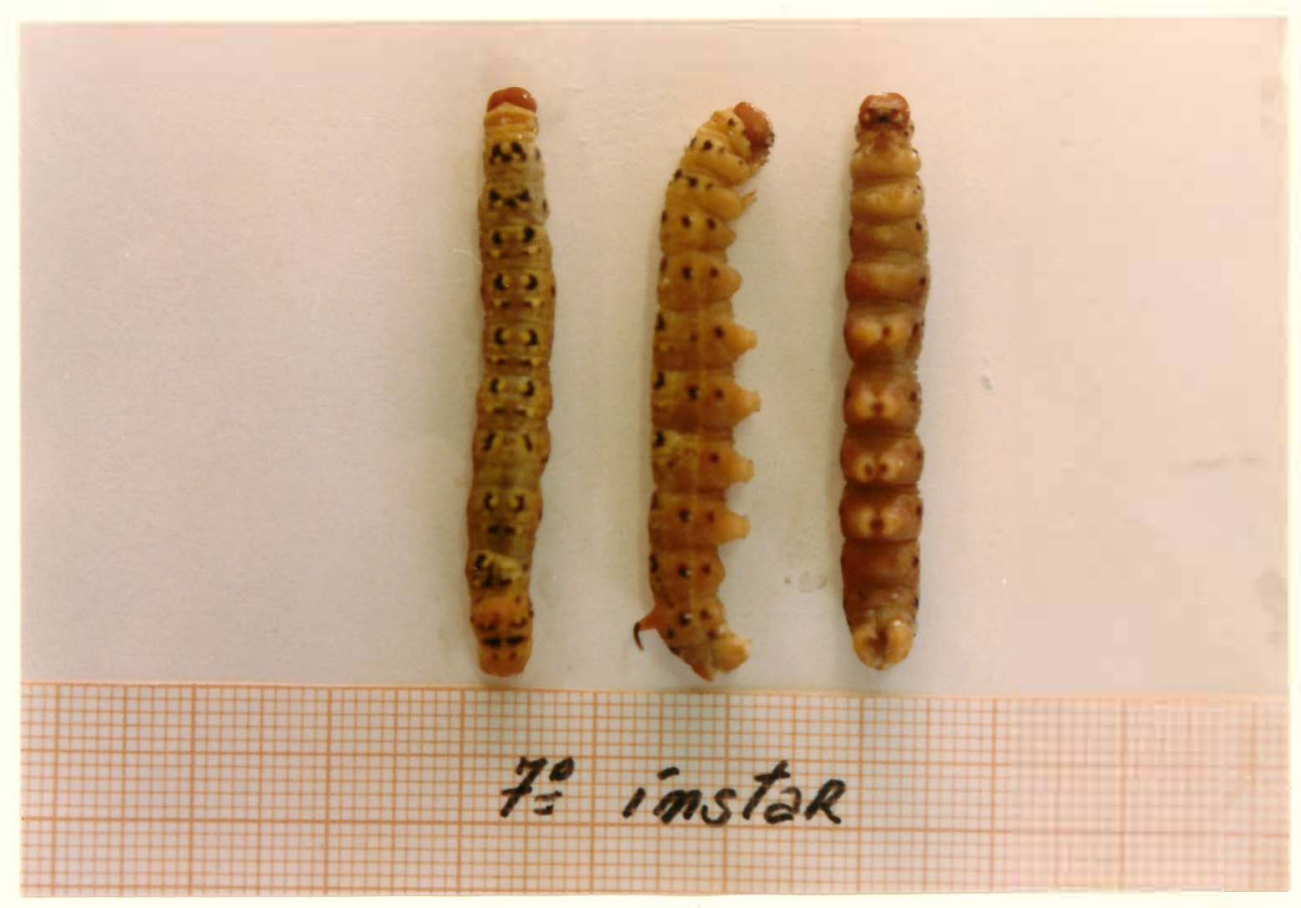

Figura 13 - Lagartas de R. unimoda no sétimo instar. 


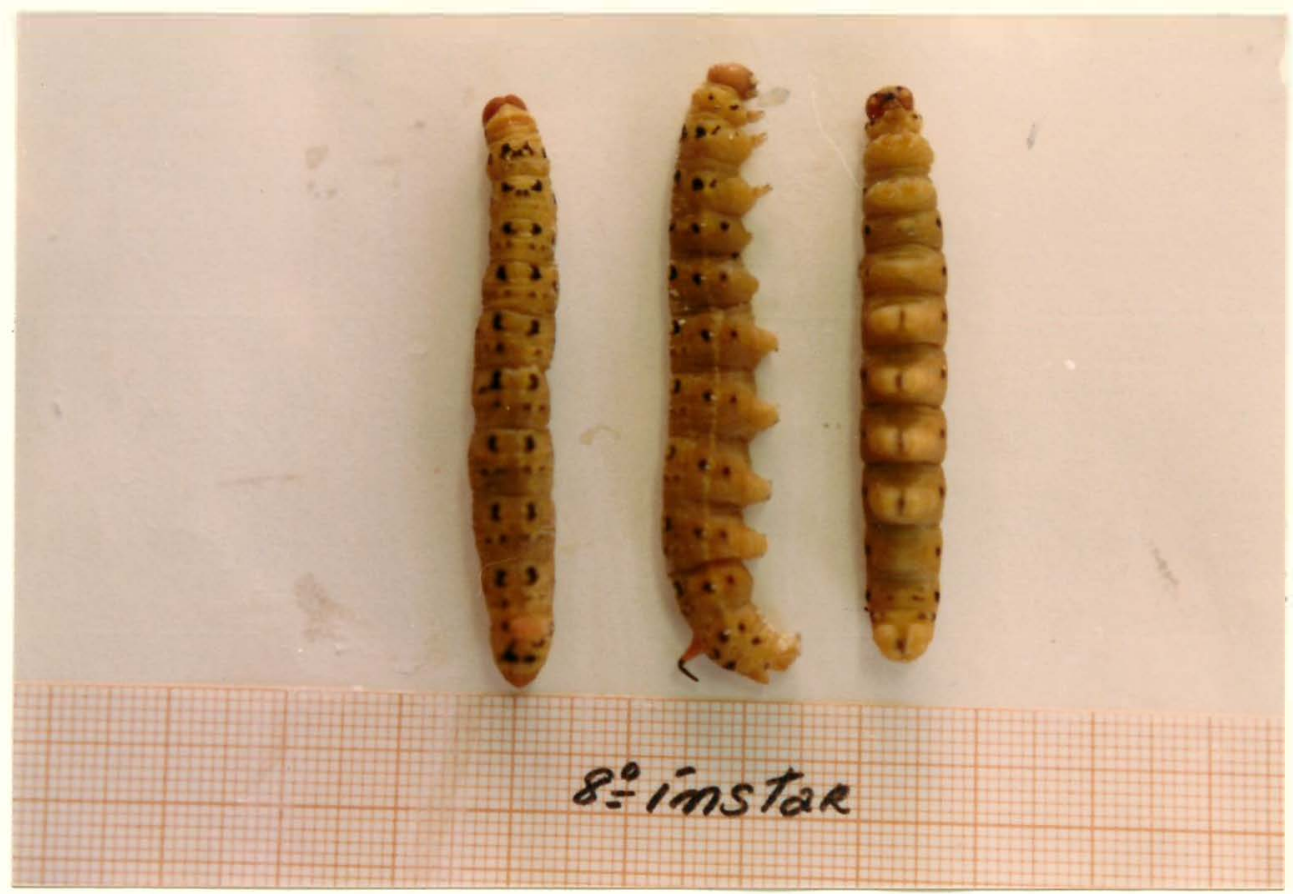

Figura 14 - Lagartas de R. unimoda no oitavo ínstar.

\subsubsection{COMPORTAMENTO}

Em todas as massas de ovos observadas notou-se que, durante o processo de eclosão, as lagartas comem a parte superior do córion, construindo um orifício suficiente para a passagem do corpo. Em laboratório, logo após a eclosão, as lagartas tornam-se bastante agitadas, procurando imediatamente a fonte de alimento. Algumas lagartas iniciam sua alimentação na página superior da folha, sendo que a maioria inicia pela pági na inferior. Observa-se também que, quando a página inferior é quase totalmente danificada, as lagartas passam para a página superior. Nos primeiros instares as lagartas apresentam foto- 
tropismo negativo e à medida que os instares se sucedem esta reação diminui e no último instar aparentemente nao apresentam qualquer reação à luz.

As lagartas de $R$. unimoda, apresentam hábitos gregários em laboratório e também no campo, mas a partir do ter ceiro instar inicia-se a dispersão.

No primeiro instar, as lagartas raspam a superfície foliar e a região preferida é ao longo da nervura princi pal, mas alguns individuos comem os bordos das folhas em peque nas quantidades. A raspagem da superfície foliar continua até o terceiro instar, sendo que neste instar também se observa o hábito de comer o bordo foliar. Nos instares sucessivos a ali mentação é feita iniciando-se pelos bordos foliares. Nos trēs últimos instares a voracidade é tamanha, que as lagartas chegam a comer as nervuras secundárias e a principal. Observa-se também que, quando a alimentação se dá através do corte, o processo tem inicio pelos bordos dirigindo-se para a parte central da folha. A alimentação ocorre durante o dia e à noite em todos os instares, sendo que a atividade alimentar diurna é mais intensa que a noturna.

$\bar{A}$ medida que os instares se sucedem as lagartas diminuem a movimentação de forma progressiva, sendo que nos trēs últimos ínstares as movimentações ocorrem apenas para a alimentaçāo. Na maioria das lagartas observadas constatou - se 
que quando a ecdise estava para ocorrer, estas procuravam as bordas das placas de Petri. Imediatamente após a mudança de Instar, as lagartas alimentam-se da exúvia lexceto a cápsula cefálical e do papel toalha que cobriam os fundos das placas de Petri, nas regiões ainda úmidas, pelo líquido liberado no processo da ecdise. Ao completarem as ecdises as lagartas mantiveram-se com o terço anterior do corpo voltado para trás.

As lagartas no campo foram localizadas nas pági nas inferiores das folhas, quando estavam se alimentando. A mes ma postura corporal em forma de "J", constatada em laboratório, foi observada no campo, só que com maior freqüēncia. Nas horas mais quentes do dia as lagartas permaneceram com o corpo parcialmente dependurado, ou seja, com as regiões da cabeça e tórax voltadas para baixo e presas as folhas através das pernäs abdominais e anais.

Quando tocadas as lagartas adotam, como mecanis mo de defesa, os golpeamentos com a cabeça e o regurgitamento de um liquido de coloração esverdeada não cáustico.

As ecdises em laboratório ocorreram sobre as fo Ihas de papel toalha, e algumas vezes, sobre as folhas de ipê. No campo as ecdises ocorreram nas folhas.

\subsection{PRÉ-PUPA}


pa, tornaram-se bastante agitadas percorrendo toda a placa de Petri e alimentando-se antes da escolha do local, para o estabelecimento definitivo.

Alguns indivíduos peṛmaneceram sobre a folha de papel toalha, mas a maioria procurava penetrar debaixo do pa-pel, próximo da borda da placa ou na região mais interna. Quan do os individuos permaneceram debaixo do papel, observou-se que as lagartas construíram um casulo rudimentar, notando-se per feitamente os individuos no seu interior. Na alameda observou-se também que, as vezes, as Iagartas apresentaram o mesmo tipo de casulo, quando debaixo das folhas.

As pré-pupas observadas apresentaram o comprimento do corpo encurtado, trazendo como conseqüència um maior diāmetro da parte mediana do corpo. As cores de todo o corpo, tornaram-se opacas e mais escuras em relação as lagartas do úl timo instar. As verrugas dorsais e laterais do tórax e do abdo me desapareceram, permanecendo nesses locais apenas a mancha verde-limão, porém escura. A grande verruga dorsal do oitavo segmento degenerou-se, permanecendo em seu lugar um orificio pequeno, alguns indivíduos conservaram as verrugas só que bastante degeneradas; na base da verruga a coloração que outrora fora alaranjada, tornou-se bege-escura. Os colchetes das pernas abdominais e anais, bastante escurecidas, dobraram e volta ram-se para o centro da base de apoio dessas pernas. As cerdas tornaram-se extremamente curtas e ralas na região da cabeça; pernas torácicas e abdominais e extremidade do último segmento 
abdominal, excluindo-se essas regiōes do restante do corpo tor naram-se glabros. Alinha da ecdise foi notada, com maior nitidez, quando os individuos aproximavam-se da ecdise, observando-se 뜨 ma linha fina de coloração bege-escura, partindo da região dor sal do primeiro segmento torácico, logo após a cabeça e estendendo-se até o segundo segmento torácico. Notou-se também o vâ so dorsal em todo o tórax e abdome, apresentando uma coloração bege-escura.

Das 48 pré-pupas oriundas das lagartas que completaram a fase larval, 8 morreram resultando em 83,33\% de via bilidade na fase. A causa maior da mortalidade nessa fase foi possivelmente o fungo verticillium sp., que também atacou as lagartas, sendo que 6 pré-pupas foram atacadas pelo fungo e 2 que morreram por sintomas, cuja causa não foi identificada.

A duração média geral do periodo de pré-pupa foi de 1,94 dias, sendo que 24 individuos tiveram 1 dia de pré-pupa, 211 tiveram 2 dias e 9 tiveram 3 dias (Tabela 15), resultan do um porcentual de 9,83\%, 86,48\% e 3,69\% da freqüēncia de indivíduos, de acordo com a disposição da seqüência apresentada anteriormente (Figura 15). 
Tabela 15 - Duração média, em dias, do período de pré-pupa de R. unimuda. Cuiabá, MT, 1981/82.

\begin{tabular}{cc}
\hline Período de pré-pupa em dias & Quantidade de individuos \\
\hline 1 & 24 \\
2 & 9 \\
3 & 1,94 \\
Média & $1,94 \pm 0,05$ \\
\hline
\end{tabular}

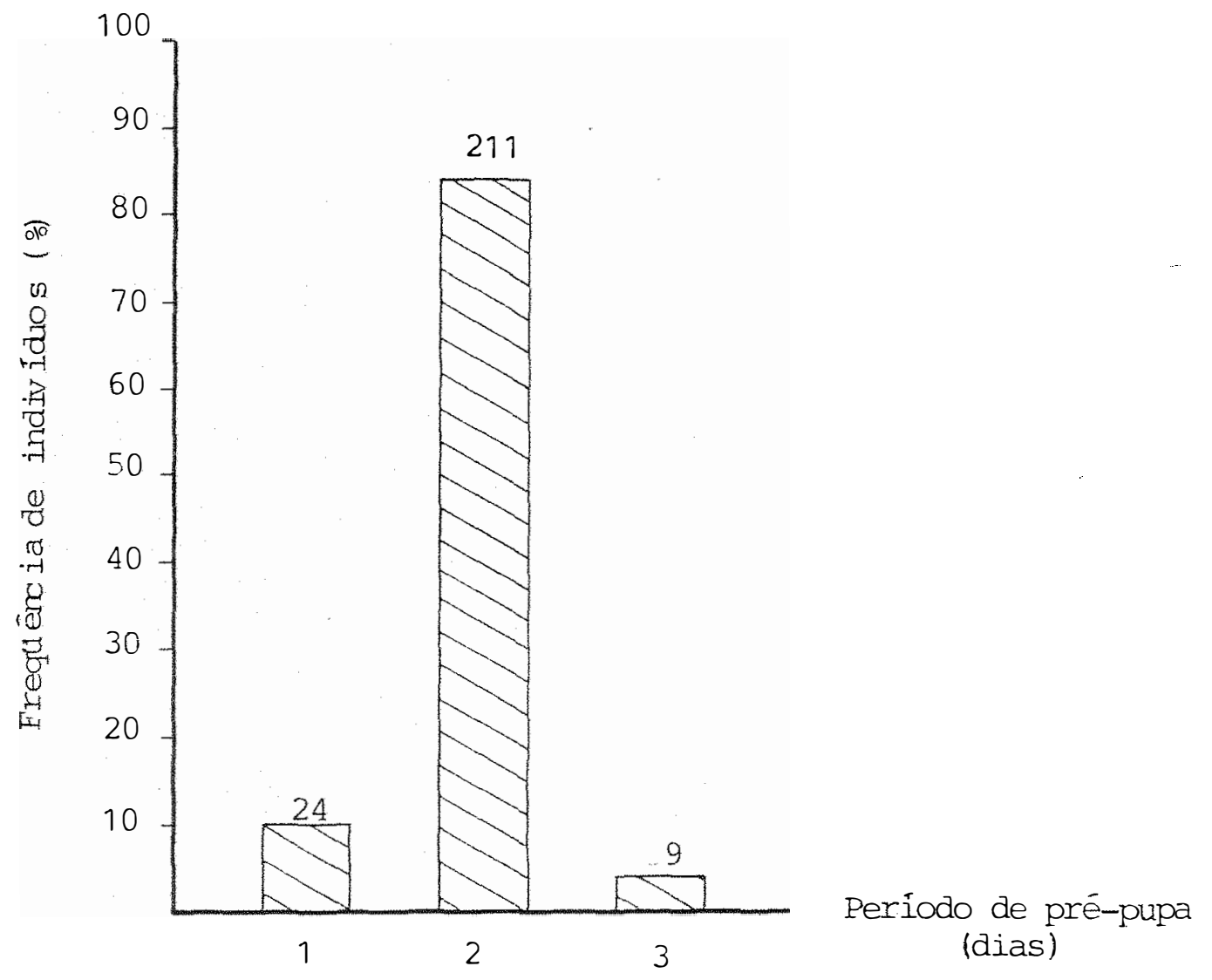

Figura 15 - Período de pré-pupa de R. unimada, conforme a porcentagem e com a respectiva quantidade de individuos (total de 244 pré-pupas). Cuiabá, Mr', 1981/82. 


\subsection{PUPA}

Inicialmente, a coloração de toda a região do tórax e da cabeça apresenta-se verde-limão e com o tegu mento hialino. As asas sāo muito hialinas, o que possibilitou observar os segmentos abdominais situados abaixo. O abdome apresenta-se com coloração amarelo-esverdeada e também com o te gumento hialino, percebendo-se o vaso dorsal percorrendo toda a região tergal. Na região tergal do ültimo segmento abdominal notam-se duas reentrāncias, dispostas horizontalmente ao segmento e com coloração marrom clara ao redor destas cavidades. O dorso dos quatro primeiros segmentos do abdome apresentam $\underline{u}$ ma coloração marrom-clara. As manchas verde-limão encontradas nas bases das verrugas costais das lagartas são mais claras e notadas devido a hialinidade tegumentar.

Todo o abdome passou da coloração amarelo-everdeada, para amarelo-claro e posteriormente marrom-clara, atingindo também a região notal do tórax e de toda a cabeça, sendo as antenas um pouco mais claras. Nesta etapa de escurecimento, apenas as asas e os trés pares de pernas conservam a coloração verde-limão. Posteriormente, todo o corpo apresenta uma co loração marrom-avermelhada, com uma finíssima camada de colora ção esbranquiçada recobrindo a pupa totalmente. As antenas bipectinadas são bem evidenciadas, espirotromba de tamanho reduzido e as asas com altes e baixos podendo se observar algumas nervuras. O corpo é rugoso, sendo esta característica bem evi- 
denciada sob microscópio; os espiráculos possuem os peritremas bem desenvolvidos e da mesma coloração do corpo, sendo que a abertura externa é estreita e de coloração bege-escura. As estruturas genitais dos machos e das fêmeas ficaram bem defini das a partir do quarto dia neste estágio, exceto em alguns pou cos individuos; a estrutura genital do macho fica na parte anterior do nono segmento esternal do abdome e com o aspecto de duas boletas dispostas lado a lado; as fêmeas apresentam uma fenda, disposta longitudinalmente, que tem o seu inicio na par te anterior do oitavo segmento esternal do abdome, indo pelo menos até a metade do segmento. O cremaster com ganchos mais claros do que o resto do corpo e com um pequeno brilho, o núme ro de ganchos contados foi de 24 .

No final da etapa de escurecimento tegumentar a pupa adquire uma coloração café-escura e opaca, distribuída uniformemente por todo o corpo. A camada membranosa que reveste o tegumento torna-se mais densa, na região da cabeça e do tórax; a coloração do revestimento torna-se bege-escura, proporcionando uma camuflagem muito grande na matéria orgânica do sọ 10. A coloração tegumentar é percebida mesmo com o revestimento, porém quando esta película é removida, nota-se que o tegumento apresenta um pequeno brilho. 
Antes da emergēncia dos adultos, as pupas reali zam movimentos abdominais e aumentam de comprimento, chegando- se a notar sensivelmente o alongamento dos anéis abdominais.

Das medições realizadas foram obtidos os seguin tes resultados para o comprimento médio e largura média das pụ pas fémeas: $21,01 \mathrm{~mm}$ e $8,13 \mathrm{~mm}$, respectivamente. Já para as pu pas machos os resultados do comprimento médio e largura média foram: $18,86 \mathrm{~mm}$ e 7,37 mi, respectivamente (Tabela 16). Estatisticamente, as médias apresentadas pelos fēmeas foram maiores do que as médias apresentadas pelos machos.

Dos pesos obtidos das pupas recém-formadas obti veram-se as médias de $0,6617 \mathrm{~g}$ para as fémeas e 0,4788 g para os machos (Tabela 17). Estatisticamente, as fēmeas foram mais pesadas do que os machos. 
Tabela 16 - Comprimento e maior largura, em milímetros, de pupas de $R$. unimuda, segundo o sexo. Cuiabá, MT, 1982.

\begin{tabular}{|c|c|c|c|c|}
\hline \multirow{2}{*}{ Individuo } & \multicolumn{2}{|c|}{ Fêmea } & \multicolumn{2}{|c|}{ Macho } \\
\hline & Compr. (mm) & Larg. (nm) & Compr. (nm) & Iarg. (ntm) \\
\hline 01 & 17,45 & 7,15 & 18,60 & 7,60 \\
\hline 02 & 17,55 & 6,85 & 16,50 & 6,40 \\
\hline 03 & 23,80 & 8,40 & 17,60 & 6,85 \\
\hline 04 & 19,85 & 7,35 & 16,95 & 7,20 \\
\hline 05 & 16,90 & 6,70 & 18,70 & 7,35 \\
\hline 06 & 20,50 & 7,70 & 19,60 & 7,95 \\
\hline 07 & 19,10 & 6,95 & 19,50 & 7,70 \\
\hline 08 & 23,35 & 9,15 & 18,90 & 7,70 \\
\hline 09 & 22,20 & 8,45 & 19,60 & 7,85 \\
\hline 10 & 21,00 & 8,05 & 19,40 & 7,80 \\
\hline 11 & 22,90 & 9,25 & 18,55 & 7,40 \\
\hline 12 & 23,65 & 9,45 & 19,50 & 7,80 \\
\hline 13 & 20,10 & 8,25 & 19,75 & 7,40 \\
\hline 14 & 21,75 & 8,25 & 19,05 & 7,25 \\
\hline 15 & 22,55 & 8,40 & 17,30 & 6,45 \\
\hline 16 & 21,25 & 8,50 & 19,60 & 7,25 \\
\hline 17 & 22,60 & 8,80 & 19,40 & 7,70 \\
\hline 18 & 22,50 & 8,55 & 19,45 & 7,40 \\
\hline 19 & 22,55 & 8,70 & 19,65 & 7,40 \\
\hline 20 & 21,20 & 8,55 & 19,00 & 7,65 \\
\hline 21 & 22,10 & 8,40 & 20,05 & 7,65 \\
\hline 22 & 16,80 & 6,60 & 19,65 & 6,75 \\
\hline 23 & 21,60 & 8,50 & 20,10 & 8,10 \\
\hline 24 & 20,60 & 8,30 & 17,80 & 6,80 \\
\hline 25 & 21,30 & 8,05 & 17,40 & 6,95 \\
\hline Média & 21,01 & 8,13 & 18,86 & 7,37 \\
\hline IC & $21,01 \pm 0,85$ & $8,13 \pm 0,33$ & $18,86 \pm 0,42$ & $7,37 \pm 0,19$ \\
\hline
\end{tabular}


Tabela 17 - Peso, em gramas, de pupas recém-formadas de $R$. unimada, segundo o sexo. Cuiabá, MT, 1983.

\begin{tabular}{|c|c|c|}
\hline \multirow{2}{*}{ Indivĩduo } & \multicolumn{2}{|c|}{ Peso $(g)$} \\
\hline & Fêrnea & Macho \\
\hline 01 & 0,3892 & 0,4709 \\
\hline 02 & 0,3785 & 0,2936 \\
\hline 03 & 0,7741 & 0,3887 \\
\hline 04 & 0,5200 & 0,3680 \\
\hline 05 & 0,3356 & 0,4792 \\
\hline 06 & 0,5698 & 0,5787 \\
\hline 07 & 0,4564 & 0,5485 \\
\hline 08 & 0,9155 & 0,5243 \\
\hline 09 & 0,8841 & 0,6034 \\
\hline 10 & 0,6159 & 0,5519 \\
\hline 11 & 0,8841 & 0,4850 \\
\hline 12 & 1,0100 & 0,5548 \\
\hline 13 & 0,5748 & 0,5306 \\
\hline 14 & 0,7246 & 0,4723 \\
\hline 15 & 0,8019 & 0,3523 \\
\hline 16 & 0,7384 & 0,5048 \\
\hline 17 & 0,8480 & 0,4854 \\
\hline 18 & 0,7799 & 0,5121 \\
\hline 19 & 0,7999 & 0,4651 \\
\hline 20 & 0,6877 & 0,5469 \\
\hline 21 & 0,7296 & 0,4854 \\
\hline 22 & 0,3432 & 0,5069 \\
\hline 23 & 0,6983 & 0,3859 \\
\hline 24 & 0,6607 & 0,3961 \\
\hline Média & 0,6617 & 0,4788 \\
\hline IC & $0,6617 \pm 0,0808$ & $0,4788 \pm 0,0330$ \\
\hline
\end{tabular}


Quanto à duração do período pupal as médias obtidas foram de 20,8 dias para as fêmeas e 21,4 dias para os mą chos (Tabela 18). Estatisticamente, a longevidade das fêmeas não diferiu da longevidade dos machos. A média geral, para am bos os sexos foi de 21,1 dias.

Das 40 pupas oriundas das pré-pupas, 4 morreram resultando em uma viabilidade de 90\% nesta fase. A causa da mortalidade foi, possivelmente, o fungo verticillium sp.

$\mathrm{Na}$ alameda e no cerrado as pupas foram encontra das debaixo das folhas secas caídas ou no meio da matéria orgâ nica em decomposição, porém superficialmente e nunca enterrada no solo. Na alameda os individuos às vezes ficavam alojados de baixo do calçamento. Observou-se que, nas coletas, alguns indi víduos foram encöntrados muito próximos uns dos outros, mas a grande maioria foi encontrada isoladamente embora, sempre nas proximidades da árvore onde as lagartas alimentaram-se e den tro do diâmetro da copa. 
Tabela 18 - Duração média, en dias, do período pupal de R. unimuda, segun do o sexo das pupas. Cuiabá, MT, 1982.

\begin{tabular}{|c|c|c|}
\hline \multirow{2}{*}{$\begin{array}{l}\text { Indivíduo } \\
\text { nümero }\end{array}$} & \multicolumn{2}{|c|}{ Período pupal (dias) } \\
\hline & Fêmea & Macho \\
\hline 01 & 20 & 21 \\
\hline 02 & 22 & 23 \\
\hline 03 & 23 & 21 \\
\hline 04 & 27 & 22 \\
\hline 05 & 21 & 23 \\
\hline 06 & 21 & 23 \\
\hline 07 & 24 & 23 \\
\hline 08 & 25 & 21 \\
\hline 09 & 23 & 22 \\
\hline 10 & 24 & 25 \\
\hline 11 & 20 & 25 \\
\hline 12 & 21 & 22 \\
\hline 13 & 20 & 21 \\
\hline 14 & 25 & 22 \\
\hline 15 & 19 & 24 \\
\hline 16 & 19 & 25 \\
\hline 17 & 19 & 27 \\
\hline 18 & 25 & 20 \\
\hline 19 & 18 & 20 \\
\hline 20 & 23 & 19 \\
\hline 21 & 19 & 24 \\
\hline 22 & 19 & 20 \\
\hline 23 & 19 & 21 \\
\hline 24 & 20 & 18 \\
\hline 25 & 18 & 18 \\
\hline 26 & 18 & 18 \\
\hline 27 & 18 & 17 \\
\hline 28 & 18 & 19 \\
\hline 29 & 24 & 18 \\
\hline 30 & 20 & 21 \\
\hline $3 ?$ & 18 & 19 \\
\hline 32 & 22 & 23 \\
\hline 33 & 18 & 20 \\
\hline 34 & 20 & 20 \\
\hline 35 & 19 & 21 \\
\hline 36 & 19 & 25 \\
\hline Media & 20,8 & 21,4 \\
\hline IC & $20,8 \pm 0,9$ & $21,4 \pm 0,8$ \\
\hline
\end{tabular}




\title{
4.6. AdULTO
}

\subsubsection{EMERGÊNCIA}

\begin{abstract}
As observações dos horārios de emergẽncia foram feitas com individuos trazidos da alameda e sob iluminação artificial, considerando-se 30 individuos para cada sexo.

Inicialmente, as pupas realizaram alguns movimentos e alongamento dos anéis abdominais. os adultos, ao sairem pela parte anterior da pupa, expeliram um líquido através da parte abdominal posterior, cuja coloração foi de bege-clara ao bege de tonalidade média, sendo também. constatado a colora ção cor-de-rosa.
\end{abstract}

Para os machos verificou-se que o inicio da emergência ocorreu as 11:55 horas, terminando as 20:00 horas. Embora a emergência tenha sido iniciada durante o periodo de luz, a maioria dos machos adultos emergiram sob o periodo de escuridão, pois no perído compreendido entre as 17:38 e 19:55 horas emergiram 10 individuos e no período compreendido entre 18:56 e 20:09 horas emergiram 11 individuos, contra 9 indivi duos dos quatro primeiros períodos reunidos (Tabela 19). Expressando-se a quantidade de individuos/horário de emergêncìa, em termos de porcentagem foram obtidos os valores de 10,0;3,3; 0,$0 ; 16,7 ; 33,3$ e 36,7\%, respectivamente para o 1\%, 2\%, 3\%,4\%, 5\% e 6? periodos (Figura 16). 
Tabela 19 - Quantidade de adultos emergidos de R. unimuda, de acordo com o horário e o sexo. Cuiabá, MT, 1981/82.

\begin{tabular}{ccccc}
\hline \multicolumn{2}{c}{ Macho } & & \multicolumn{2}{c}{ Fêmea } \\
\cline { 1 - 1 } \cline { 5 - 5 } Classes (hora) & Frequência & & Classes (hora) & Frequéncia \\
\hline $11: 55-13: 19$ & 3 & & $9: 00-10: 54$ & 5 \\
$13: 20-14: 43$ & 1 & $10: 55-12: 48$ & 0 \\
$14: 44-16: 07$ & 0 & & $19: 49-14: 42$ & 6 \\
$16: 08-17: 31$ & 5 & $14: 43-16: 36$ & 4 \\
$17: 32-18: 55$ & 10 & $16: 37-18: 30$ & 8 \\
$18: 56-20: 19$ & 11 & $18: 31-20: 24$ & 7 \\
\hline
\end{tabular}

Para as fēmeas o início da emergēncia deu-se às 9:00 horas e estendeu-se até às 19:52 horas, ou seja, o início ocorreu antes do horário observado para os machos porém, o tér mino foi praticamente o mesmo. Observou-se, também, para as fémeas que a emergēncia ocorreu predominantemente nos períodos de iluminação, com uma maior quantidade de emergentes nos dois últimos, períodos e sem nenhum no segundo período. Obtendo-se as seguintes quantidades de fémeas emergidas/horário de emer gēncia, expressas em porcentagem 16,$7 ; 0,0 ; 20,0 ; 13,3 ; 26,7$ e

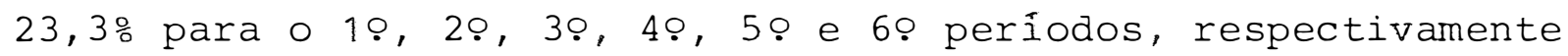
(Tabela 19 e Figura 22). 

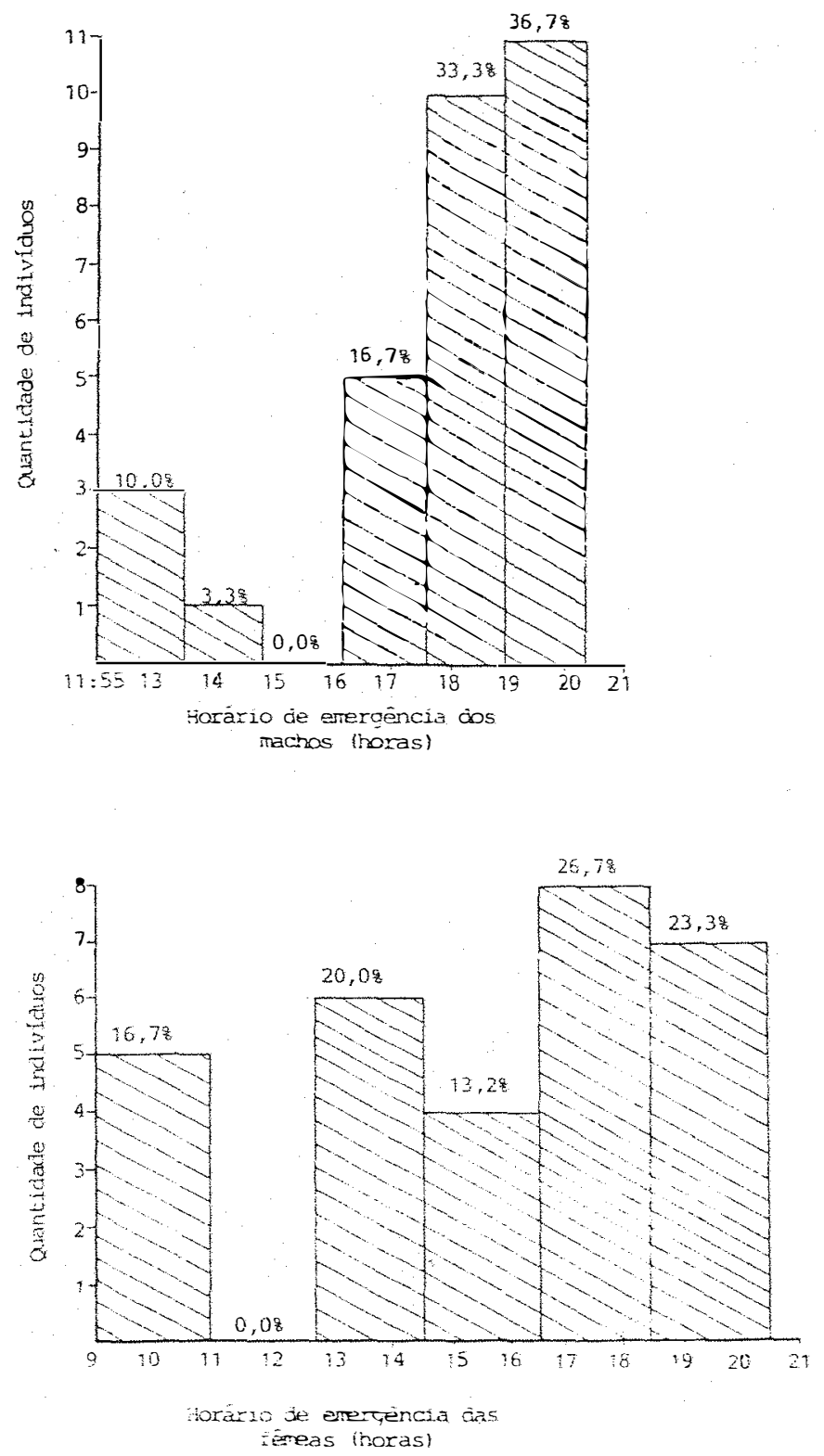

Figura 16 - Freqüēncias de emergẽncia dos adultos de R. unimoda, en porcen tagem, de acordo com o horário e o sexo (total de 30 individuos para cada sexo). Cuiabá, MT, 1981/82. 


\subsubsection{RAZÃO SEXUAL}

Foram observadas 434 pupas das coletas realizadas no campo e 256 pupas viáveis provenientes de lagartas criadas em laboratório.

As pupas provenientes do campo originaram 274 machos e 160 fémeas, resultando em uma razão sexual de 0,369. As pupas produzidas em laboratório originaram 157 machos e 99 fémeas, resultando em uma razão sexual de 0,388.

A proporção sexual obtida para os individuos de campo foi de 1,713 machos : 1 fêmea e para os indivíduos de laboratório foi de 1,586 machos : 1 fêmea, ou seja, uma proporção aproximada de 1,7 machos : '1 fémea para o primeiro caso e uma proporção aproximada de 1,6 machos : 1 fêmea para o segundo caso.

$$
\text { Considerando-se todos os individuos coletados }
$$
no campo e provenientes da criação em laboratórios a razão sexual foi de 0,375 e a proporção sexual de 1,7 machos : 1 fémea.

\subsubsection{CÓPULA}

Considerou-se o período de pré-cópula como sen do o intervalo de tempo compreendido entre a emergência e a pri meira cópula da fémea adulta. A média obtida para este período foi de 1,7 dias, sendo que a variação foi de 1 a 3 dias (Tab.20). 
Tabela 20 - Duração, en dias do período de pré-cópula, em R. unimoda. Cuia bá, MT, 1983.

\begin{tabular}{ccc}
\hline Pré-cópula (dias) & Freqüéncia & Total \\
\hline 1 & 12 & 12 \\
2 & 19 & 38 \\
3 & 1 & 3 \\
\hline Total & 32 & 53 \\
\hline mp $=1,7$ & & \\
\hline $\mathrm{C}=1,7 \pm 0,2$ & & \\
\hline
\end{tabular}

o período de pré-cópula que ocorreu com maior freqüência foi o de 2 dias com 59,38\% das fêmeas, com 1 dia ocorreu em 37,50\% e com 3 dias em 3,12\% das fêmeas (Figura 17).

As fêmeas copularam uma única vez, mesmo quando se colocou mais de um macho por uma fémea. A cópula geralmente foi iniciada após às 5:00 horas da manhã e antes de atingir o período de luminosidade, embora algumas cópulas fossem inicia das neste período, sem contudo exceder os primeiros 32 minutos; a duração média das cópulas observadas foi de 716,0 minutos e sem interrupção (Tabela 21). 
Tabela 21 - Durações dos períodos de cópulas, em minutos, obtidos de adultos de R. unimada. Cuiabā, MT, 1983.

\begin{tabular}{|c|c|c|c|}
\hline \multirow{2}{*}{$\begin{array}{l}\text { Casal } \\
\text { número }\end{array}$} & \multicolumn{2}{|c|}{ cópula } & \multirow{2}{*}{$\begin{array}{c}\text { Duração total } \\
\text { (minuto) }\end{array}$} \\
\hline & Início (hora) & Término (hora) & \\
\hline 01 & $6: 30$ & $14: 50$ & 500 \\
\hline 02 & $6: 05$ & $19: 15$ & 790 \\
\hline 03 & $5: 34$ & $19: 06$ & 812 \\
\hline 04 & $5: 33$ & $18: 11$ & 758 \\
\hline 05 & $5: 34$ & $17: 36$ & 722 \\
\hline 06 & $6: 00$ & $18: 36$ & 756 \\
\hline 07 & $6: 30$ & $18: 30$ & 720 \\
\hline 08 & $6: 00$ & $17: 40$ & 700 \\
\hline 09 & $5: 29$ & $18: 35$ & 786 \\
\hline 10 & $5: 16$ & $15: 00$ & 584 \\
\hline 11 & $5: 30$ & $17: 50$ & 740 \\
\hline 12 & $6: 04$ & $18: 30$ & 746 \\
\hline 13 & $5: 50$ & $18: 28$ & 798 \\
\hline 14 & $5: 50$ & $18: 32$ & 762 \\
\hline 15 & $6: 32$ & $18: 15$ & 703 \\
\hline 16 & $5: 53$ & $17: 58$ & 725 \\
\hline 17 & $6: 32$ & $18: 32$ & 721 \\
\hline 18 & $6: 40$ & $18: 38$ & 718 \\
\hline 19 & $5: 53$ & $16: 47$ & 654 \\
\hline 20 & $5: 50$ & $18: 20$ & 750 \\
\hline 21 & $6: 00$ & $18: 24$ & 744 \\
\hline 22 & $5: 40$ & $9: 30$ & 230 \\
\hline 23 & $5: 53$ & $18: 35$ & 762 \\
\hline 24 & $6: 00$ & $18: 21$ & 741 \\
\hline 25 & $5: 50$ & $22: 09$ & 979 \\
\hline Média & & & 715,0 \\
\hline$I C$ & & & $716,0 \pm 54,0$ \\
\hline
\end{tabular}




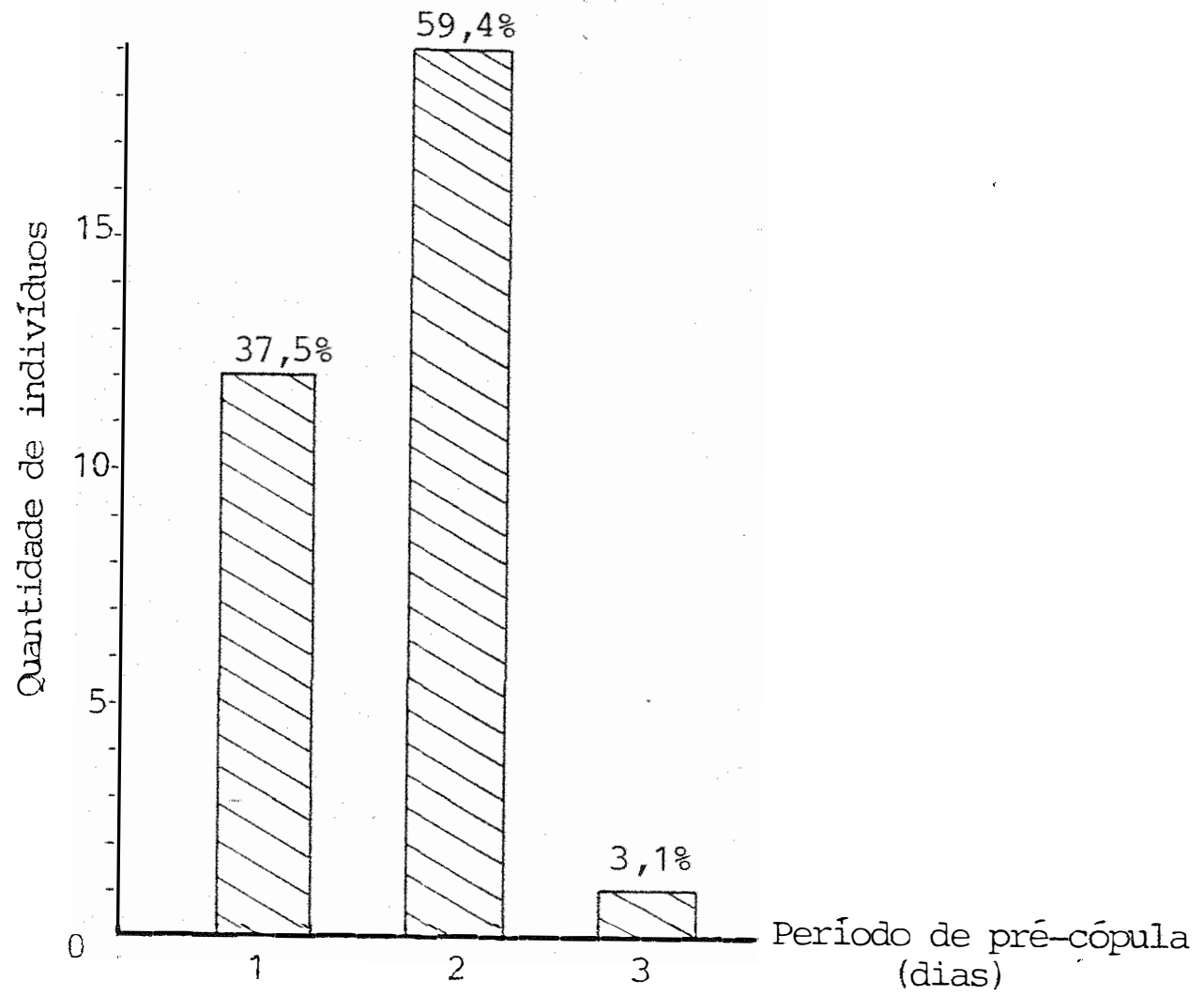

Figura 17 - Período de pré-cópula de R. unimoda, conforme a quantidade e porcentagen dos indiviauos (total de 32 fêmeas). Cuiabá, MT, 1983. 


\section{$4,6,4$. POSTURA}

As fêmeas copuladas e que fizeram posturas, apresentaram um período médio de pré-postura de 1,2 dias TTabela 22). Considerou-se como período de pré-postura o tempo compreendido entre o término da cópula e a primeira postura. Das 33 fêmeas observadas, $8(24,2 \%)$ iniciaram suas posturas no período de escuridão e no mesmo dia em que terminaram suas cópulas; a maioria das fêmeas iniciou as posturas até com 1 dia, ou seja, 23 fêmeas $(69,7 \%)$; para os períodos de 2, 3 e 4 dias de pré-postura foram obtidas as porcentagens de $21,2 \%, 6,1 \%$ e 3,0\%, respectivamente (Figura 18).

o período de postura apresentou uma duração média de 1,9 dias, variando de 1 a 5 dias (Tabela 23). Das 33 fẹ meas observadas, $21(63,6 \%)$ apresentaram 1 dia de período de postura, demonstrando uma forte tendência para ovipositarem em

Tabela 22 - Duração, en dias, do perí̃odo de pré-postura em R. unimuda. Cuia bà, MT, 1983.

\begin{tabular}{|c|c|c|}
\hline Período de pré-postura (dia) & Freqüuencia & Total \\
\hline $\begin{array}{l}0^{*} \\
1 \\
2 \\
3 \\
4\end{array}$ & $\begin{array}{r}8 \\
15 \\
7 \\
2\end{array}$ & $\begin{array}{r}0 \\
15 \\
14 \\
6 \\
4\end{array}$ \\
\hline TOTAL & 33 & 39 \\
\hline
\end{tabular}

* postura iniciada antes de completar 1 äia $\operatorname{mp}=1,2 ; \quad I C=1,2 \pm 0,4$. 
Tabela 23 - Duração, em dias, de período de postura em R. unimoda. Cuiabá, MT, 1983.

\begin{tabular}{ccc}
\hline $\begin{array}{c}\text { Periodo de postura } \\
\text { (dias) }\end{array}$ & Frequéncia & Total \\
\hline 1 & 21 & 21 \\
2 & 2 & 4 \\
3 & 5 & 15 \\
4 & 3 & 12 \\
5 & 2 & 10 \\
\hline Total & 33 & 62 \\
\hline Média & 1,9 & \\
IC & $1,9 \pm 0,5$ & \\
\hline
\end{tabular}

apenas um dia, as demais apresentaram 2, 3, 4 e 5 dias de posturas correspondendo a $6,1 \% ; 15,1 \% ; 9,1 \%$ e $6,1 \%$, respectivamen te (Figura 19).

Todas as fémeas iniciaram suas posturas sob o periodo de escuridão, mas continuaram no período de luminosidade.

Quanto a quantidade de posturas observou-se que, nas 33 fémeas estudadas, a maioria realizou uma única postura representando $63,6 \%$ das fémeas e, para os individuos que efetuaram 2, 3 e 4 posturas, as porcentagens obtidas foram de 21, 2\%; 9,1\% e 6,1\%, respectivamente (Figura 20). 


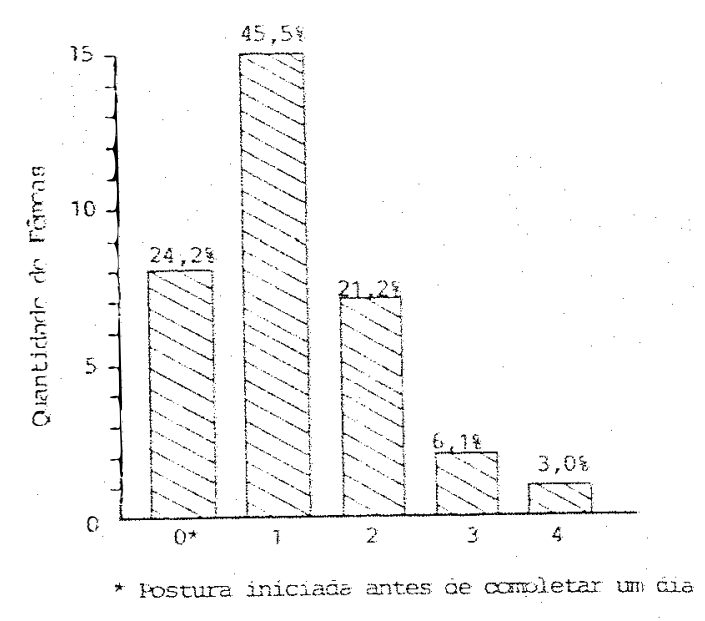

Fig. 18 - Período de pré-postura das fêmeas de $R$. unimoda, con forme a guantidade e porcentā ger dos individuos total de 33 fêmeas). Cuiabá, MT, 1983.

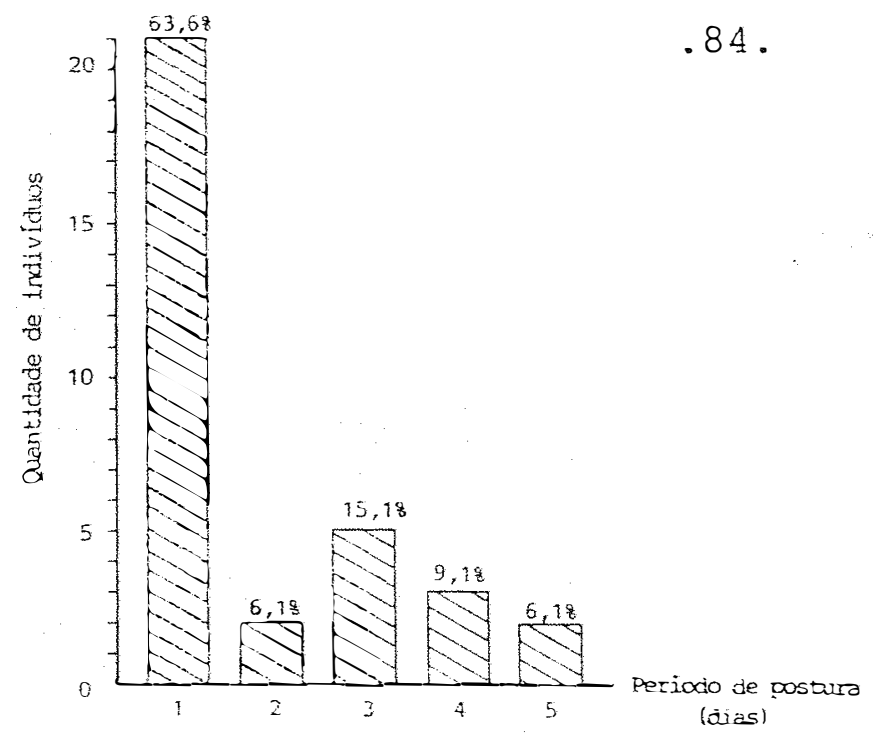

Fig. 19 - Período de postura de $\bar{k}$. unimo da, conforme a quantidade e porcentagem dos individuos (total de 33 fémeas). Cuiabá, MT, 1983.

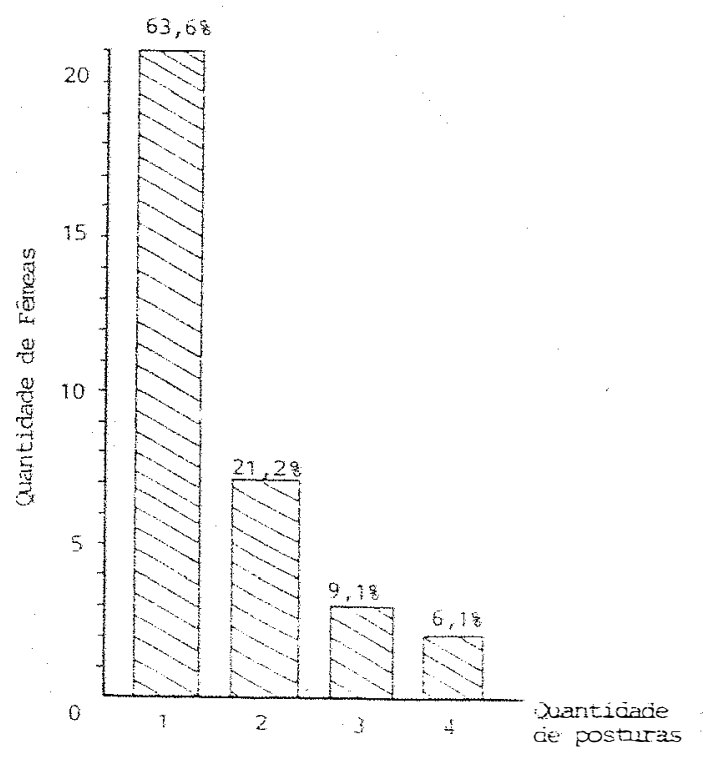

Fig. 20 - Quantidade de posturas efetuados por fêmeas de $R$. unimoda, corn as respectivas quantidades de fêmeas e porcentagens (total de 33 fêmeas). Cuiabá, Mr, 1983. 
Embora o número máximo de posturas tenha sido de 4 e o período de postura com o máximo de 5 dias, isto deve- se ao fato de que as fèmeas durante o periodo de postura não ovipositarem em dias consecutivos sendo constatados de 1 a 3 interrupções.

As fēmeas que efetuaram mais de uma postura colocaram a maioria dos ovos na primeira postura. Para as fémeas que apresentaram 2 posturas, a quantidade de ovos da primeira foi de $65 \%$ e, conseqüentemente, 35\% para a segunda. Para as fē meas que apresentaram 3 posturas, a quantidade de ovos da primeira foi de $70,4 \%$, a da segunda e terceira apresentaram 18,3\% e 11,3\%, respectivamente. Para as fēmeas que apresentaram 4 pos turas as quantidades de ovos ovipositados expressos em porcentagens foram de $73,6 \%, 14,0 \%, 10,2 \%$ e 2,2\% para a primeira, se gunda, terceira e quarta postura, respectivamente.

o período médio de pós-postura das fêmeas foi de 2,1 dias (Tabela 24). Sendo que as 33 fêmeas, 9,1\% não chega ram a completar 1 dia deste periodo e as demais tiveram 1, 2, 3, 4 e 5 dias de pós-postura representando as porcentagens de $27,3 \%, 27,3 \%, 24,2 \%, 9,1 \%$ e 3,0\%, respectïvamente (Eigura 21) . 
Tabela 24 - Duração, en dias, do período de pós-postura en fêmeas de R. unimoda, Cuiabá, MT, 1983.

\begin{tabular}{ccc}
\hline Períảo de pós-postura (dias) & Frequéncia & Total \\
\hline 0 & 3 & 00 \\
1 & 9 & 09 \\
2 & 9 & 18 \\
3 & 8 & 24 \\
4 & 3 & 12 \\
5 & 1 & 05 \\
Total & 33 & 68 \\
\hline IC $=2,1 \pm 0,4$ & & \\
\hline
\end{tabular}




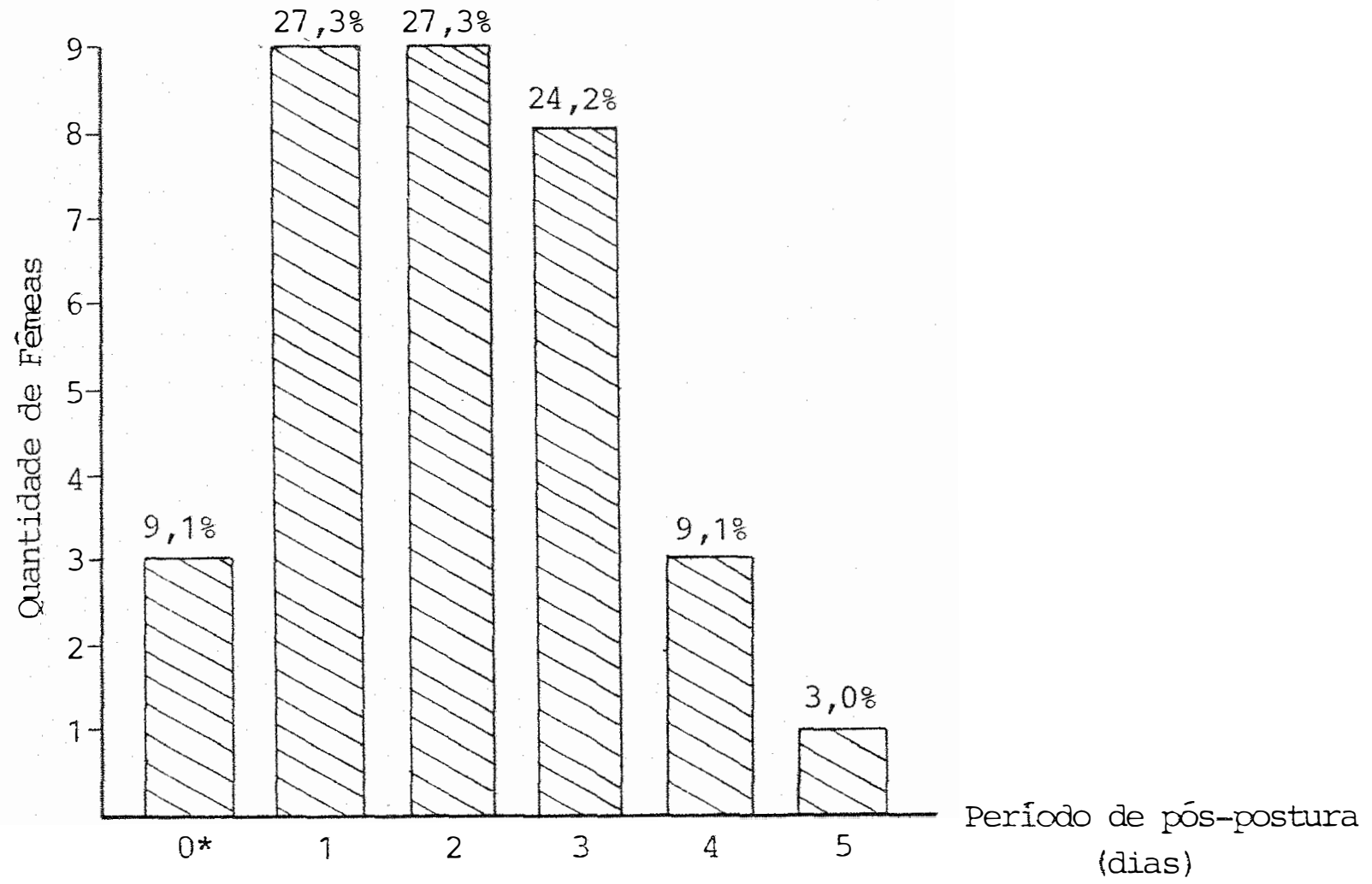

* morreram antes de completarem um dia de pós-postura

Figura 21 - Periodo de pós-postura das fémeas de R. unimuda, conforme a quantidade e porcentagen das fêmeas. Cuiabá, MTr, 1983. 


\subsubsection{LONGEVIDADE}

As longevidadés médias de fémeas e machos que se acasalaram foram 5,6 e 4,7 dias, respectivamente (Tabela 25). Estatisticamente as fêmeas apresentaram uma longevidade maior que a dos machos.

As longevidades médias de fēmeas e machos que não se acasalaram foram de 5,7 e 4,5 dias, respectivamente (Tâ bela 25). Estatisticamente as fêmeas apresentaram uma longevidade maior que a dos machos.

Estatistïcamente, as médias das longevidades das fêmeas acasaladas e não acasaladas não diferiram, o mesmo ocor rendo com as médias das longevidades dos machos acasalados e não acasalados. A longevidade geral média para as feemeas aca saladas e não acasaladas foi de 5,6 dias, para os machos acasa lados e não acasalados a média geral foi de 4,6 dias.

Mesmo quando se compararam as médias das longevidades das fêmeas acasaladas com os machos não acasalados, a diferença foi significativa estatisticamente, ou seja, as fémeas apresentaram uma longevidade maior do que os machos. Quan do se compararam as médias das longevidades das fêmeas não acạ saladas com os machos acasalados, estatisticamente a diferença foi significativa, portanto as fémeas apresentaram uma longevi dade maior do que a dos machos. 
Tabela 25 - Longevidade, ern dias, de adultos fêmeas e machos de R. unímoda, acasalados e não acasalados. Cuiabá, MT, 1983.

\begin{tabular}{|c|c|c|c|c|}
\hline \multirow{2}{*}{$\begin{array}{l}\text { Adultos } \\
\text { número }\end{array}$} & \multicolumn{2}{|c|}{$\begin{array}{l}\text { Iongevidade de acasalados } \\
\text { (dias) }\end{array}$} & \multicolumn{2}{|c|}{$\begin{array}{l}\text { Iongevidade de não acasalados } \\
\text { (dias) }\end{array}$} \\
\hline & Fêmea & Macho & Fêmea & Macho \\
\hline 01 & 7 & 7 & 3 & 4 \\
\hline 02 & 7 & 6 & 5 & 5 \\
\hline 03 & 7 & 6 & 11 & 6 \\
\hline 04 & 5 & 5 & 5 & 4 \\
\hline 05 & 7 & 5 & 5 & 6 \\
\hline 06 & 7 & 5 & 9 & 4 \\
\hline 07 & 6 & 4 & 8 & 6 \\
\hline 08 & 4 & 5 & 6 & 3 \\
\hline 09 & 5 & 3 & 7 & 3 \\
\hline 10 & 8 & 5 & 4 & 3 \\
\hline 11 & 6 & 4 & 4 & 4 \\
\hline 12 & 5 & 5 & 7 & 4 \\
\hline 13 & 7 & 5 & 6 & 4 \\
\hline 14 & 3 & 4 & 6 & 5 \\
\hline 15 & 5 & 4 & 8 & 3 \\
\hline 16 & 6 & 4 & 7 & 4 \\
\hline 17 & 7 & 4 & 7 & 3 \\
\hline 18 & 5 & 5 & 10 & 4 \\
\hline 19 & 6 & 4 & 7 & 4 \\
\hline 20 & 6 & 5 & 6 & 4 \\
\hline 21 & 5 & 7 & 5 & 5 \\
\hline 22 & 8 & 4 & 6 & 3 \\
\hline 23 & 5 & 4 & 6 & 5 \\
\hline 24 & 5 & 3 & 2 & 5 \\
\hline 25 & 3 & 6 & 4 & 6 \\
\hline 26 & 7 & 4 & 5 & 3 \\
\hline 27 & 3 & 4 & 2 & 5 \\
\hline 28 & 3 & 5 & 4 & 8 \\
\hline 29 & 5 & 6 & 3 & 7 \\
\hline 30 & 4 & 4 & 2 & 5 \\
\hline Média & 5,6 & 4,7 & 5,7 & 4,5 \\
\hline IC & $5,6 \pm 0,6$ & $4,7 \pm 0,4$ & $5,7 \pm 0,8$ & $4,5 \pm 0,5$ \\
\hline
\end{tabular}




\subsubsection{CARACTERIZACĀO MORFOLD́GICA}

Macho e fêmea: cor do corpo verde claro, unifor memente distribuído, exceto as regiões dorso-laterais do tórax que se apresentam com tonalidades mais claras (tégulas).

Cabeça (macho e fêmea): apresenta-se de forma arredondada e mais estreita do que o tórax. Excetuando-se as antenas, olhos compostos e espirotxomba rudimentar, todo o res tante e densamente revestido de cerdas piliformes. Olhos com postos negros e, em alguns indivíduos, a presença de listras brancas distribuidas irregularmente e observada somente sob o microscópio formando polígonos de formas irregulares (Figura 28). Antenas bipectinadas da mesma coloração do corpo porèm com cerdas enfileiradas (pécten) de coloração alaranjada; comprimento antenal é de aproximadamente $1 / 3$ da extensão da margem costal das asas anteriores. Palpos labiais projetados para frente em relação ao fronto-clípeo.

Tórax (macho e fêmea): todo o tórax recoberto de escamas piliformes. Asas posteriores com duas faixas dorsais escuras e dispostas transversalmente, sendo que as mais inter nas iniciam-se na parte mediana da margem anal e terminam na parte média da margem costal; a outra mais próxima da margem externa, inicia-se na margem anal e termina na margem costal próxima da margem externa. Esta última faixa é mais nitida e observada em todos individuos, ao passo que a outra é pouco niti da e geralmente é encontrada apenas uma parte dela. Essas fai 
xas continuam com as mesmas disposições nas asas anteriores po rém, entre elas surge uma outra faixa que se inicia na margem anal caminhando para a margem costal, mas ao atingir a parte me diana da asa sofre uma bifurcação e transforma-se em um círculo, que quase toca a margem costal da asa.anterior. Ventralmente, as asas anteriores e posteriores exibem uma coloração semelhante à face dorsal, porém as anteriores possuem uma coloração esbran quiçada em toda a extensão da margem anal, estendendo-se até a altura de $1 / 3$ da margem externa. Todas as asas possuem cerdas piliformes em suas margens externas e anais. Apenas um frênulo, robusto e bem desenvolvido fara cada uma das asas posteriores dos machos, nas fêmeas da base de apoio do frênulo partem diversas cerdas, frágeis e mais curtas do que o frênulo dos machos. As pernas encontram-se densamente revestidas de escamas, nas partes internas dos fémures surgem escamas piliformes enfileiradas e bern desenvolvidas, sendo também encontradas recobrindo a face interna das tíbias anteriores (strigil); os tarsos são pentāmeros e honōmeros, o pós-tarso com 2 garras simples, um aróI io negro entre as garras também de coloração negra na parte apical e cas tanho na base, um pulvilo próximo a cada garra tarsal e um único pêlo saindo da parte média e externa do último tarsómero.

Abdome: densamente recoberto por escamas mais longas do que as encontradas nas asas. Nas fêmeas o abdome é vo lumoso e cilindróide, nos machos menores do que o das fêmeas e com a forma tendente para a conóide (Figura 22), com um tufo de escamas piliformes bem desenvolvidas na extremidade (Fig. 23). 
Nas fêmeas toda a extremidade é recoberta por escamas (Figura 24), difi cultando a localização dos orifícios anal e genital, nos machos, embora com o tufo de escamas piliformes, chega-se a notar parte dos "gnathos" em forma de arco esclerosado (Figura 23). DOGNIN (1923) fez a descrição baseando-se apenas em um exemplar macho e de coloração diferente da descrita anteriomente. Provavelmente, o autor não trabalhou com exemplar morto recentemente, a carretando assim em uma descrição errônea da coloração, pois os adultos de $R$. unimoda apresentam uma facilidade muito grande para alte rar a sua cor depois de mortos.

Estatisticamente, as fêmeas apresentaram envergardura média das asas anteriores maior do que a dos machos (Tabela 26). 
.93.

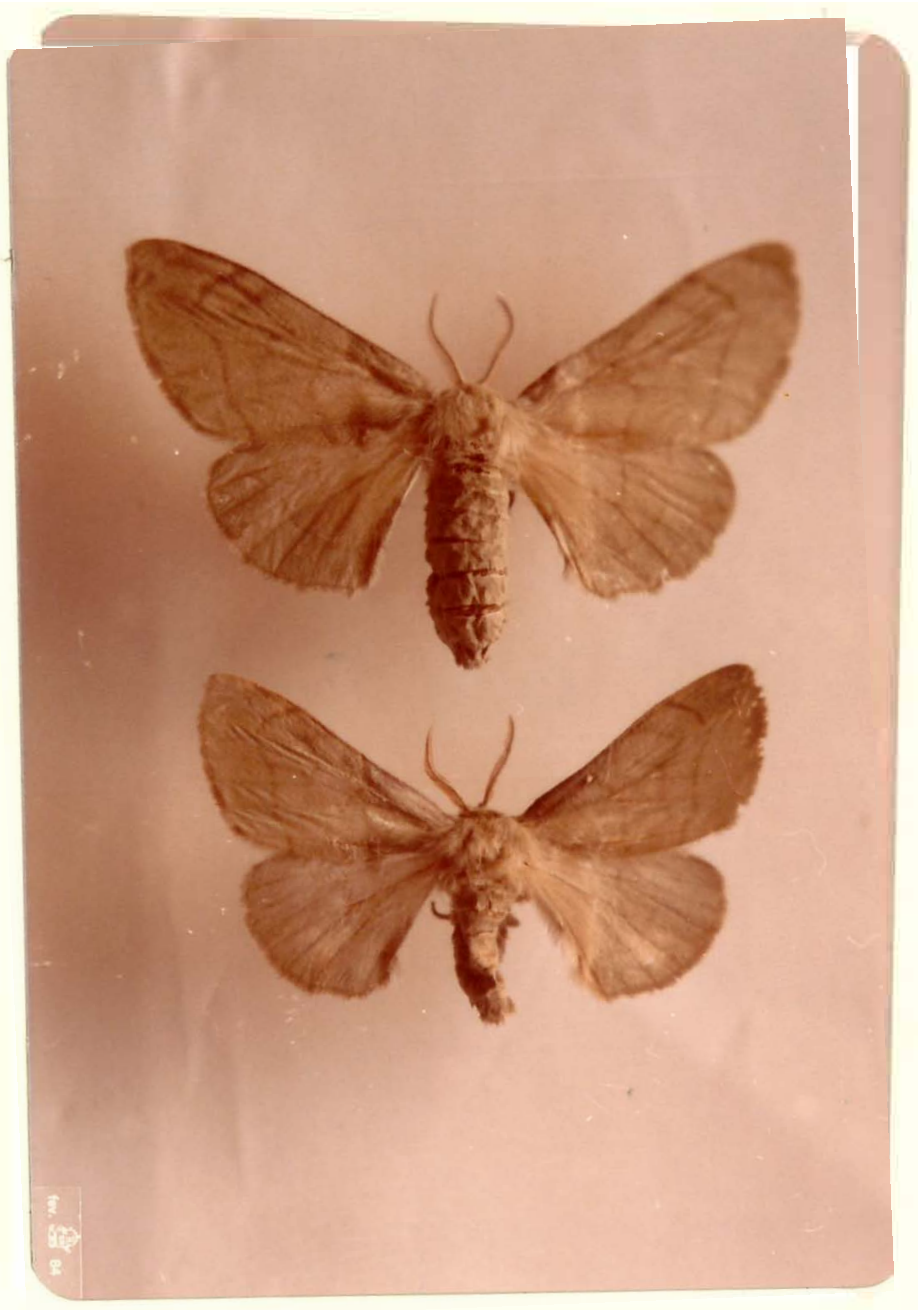

Figura 22 - Adultos fêmea (superior) e macho (inferior) de R. unimuda (aumento $1,6 \mathrm{X}$ ) . 
.94.

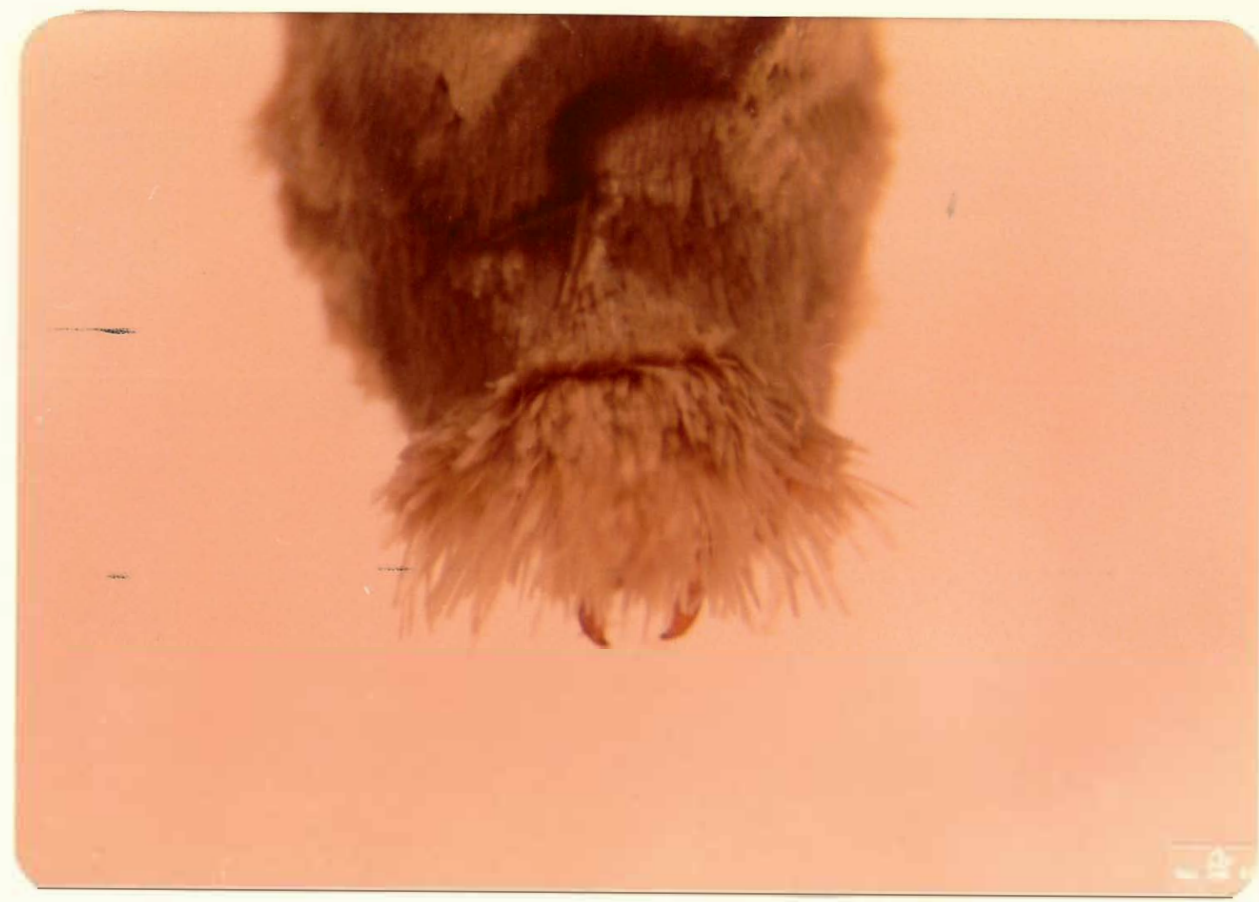

Figura 23 - Parte terminal do abdame de um adulto (macho) de R. unimoda (aumento 25X).

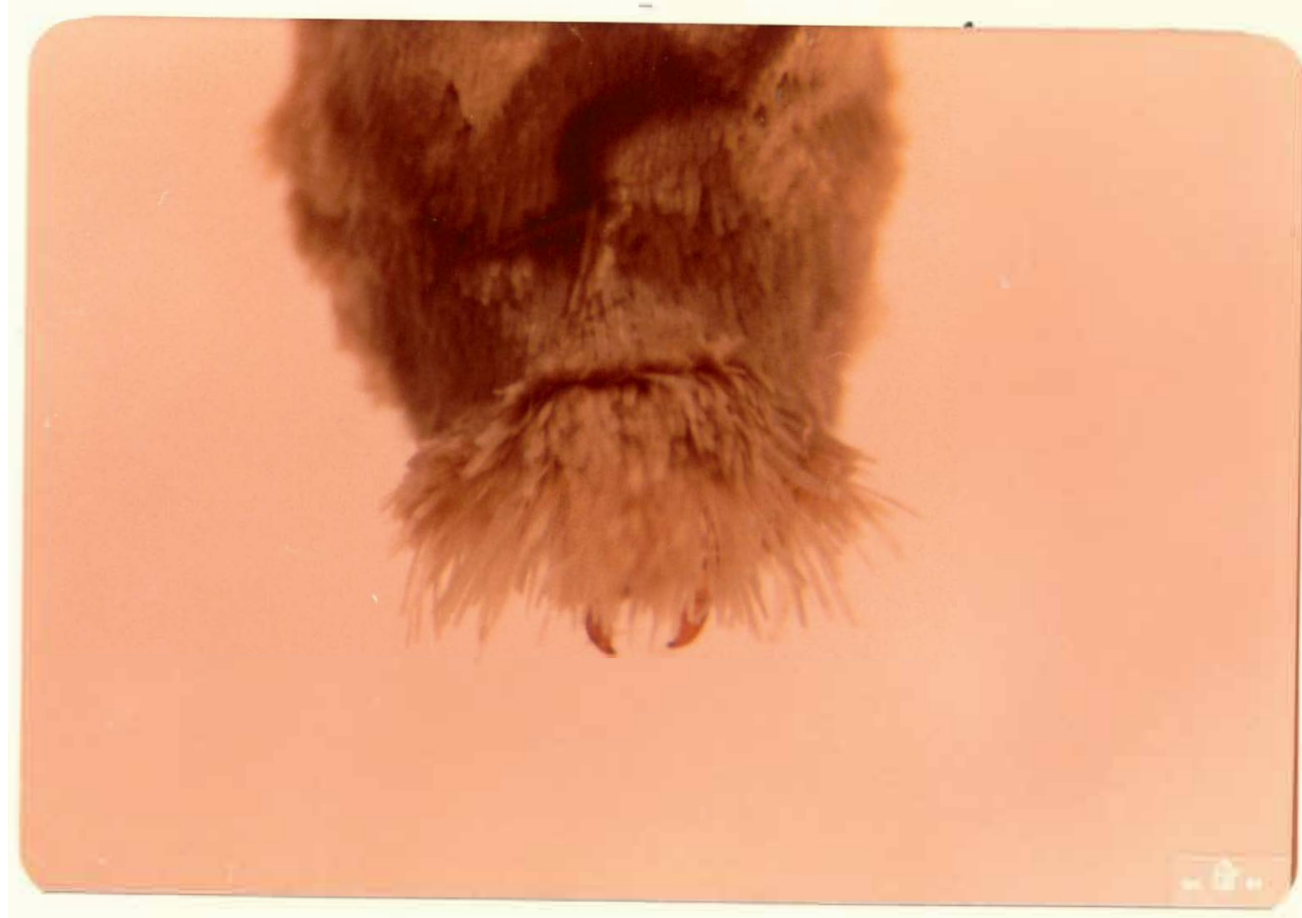

Figura 24-Parte terminal do abdome de um adulto (fêmea) de R. unimoda (aumento 12X). 
Tabela 26 - Envergadura, em milimetros, das asas anteriores de R. unimuda, de acordo com o sexo. Cuiabá, MT, 1981/82.

\begin{tabular}{|c|c|c|}
\hline \multirow{2}{*}{$\begin{array}{l}\text { Individuo } \\
\text { nümero }\end{array}$} & \multicolumn{2}{|c|}{ Envergadura (mm) } \\
\hline & Fênea & Macho \\
\hline 01 & 46,50 & 38,90 \\
\hline 02 & 48,55 & 40,00 \\
\hline 03 & 39,60 & 38,90 \\
\hline 04 & 45,30 & 33,30 \\
\hline 05 & 47,50 & 39,55 \\
\hline 06 & 47,05 & 36,55 \\
\hline 07 & 41,90 & 32,35 \\
\hline 08 & 51,90 & 35,85 \\
\hline 09 & 43,20 & 38,70 \\
\hline 10 & 51,20 & 41,20 \\
\hline 11 & 45,10 & 42,80 \\
\hline 12 & 38,30 & 39,00 \\
\hline 13 & 50,50 & 40,00 \\
\hline 14 & 42,70 & 38,90 \\
\hline 15 & 44,80 & 42,60 \\
\hline 16 & 47,30 & 42,30 \\
\hline 17 & 43,10 & 31,95 \\
\hline 18 & 43,75 & 36,10 \\
\hline 19 & 51,45 & 34,80 \\
\hline 20 & 48,80 & 35,15 \\
\hline 21 & 48,70 & 35,30 \\
\hline 22 & 45,00 & 38,00 \\
\hline 23 & 41,85 & 32,20 \\
\hline 24 & 42,65 & 34,15 \\
\hline 25 & 45,85 & 33,20 \\
\hline 26 & 41,10 & 37,10 \\
\hline 27 & 45,90 & 34,95 \\
\hline 28 & 42,25 & 34,90 \\
\hline 29 & 41,20 & 37,30 \\
\hline 30 & 41,20 & 37,10 \\
\hline 31 & 42,40 & 33,15 \\
\hline 32 & 42,85 & 34,35 \\
\hline Média & 44,98 & 36,90 \\
\hline IC & $44,98 \pm 1,28$ & $36,90 \pm 1,13$ \\
\hline
\end{tabular}




\section{6 .7$, COMPORTAMENTO}

Logo após a emergência, os adultos procuraram subir pela tela ou através das guarnições laterais, com o propósito de atingirem a parte superior da gaiola, onde ocorreu o processo de distensão das asas.

No processo de distensão alar, inicialmente, as asas expandiram-se ficando voltadas para o fundo da.gitola. Ao terminar este processo, que levou ao redor de 30 minutos, as a sas voltaram-se para o corpo recobrindo parte do abdome. Gradualmente, as asas posteriores e anteriores foram-se afastando do abdome, de tal maneira que as margens costais das asas ante riores chegaram a formar um ângulo de quase $90^{\circ} \mathrm{com}$ o tórax; as asas posteriores permaneceram debaixo das asas anteriores e quasē que totalmente escondidas. Nas asas posteriores, a parte exposta voltou-se para cima, ficando dessa forma, com um aspecto côncavo. Já nas asas anteriores cerca de um quarto da região anterior voltou-se para baixo, assumindo um aspecto de convexidade e dessa forma, as asas anteriores e posteriores ajustaram-se perfeitamente, uma sobre a outra. Todo esse processo de recurvamento levou cerca de 270 minutos, contados a partir da emergência.

No seu primeiro dia de fase adulta a fêmea per maneceu imóvel durante o dia, e os machos aproximaram-se das fêmeas, salvo algumas exceçōes, sem contudo tocá-las realizando pouquíssimos movimentos nesse periodo.

observou-se que individuos de ambos os sexos, mantiveram o abdome voltado para o lado direito ou para o lado 
esquerdo.

Ao cessar o período de luminosidade, os machos executaram movimentos circulares e desordenados com agitação bastante intensa das asas, porém sem executar vōos ao redor das fêmeas. Esses movimentos geralmente são realizados no lado oposto em que se encontram as fêmeas. As fēmeas raramente executam algum movimento.

A partir das 5:00 horas a movimentação dos adultos dentro das gaiolas, tornou-se bastante intensa, pois os machos começaram a realizar vōos agitados e desordenados, as fēmeas executaram alguns vōos, porém berm menos frequentes do que os machos. Esses vôos perduraram por cerca de uma hora com alguns intervalos de descanso.

Cessados os vōos, as fēmeas executaram vagarosamente movimentos circulares, com batidas de asas bem pausadas e finalmente parando com o abdome voltado para o macho. o ma cho,ao retornar às atividades, realizou alguns vōos agitados, chegando a bater com suas asas na asa da fémea, passando por cima dela alguma vezes. Após estes últimos vōos, as fêmeas expuseram parte da terminália genital, de coloração alaranjada . A seguir os individuos de ambos os sexos, permaneceram com os abdome voltados para o fundo da gaiola e aos poucos foram apro ximando-se de tal forma que as pontas do abdomes tocaram-se, $\underline{e}$ fetuando-se o acoplamento. Em alguns casos os machos soltaram- se da parte superior das gaiolas, ficando sustentados pelas fēmeas, em outros casos os machos mantiveram-se presos ao filó 
Observou-se também que quando os casais permaneceram nas guarnições o acoplamento deu-se de tal maneira que os abdomes fica ram em oposição.

Durante toda a cópula as fêmeas permaneceram imóveis e os machos, de vez em quando, executaram movimentos laterais bem suaves com os abdomes.

As cópulas iniciaram-se nas últimas horas do pe ríodo de escuridão, embora em alguns casos tenha sido iniciado nos primeiros minutos do período de luminosidade. A cópula prolongou-se durante o período de luminosidade.

$$
\text { Após a cópula a fēmea permaneceu praticamente }
$$

móvel até a postura; os machos repetiram as mesmas etapas do dia anterior, mas as fêmeas copuladas não foram receptivas.

Nas gaiolas com mais de um macho por fêmea observou-se que os machos executaram movimentos circulares, girando um próximo do outro até tocarem-se, na tentativa de expulsar um dos individuos da proximidade da fêmea. Algumas vezes os machos chegam a tocar na fêmea que permaneceu imóvel e em algumas delas chegaram a executar movimentos desordenados. 0 macho vencedor aproximou-se da fêmea mantendo esta posição até a cópula, enquanto que o outro permaneceu distanciado do casal. As fêmeas copularam uma ünica vez.

As fēmeas depositaram seus ovos preferencialmen te no filó das gaiolas e poucos ovos foram encontrados nas ar- i mações e fundos da gaiola, apenas uma vez foi detectado uma postura nas folhas de ipé oferecidas. As posturas iniciaram-se 
sob o período de escuridão e diversas vezes foram observadas fêmeas ovipositando durante o período de iluminação.

Próximos da morte, os adultos incapazes de se sustentarem no filó, permaneceram nos fundos das gaiolas. Alguㅡ mas horas antes da morte permaneceram com seus corpos volta dos para cima, chegando a executarem alguns movimentos com as pernas.

Não se observou o ritual de cópula dos adultos na alameda devido a interferência luminosa das lämpadas, que alterou o comportamento natural dos adultos devido ao fototropismo positivo.

Os adultos adotaram como mecanismos de defesa, quando tocados a excreção de um líquido bege-claro não cáustico e a seguir a imobilização geral do corpo, recolhendo as per nas e recurvando o abdome para baixo, simulando a morte.

\subsection{INIMIgOS NATURAIS}

Durante todo o ano foram coletados ovos parasitados na alameda e com bastante frequência. Os ovos parasita dos apresentaram uma coloração cinza-escura (Figura 25), sendo possivel observar os parasitos no interior dos ovos, um dia an tes das emergências. Os adultos desses parasitos foram enviados ao Dr. Norman F. Johnson (Ohio State University) que os identi ficou como sendo Telenomus sp., possivelmente espécie nova (Hymenoptera, Scelionidae) (Figuras 26 e 27). 
Constatou-se no campo e em laboratório a presen ça de um fungo associado às lagartas, pré-pupas e pupas. O material infectado foi enviado ao Dr. Sérgio Batista Alves (De partamento de Entomologia - ESALQ/USP), que identificou o fungo como verticillium sp.

O sintoma do fungo associado às lagartas caracterizou-se inicialmente pela formação de uma pequena constri ção anelar nos segmentos abdominais. Posteriormente, as lagartas tiveram sua atividade diminuida e no local da constrição surgiu um tecido necrosado de coloração negra e ao frutificar- se o fungo apresentou uma coloração branca. Embora a região de sintoma tenha sido localizada, preferencialmente, nos últimos segmentos abdominais, constatou-se também a presença do - sintoma nos primeiros segmentos abdominais (Figura 28). O fungo alastrou-se posteriormente pelo corpo todo das lagartas, apresentando um aspecto cotonoso. As pré-pupas e as pupas somen te apresentaram os sintomas quando, o fungo já havia frutifica do na região abdominal ou mesmo do tórax indiferentemente (Figura 29); esses indivíduos apresentaram-se com dimensões bem mais reduzidas do que os sadios.

Das pupas coletadas na alameda e trazidas para - laboratório, observou-se que em muitas delas apresentaram um pequeno orifício na porção abdominal e através do qual saiu um líquido de coloração bege variando de tonalidade clara à escura. Posteriormente, após o isolamento dessas pupas, constatou- 
- se a emergência de diversos adultos de moscas. Essas moscas foram enviadas ao Dr. José Henrique Guimarães (Museu de Zoologia da Universidade de São Paulo), que as identificou com Archytas lopesi Guimarães (Fig. 30) (Diptera, Tachinidae).

Em laboratório formigas Solenopsis sp. (Hymenop tera, Formicidae) atacaram ovos, pré-pupas e pupas de $R$. unimo da. 


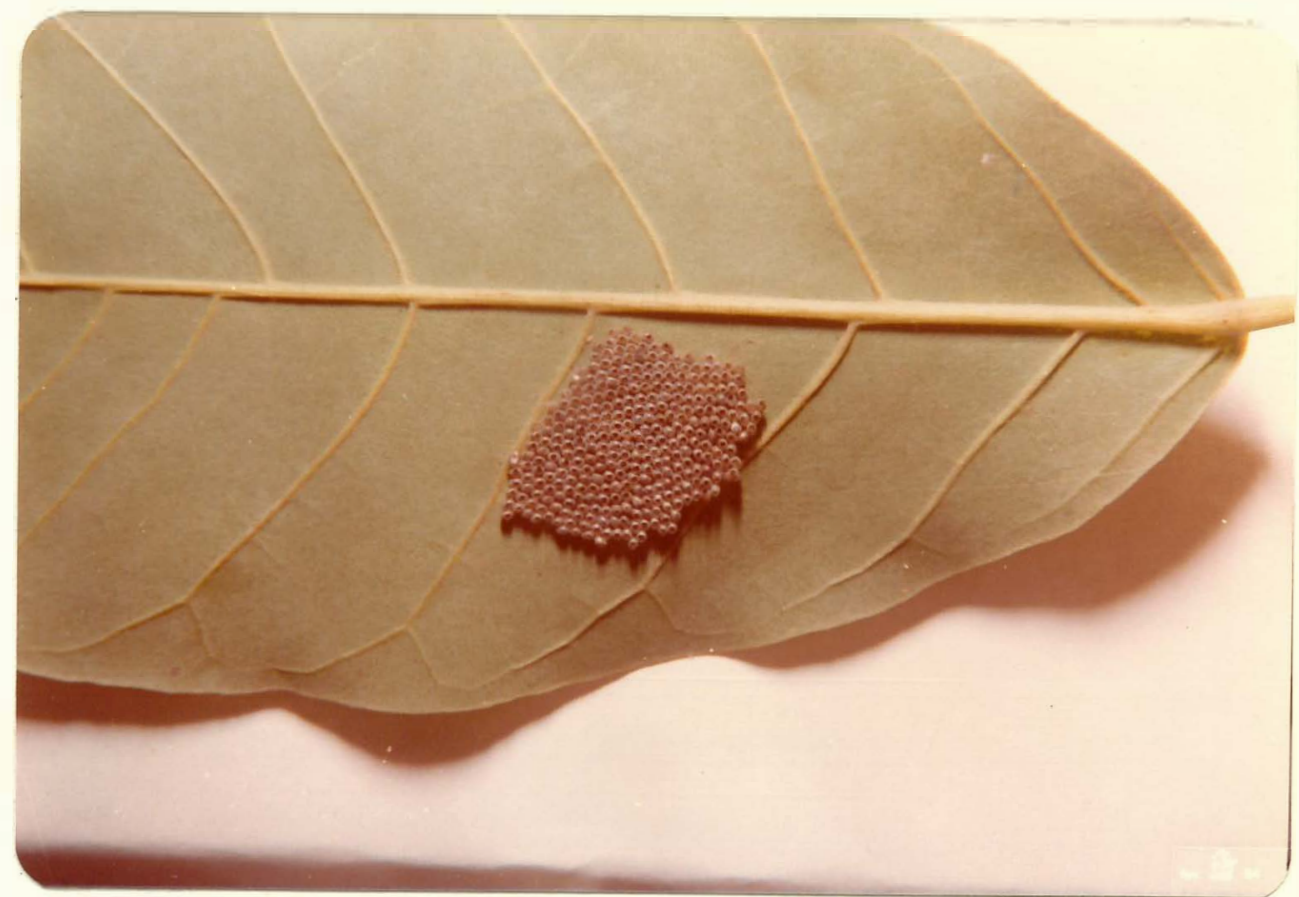

Figura 25 - Massa de ovos de R. unimoda, coletada na alameda e parasitada por Telenomus sp. (aumento 1,7X).

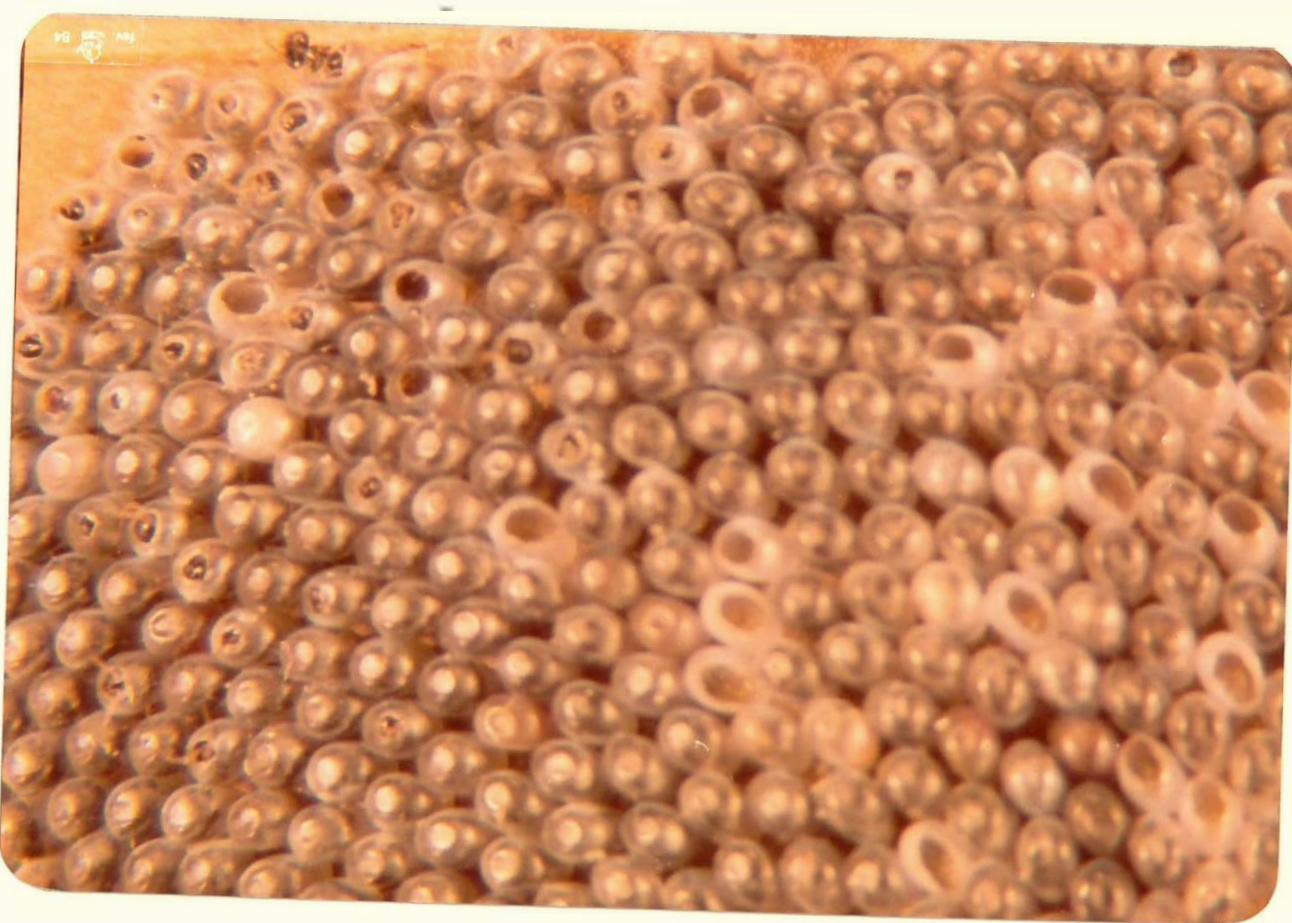

Figura 26 - Massa de ovos de R. unimoda, mostrando os parasitos Telenomus sp. no ato da emergēncia (aumento 12x). 


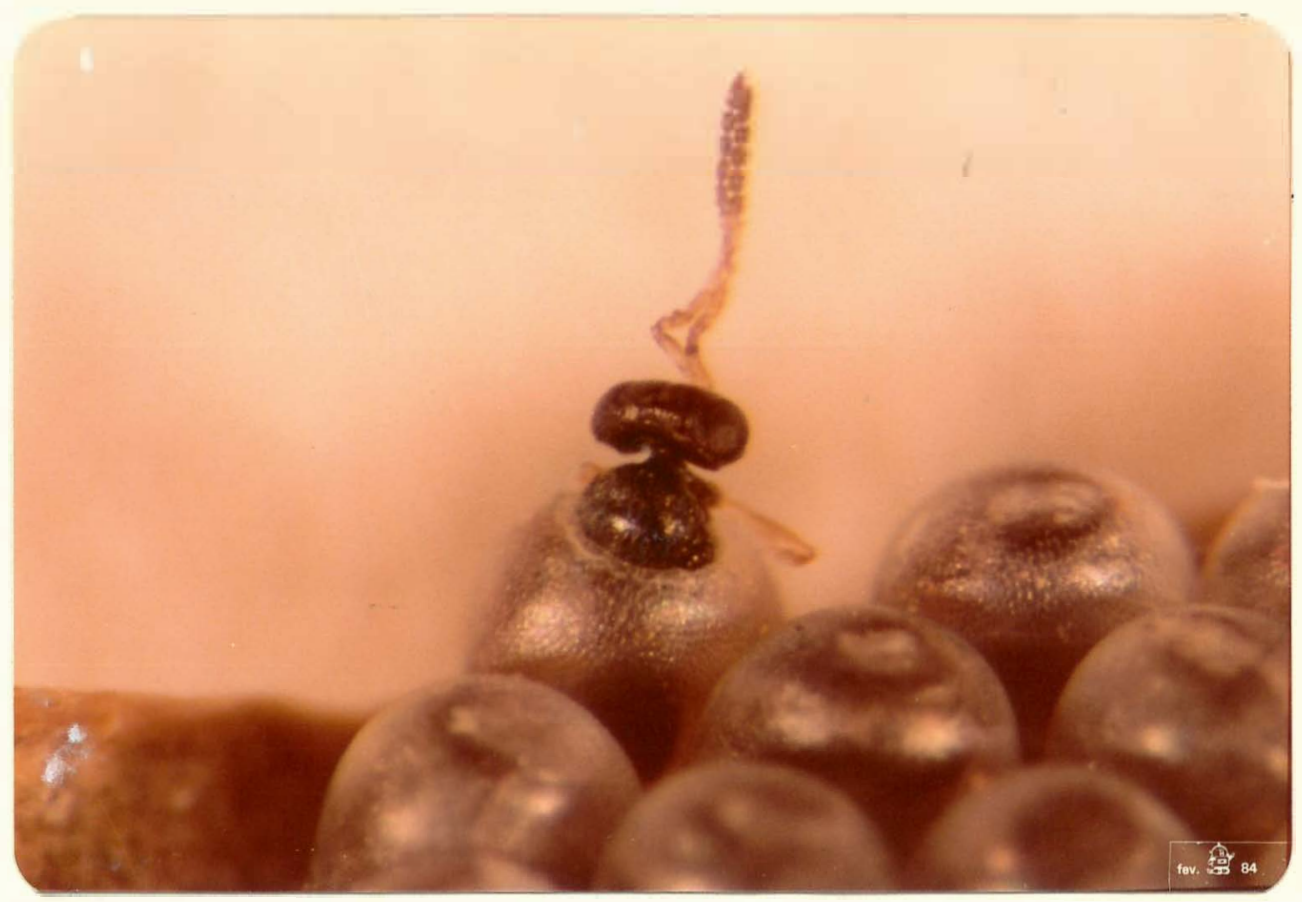

Figura 27 - Um parasito de ovos (Telenumus sp.) emergindo do ovo de R.unimuda (aumento de 50X).

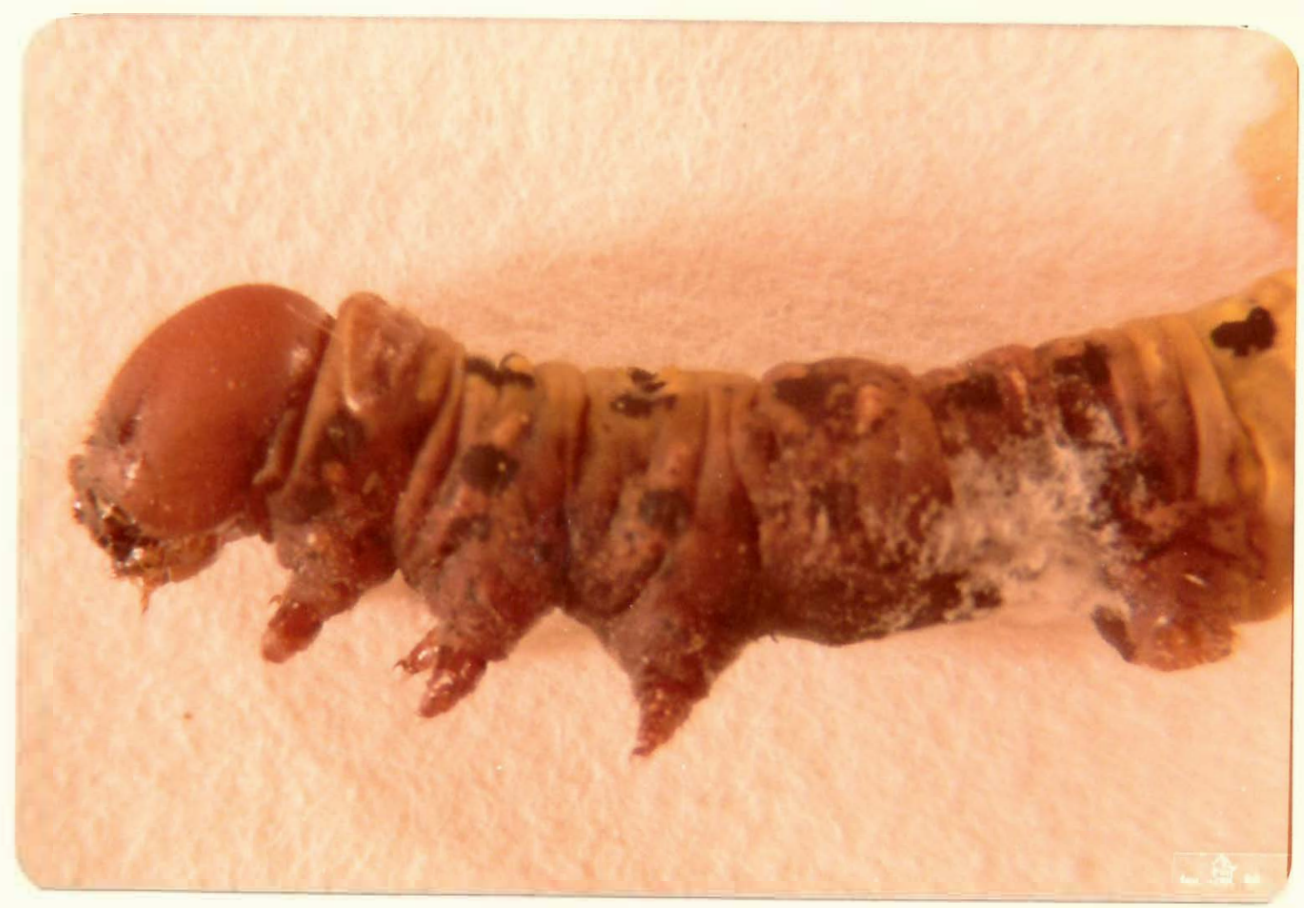

Figura 28 - Sintoma de ataque do fungo Verticillium sp. em uma lagarta de R.unimoda (aumento 12X), 


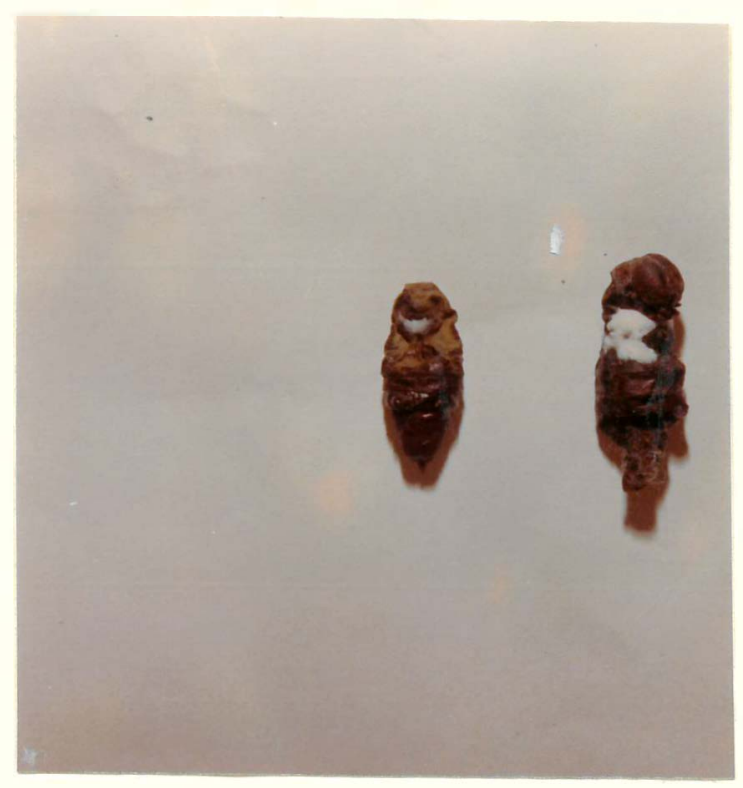

Figura 29 - Pupa (esquerda) e pré-pupa (direita) de R. unimoda, a tacadas pelo fungo verticillium sp. (tamanho natural).

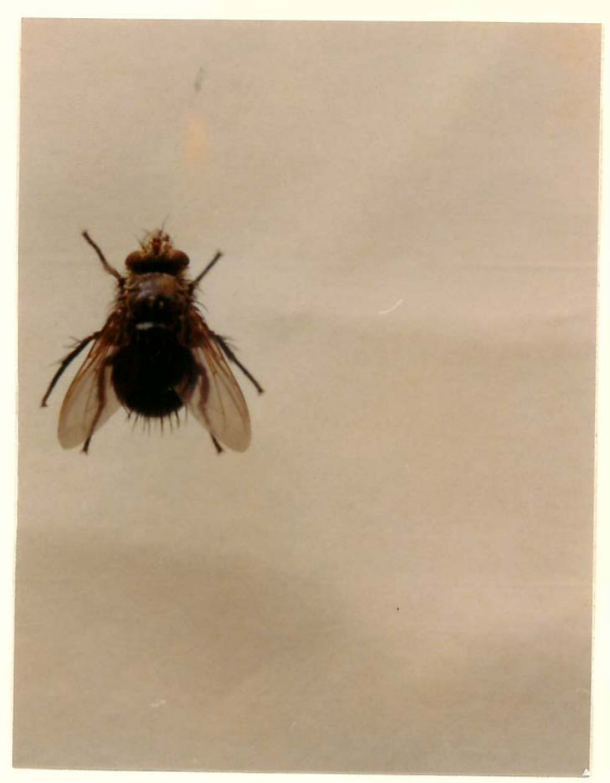

Figura 30 - Um taquinideo adul to, Archytas lopesi Guimarães parasito de lagar tas $^{-}$de $R$. unimoda (aumen to $1,2 \mathrm{x})$.

\subsection{NOME VULGAR}

Levando-se em consideração que R. unimoda foi encontrada associada ao ipē-rosa e ao paratudo, mas inicialmen te encontrada desfolhando o ipē e tambēm pelo maior conhecimen to e uso desta espécie arbórea, sugere-se que seja denominada vulgarmente por "lagarta do inē". 


\title{
5. CONCLUSÃO
}

\subsection{OCORRÊNCIA}

\begin{abstract}
R. unimoda ocorre em Cuiabá e Campo Grande, capitais dos Estados de Mato Grosso e Mato Grosso do Sul, respec tivamente.
\end{abstract}

\section{2. ÉPOCA DE OCORRÊNCIA}

O inseto ocorre o ano todo em diferentes fases, porēm a maior quantidade de lagartas é encontrada nos meses de chuvas, ou seja, de novembro a março e ainda no més de abril. 


\subsection{Ciclo eVolutivo}

a) Os ovos apresentam período médio de incubação igual a 5,5 dias e viabilidade média de 83,20, em laboratório. A viabilidade média no campo é de 84,00; para ovos parasitąos e inférteis é de 50,68 ;

b) As lagartas apresentaram seis, sete ou oito instares. As lagartas de seis instares apresentaram um periodo larval médio de 24,6 dias, para ambos os sexos; para as de sete instares 29,6 dias, para ambos os sexos; para as de oito instares as durações foram de 30 e 33 dias para o macho e fêmeas, res pectivamente. A viabilidade nessa fase é de 48\% e as maiores taxas de mortalidade são encontradas nos segundo e terceiro instares;

c) A fase de pré-pupa apresenta uma duração média de 1,94 dias e a viabilidade de 83,33\%;

d) A fase de pupa apresenta uma duração média de 21,1 dias, pạ ra ambos os sexos. A viabilidade nessa fase é de 90\%; 
e) Os adultos apresentam proporções sexuais de $1,70^{\circ}: 1,0 \%$; a longe vidade média para as fêmeas acasaladas e não acasaladas é de 5,6 dias e para os machos acasalados e não acasalados é de 4,6 dias.

\subsection{CaRActerizaç̃o das fases}

a) Os ovos recém-eclodidos são verde-limão com tonalidade clara e,à medida que vão amadurecendo, adquirem a coloração vinho-clara e antes da eclosão das lagartas são amarelo- palha. Em ambiente natural são encontradas na forma de placas e geralmente localizadas nas páginas inferiores das folhas de ipé e de paratudo;

b) As lagartas são gregárias no primeiro, segundo e terceiro Instares, mas neste último Instar começa notar-se a disper são dos indivíduos. A alimentação dá-se durante o dia e a noite porém, mais intensamente durante o dia;

c) As lagartas podem ser separadas a cada instar, através do conjunto de caracteristicas, tais como: coloração das verrugas, presença das manchas ao redor das verrugas, mudanças de cor e tonalidade geral do corpo e atrofiamento da grande ver ruga do oitavo segmento dorsal do abdome (VIII instar); 
d) O consumo foliar médio das lagartas de seis e sete instares é de $275,34 \mathrm{~cm}^{2}$, para as folhas de $T$. avellanedae com o último Instar bem mais voraz do que os demais. As fémeas apre sentam uma tendēncia para consumirem uma área foliar maior do que os machos;

e) A razão de crescimento das cápsulas cefálicas, cresce em pro gressão geométrica de um instar para outro e de acordo com a regra de DYAR;

f) Em ambiente natural as pré-pupas e pupas são localizadas dẹ baixo das folhas no solo;

g) As dimensões como largura, comprimento e o peso apresentam valores maiores, para as pupas que originarão as fêmeas adultas quando comparadas, com as pupas que originarão os ma chos adultos;

h) A emergéncia dos adultos dā-se no intervalo das 09:00 até às 20:00 horas. Os machos apresentam como característica marcante um tufo de escamas piliformes na porção dorso - terminal do abdome, que os distinguem seguramente das fêmeas;

i) o período de pré-cópula ocorre de um a trēs dias após a emergência. A fêmea copula um só vez e quando há a presença de mais de um macho por fêmea, ocorre a competição pela fémea. Sob condiçōes de laboratório, o não acasalamento é sen 
sivelmente reduzido quando se deixa penetrar neste ambiente a luminosidade natural. As cóoulas iniciam predominantemente no período de escuridão, mas em alguns indivíduos iniciam-se nos primeiros momentos de luminosidade; as cópulas ocorrem a partir das 05:00 horas e vão até às 22:09 horas e com uma duração média de 716,0 minutos;

j) A maioria das fémeas realiza uma postura, embora algumas cheguem a efetuar até quatro posturas; colocam a maioria dos ovos na primeira postura e diminuem gradativamente nas posteriores. No laboratório, as fēmeas iniciam suas posturas no período de escuridão e continuam mesmo no período de luminosidade; a quantidade média de ovos por fémea é igual a 296,$1 ;$

I) Os adultos não se alimentam, por não apresentarem espirotromba desenvolvida.

\subsection{INIMIGOS NATURAIS}

Os inimigos naturais de R. unimoda são: Telenomus sp. (Hymenoptera, Scelionidae), provavelmente espécie nova (parasito de ovos) e Archytas lopesi (Diptera, Tachinidae) (pa 
rasitos de lagartas).

Em laboratório, o principal inimigo das lagartas, pré-pupas e pupas é o fungo entomógeno verticillium sp., que chega a ser um sério problema para a criação das lagartas. 
.111.

\section{LITERATURA CITADA}

BERTI FILHO, E., 1981. Insetos associados a plantações de espécies do gênero Eucalyptus nos Estados da Bahia, Espirito Santo, Mato Grosso do Sul, Minas Gerais e São Paulo. Piracicaba, ESALQ/USP, 176 p. (Tese de Livre Docência).

CORREA, M. P., 1931. Dicionário das plantas úteis do Brasil e das Exóticas. Rio de Janeiro, Empresa Gráfica Gutemberg, $\mathrm{v} .2,707 \mathrm{p}$.

CORREA, M. P., 1969. Dicionário das plantas úteis do Brasile das Exóticas. Rio de Janeiro, Irmãos Di Giorgio, v.4, 765 p.

DOGNIN, P., 1923. Heteroceres nouveaux de I'Amérique du Sua. Rennes, Oberthdr., V. 21, p. 1-38. 
DYAR, H. G., 1902. A list of North American Lepidoptera and Key to the Literature of this Order of Insects. Washington D. C.; United States National Museum, 723 p. (Bulletin, 52).

FLINTA, C. M., 1977. Práticas de Plantación Florestal en América Latina., 3ạ ed., Roma, FAO, 499 p.

GALLO, D.; O. NAKANO; S. SILVEIRA NETO; R. P. L. CARVALHO; G. C. BATISTA; E. BERTI FILHO; J. R. P. PARRA; R. A. ZUCHI e S. B. ALVES, 1978. Manual de Entomologia Agrícola.- São Paulo, Ed. Agronômica Ceres, 531 p.

MELLO Fo, L. E. de, 1983. Vegetação e Espaço Urbano. A Lavoura. Rio de Janeiro, 85: 30-35, mar/abr.

RATTER, J. A; P. W. RICHARDS; G. ARGENT e D. R. GIFFORD, 1973. Observations on the vegetation of northeasten Mato Grosso. I. The woody vegetation types of the Xavantina-Cachimbo Expedition area. Philosophical Transactions of the Royal Society of London. Cambridge, 266 (880): 449-492.

RIZZINI, C. T., 1971. Árvores e Madeiras Úteis do Brasil - Manual de Dendrologia Brasileira. São Paulo, Editora Edgard Blächer, 294 p. 
SCHAUS, W., 1927. Lymantriidae. In: Seitz, A. Die Gross-Schmetterlinge der Erde. v.6, p.535-564.

SILVA. A.G.A.; C.R. GONÇALVES; D. M. GALVÃO; A.J.L. GONÇALVEZ;

J. GOMES; M. N. SILVA e L. SIMONI, 1968. Quarto catálogo

dos insetos que vivem nas plantas do Brasil: seus parasitos

e predadores. Rio de Janeiro. Ministério da Agricultura, 4 v. 